\title{
Managing the Lower Mississippi River Landscape for Strategic Navigational and Flood Control
}

\author{
Kenneth R. Olson', David R. Speidel² \\ ${ }^{1}$ Soil Science in the College of Agricultural, Consumer, and Environmental Sciences, University of Illinois, Urbana, Illinois, USA \\ ${ }^{2}$ USDA Resource Conservationist and Agricultural Consultant with Natural Resource Conservation Service and Foreign \\ Agricultural Service, Benton, Missouri, USA \\ Email: krolson@illinois.edu
}

How to cite this paper: Olson, K.R. and Speidel, D.R. (2021) Managing the Lower Mississippi River Landscape for Strategic Navigational and Flood Control. Open Journal of Soil Science, 11, 285-330. https://doi.org/10.4236/ojss.2021.116016

Received: May 7, 2021

Accepted: June 1, 2021

Published: June 4, 2021

Copyright $\odot 2021$ by author(s) and Scientific Research Publishing Inc. This work is licensed under the Creative Commons Attribution International License (CC BY 4.0).

http://creativecommons.org/licenses/by/4.0/

\begin{abstract}
The Lower Mississippi River flows from the confluence of the Ohio River and Mississippi River at Cairo, Illinois into the Gulf of Mexico. Mississippi River and Ohio River pathway shifts have shaped and re-shaped the landscapes through which they flow and where their sediment-laden tributary waters co-mingle at the confluence on the voyage to the Gulf of Mexico. For much of their history, the lands adjacent to the Lower Mississippi River were bottomlands that flooded with the seasons unconstrained by human river training structures. Since 1717 European nations have fought over strategic navigational control of the Mississippi River. After the Louisiana Purchase in 1803, the United States took controlled the Lower Mississippi River. During the Civil War, from 1861-1865, the Union and Confederate forces battled for navigational control of the Lower Mississippi River. The primary objective of this paper was to highlight how the strategic navigational and flooding control of the Lower Mississippi River and geological and landscape resources were responsible for the successful economic development of this rich historical region of North America.
\end{abstract}

\section{Keywords}

Atchafalaya, Bonnie Carre Spillway, Floodways, Morganza Floodway, Water Storage Areas, West Atchafalaya Floodway, Civil War, Gunboats, Mound City, Cairo, Illinois, Slaves

\section{Introduction-Early European Settlement and Management of the Lower Mississippi River Landscapes}

The French established a claim to Louisiana and New Orleans in 1717. By 1721 
the French built a wooden lighthouse-type structure in New Orleans. In 1762, France ceded Louisiana to Spain. From 1700 to 1888 main navigation channel changed location four times as a result of shifting sand bars, mudflats and hurricanes.

To give the United States Army Corps of Engineers (USACE) the authority to remove sand bars on the Ohio River and snags on the Mississippi River, Congress passed an "Act to Improve the Navigation of the Ohio and Mississippi Rivers." The General Survey Act of 1824 authorized the use of USACE to survey roads and canal routes. The 1824 act to improve navigation on the Mississippi and Ohio rivers has often been called the first harbors and rivers legislation. The act passed in 1826 was the first to combine authorizations for both projects and surveys [1].

Slaves seeking freedom in the early 1800 s often found their way across the Mississippi and Ohio rivers and then moved north along either the Mississippi River to Galena, Illinois, along the Illinois River to Chicago or along the Wabash River to the Northeastern United States.

At the start of the American Civil War in 1861, Cairo, Illinois became an enormous Union military camp (Figure 1). The Ohio River was contested during the Civil War. The required supplies for the Union army had to be re-routed from

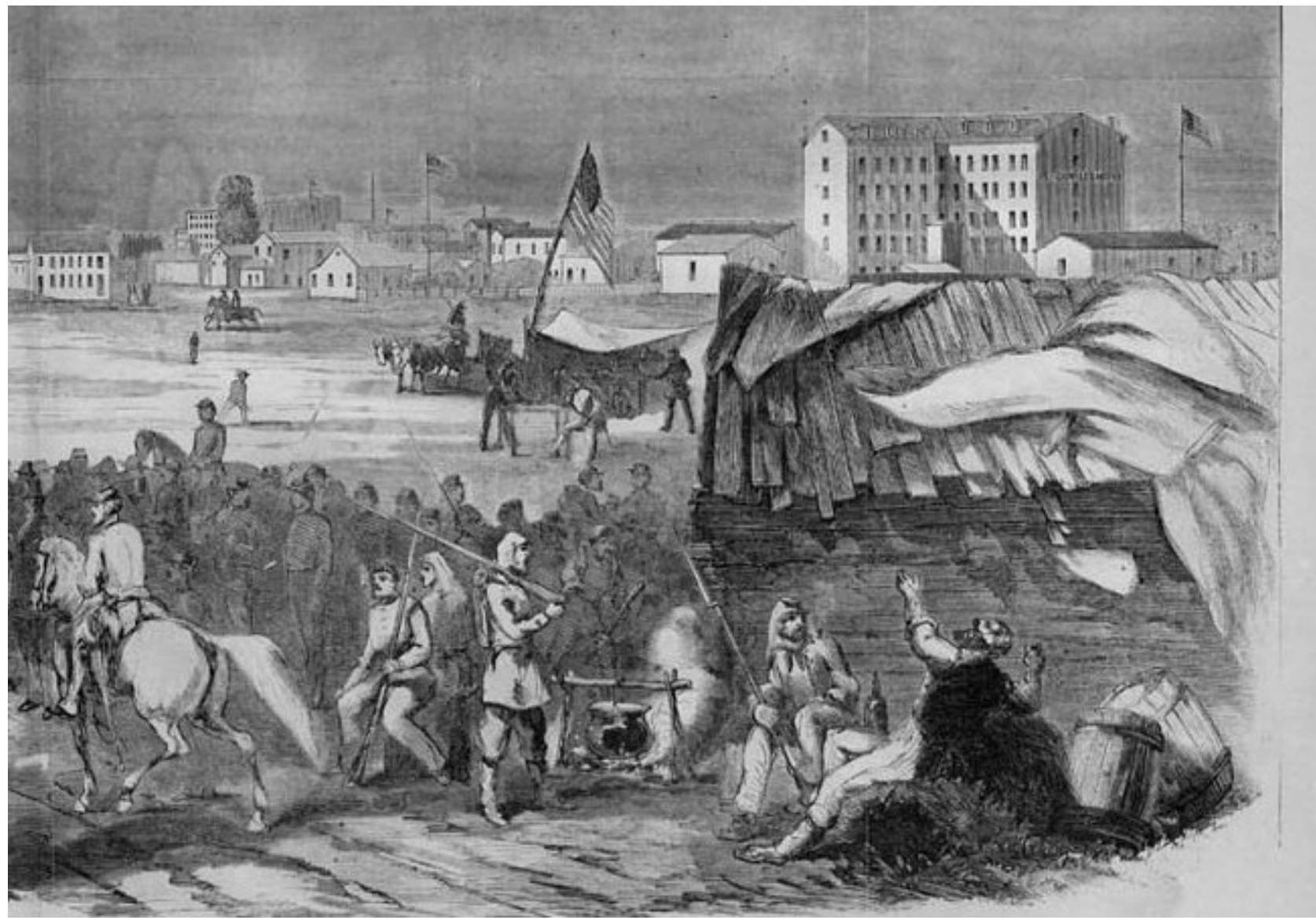

Figure 1. Drawing of Union military base and hotel (the 5 story structure in upper right hand corner) in Cairo, Illinois in 1861. 
the Ohio River to the Great Lakes, via a dredged canal [2], and Illinois River to the Upper Mississippi River. Union gunboats were built by James Eads on the Ohio River in the early 1860s at Marine Ways, Mound City, Illinois. These gunboats permitted the rapid advance of thousands of Union soldiers on the Lower Mississippi, Cumberland, Ohio and Tennessee rivers and allowed the Union Forces to out-maneuver the Confederate Army and Navy.

In 1879 the Mississippi River Commission (MRC) was created by Congress to maintain and control the Mississippi River and tributaries [1]. The federally funded MRC was responsible for maintaining navigational control of the Mississippi River. The MRC and USACE sought to make the Mississippi River more navigable by deepening the river and making it less likely to flood. In 1885, USACE adopted a "levees-only" policy. During the next 40 years, the USACE extended the levees system which resulted in the sealing of many of the river's natural tributary inlets and outlets. In 1885, the first complete Ohio River lock and dam project was built by USACE [2]. In 1910 Congress passed the Rivers and Harbors Act. By 1926, levees extended from Cairo, Illinois to the Gulf of Mexico. All Mississippi River bottomlands from the Gulf of Mexico to the confluence of the Mississippi and Ohio rivers had levees. Many of these federal levees failed during the Flood of 1927 and resulted in the death of 800 people. The disaster alerted Congress of the need to modify the MRC/USACE "levees only" policy.

The primary objectives of this paper are to highlight how the strategic navigational and flooding control of the Lower Mississippi River and geological and landscape resources were responsible for the successful economic development of this rich historical region of North America.

\section{Location}

\subsection{Ancient Mississippi and Ohio Rivers}

The Mississippi and Ohio rivers and their adjacent landscapes have a long and dramatic geological history stretching back billions of years. Shifts in the earth's crust, tectonic activity, and rising and falling sea levels altered landforms and river flows. More recently in the geological time scale of the earth (2.6 million years ago to present) was the glaciation of the North America Hemisphere and a period of rapid climate fluctuations with advances of ice sheets alternating with warmer interglacial periods [3]. As a result, fluctuations in meltwater flowing southward into the Gulf of Mexico repeatedly rerouted the ancient Mississippi and Ohio River channels [4] as glaciers advanced during colder climatic periods and retreated in warmer intervals.

\subsection{The Mississippi Embayment and New Madrid Fault Zone}

The confluence of the Ohio and Mississippi rivers (start of the Lower Mississippi River) was the northern-most apex of the ancient gulf coast sea (Figure 2) and the Mississippi Embayment [4]. This embayment is a north-south structural basin between the Ozark Plateaus in the west and Appalachian Highlands in the 


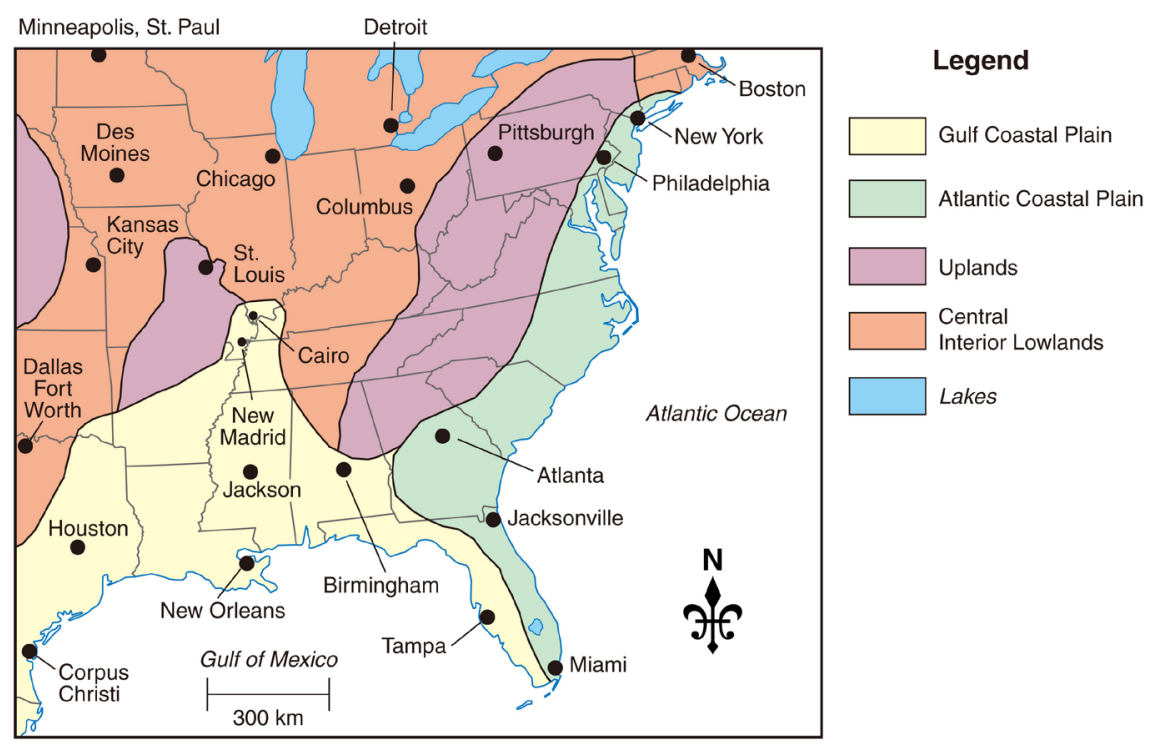

Figure 2. Ancient sea lowlands. Published with copyright permission from Book Editor of Soil and Water Conservation Society. Map by Mic Greenberg.

east created by down warping and down faulting [5] [6] as consequence of tectonic plate drifting of the Mississippi Valley in the Late Cretaceous period [7]. A system of faults run parallel to the axis of the Mississippi Embayment trough and underlies modern-day southeast Missouri and northeastern Arkansas. This area was an active fault zone associated with the New Madrid (Missouri) earthquakes in 1450-1470 CE and 1811-1812 CE. New Madrid has been the center of seismic activity for thousands of years and was once at the edge of the ancient sea (Figure 2). Seismic activity re-routed the Mississippi and the Ohio rivers [4] as the land rebounded by as much as $4 \mathrm{~m}$ in 1000 years following the glacial periods. Earthquakes in the New Madrid seismic zone are thought to have occurred as early as the Precambrian Era at depths ranging from 4 to $13 \mathrm{~km}$ under the Mississippi Embayment [7].

The upland bluffs of Crowley's Ridge (Stoddard County, Missouri) and Benton Hills (Scott County, Missouri) reveal fluvial sands and gravels about $12 \mathrm{~m}$ thick overlain with loess consisting of windblown silt as deep as $34 \mathrm{~m}$ [7]. Fluctuations in upstream glacial meltwater discharge and downstream sea levels influenced the historic Mississippi River channel incisions and the many braid belts (channels) running on both sides of Crowley's Ridge (Figure 3) in Missouri and Arkansas [8] [9].

\subsection{Geological History of Mississippi River Valley South of Cairo}

The rapid abandonment of old river channels and the creation of new channels are evident throughout the Lower Mississippi River valley (Figure 4). Fluctuations in glacial meltwater and sediment deposition during warming intervals affected river channel slopes led to these avulsions. Channel slopes are reduced and become unstable when the river carried more sediment than the water could 


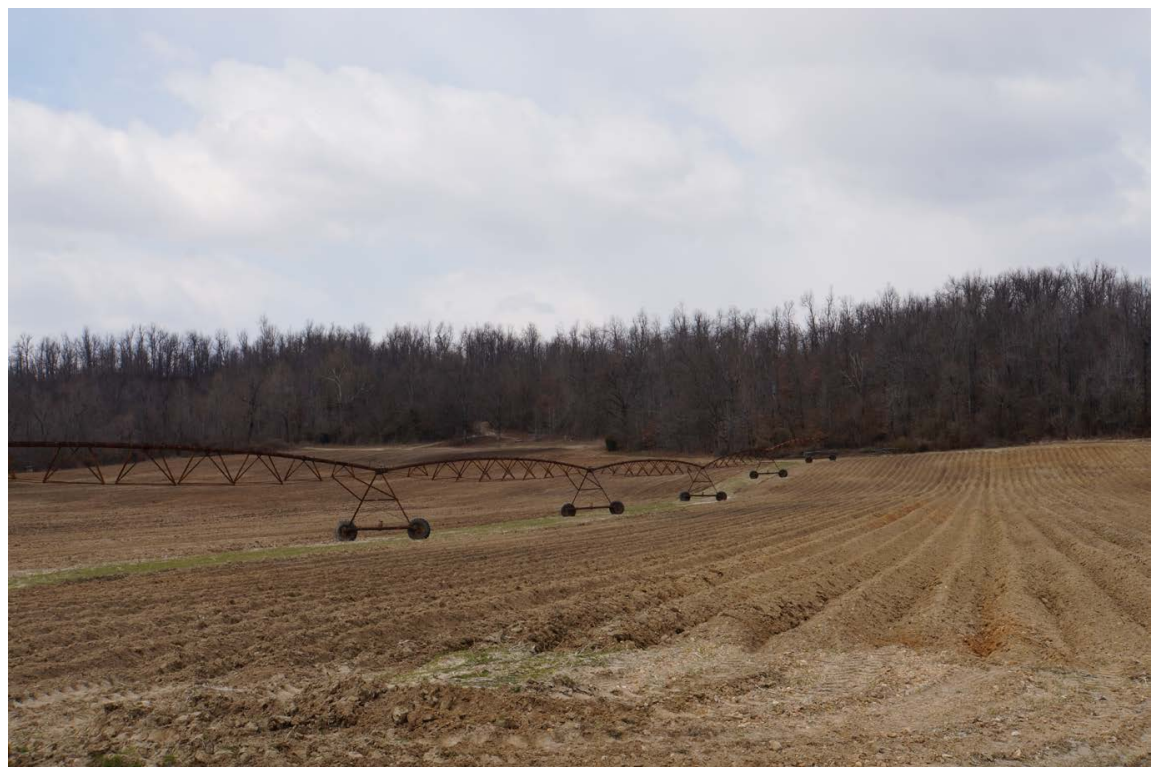

Figure 3. Irrigated agricultural lands at the base of the forest covered Crowley Ridge. Published with copyright permission from Book Editor of Soil and Water Conservation Society. Photograph taken by Lois Wright Morton.

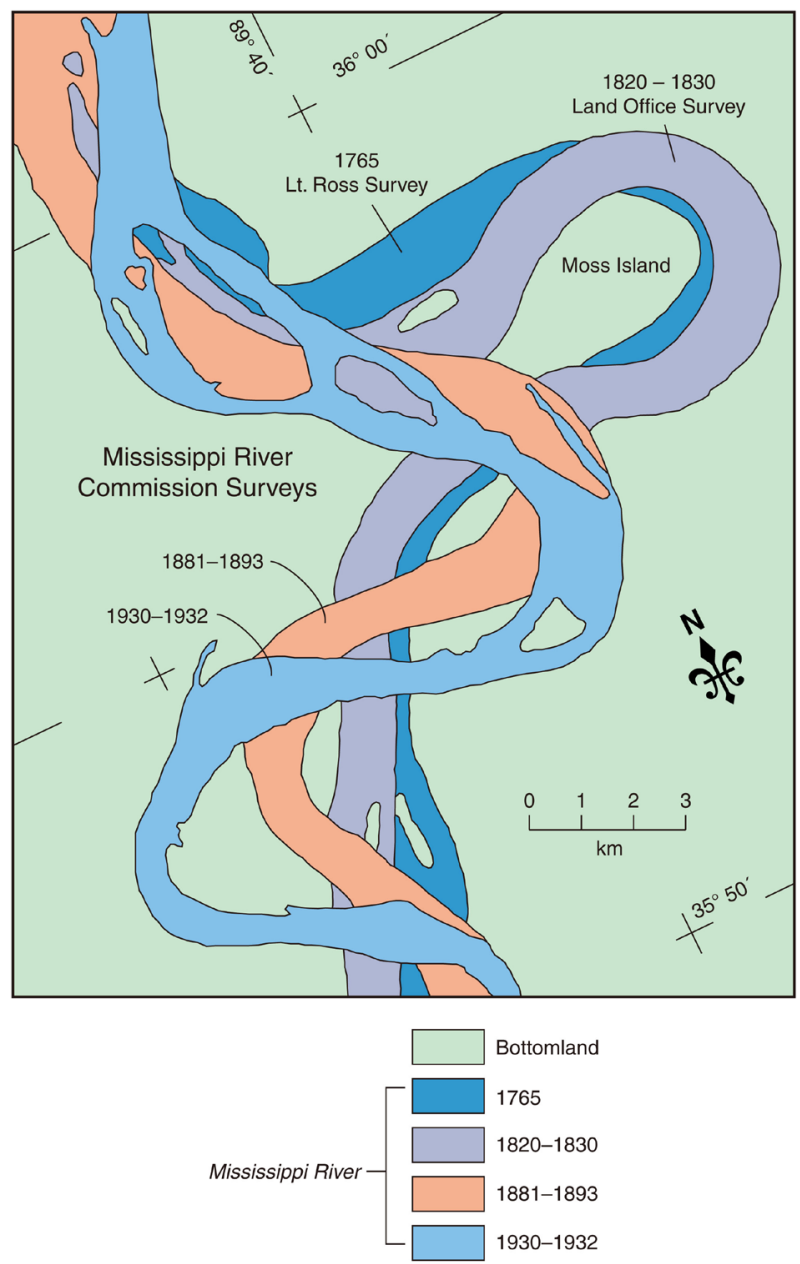

Figure 4. Oxbow and meander channels at Moss Island. Map by Mic Greenberg. 
transport. With an increase in sediment deposits, the river bed becomes higher than the floodplain; and became easier for the river to breach its natural levees. Breaching, which occurred during flood events, caused the river to spill out of its old channel and create newer ones as the water sought more stable slopes and shorter routes downstream.

Historically the Mississippi River has entered the Lower Mississippi River valley through three channel paths: 1) an opening cut between the Ozark Plateau and the northern end of Crowley's Ridge [8];2) the $16 \mathrm{~km}$ wide break between the northern end of Crowley's Ridge and Benton Hills; and 3) the Thebes Gap through which the current Upper Mississippi River flows [9] [10]. The Mississippi River originally turned west at Cape Girardeau and occupied the Western Lowland between the Ozark Highlands and Crowley's Ridge. The Ozark Escarpment was the west bank of the Mississippi River. The Ohio River flowed south along the eastern edge of Crowley's Ridge and occupied the Eastern Lowland south of Scott County Hills. At that time, Crowley's Ridge and Scott County Hills were a continuous upland and formed the divide between the Mississippi and Ohio rivers. The junction of the two large rivers was near Helena, Arkansas.

Later, the Mississippi River changed course and cut through Crowley's Ridge, forming a large gap in the upland soils between Bell City and Oran, Missouri called the Benton Hills gap. At the time, the Sikeston Ridge and Kennett Ridge were linked. Then, the Mississippi River shifted again to occupy Thebes Gap, a gorge north of Commerce, Missouri, and joined the Ohio River near Cairo, Illinois. The combined rivers follow a meandering course south to Arkansas state line and eventually flowed to the Gulf of Mexico.

The Mississippi River changed course at the end of the Great Ice Age. Prior to this, southeast Missouri and southern Illinois were engulfed in a shallow sea (Figure 2) until the waters receded and regional elevation rose at the end of the Pennsylvanian period. After the last glacier advance, the melting ice waters flooded and altered the course of many streams and channels including the ancient Ohio and ancient Mississippi rivers. With the change in the ancient Ohio and ancient Mississippi river paths, the location of their confluence also shifted. The confluence (Figure 5) had been located in Malden, Missouri; Morley, Missouri and now at Cairo, Illinois [8]. Historically, this region has been a delta, confluence and bottomlands dating back 30,000 to 800,000 years BCE.

\subsection{Mississippi and Ohio River Landscapes}

The Mississippi and Ohio rivers converge at the northern edge of an ancient sea and lowlands of the Mississippi Embayment. A land bridge separates the Central Interior Lowlands from the Gulf Coastal Plain (Figure 6). This upland land bridge, the Shawnee and Ozark Hills, connects the Southern Appalachians and the Ozark Highlands [8]. Plants and animals used this land bridge (Figure 6) to migrate between the Southern Appalachians and the Ozark Highlands. The ancient Ohio and Mississippi rivers are overlain on the land bridge to help the reader 


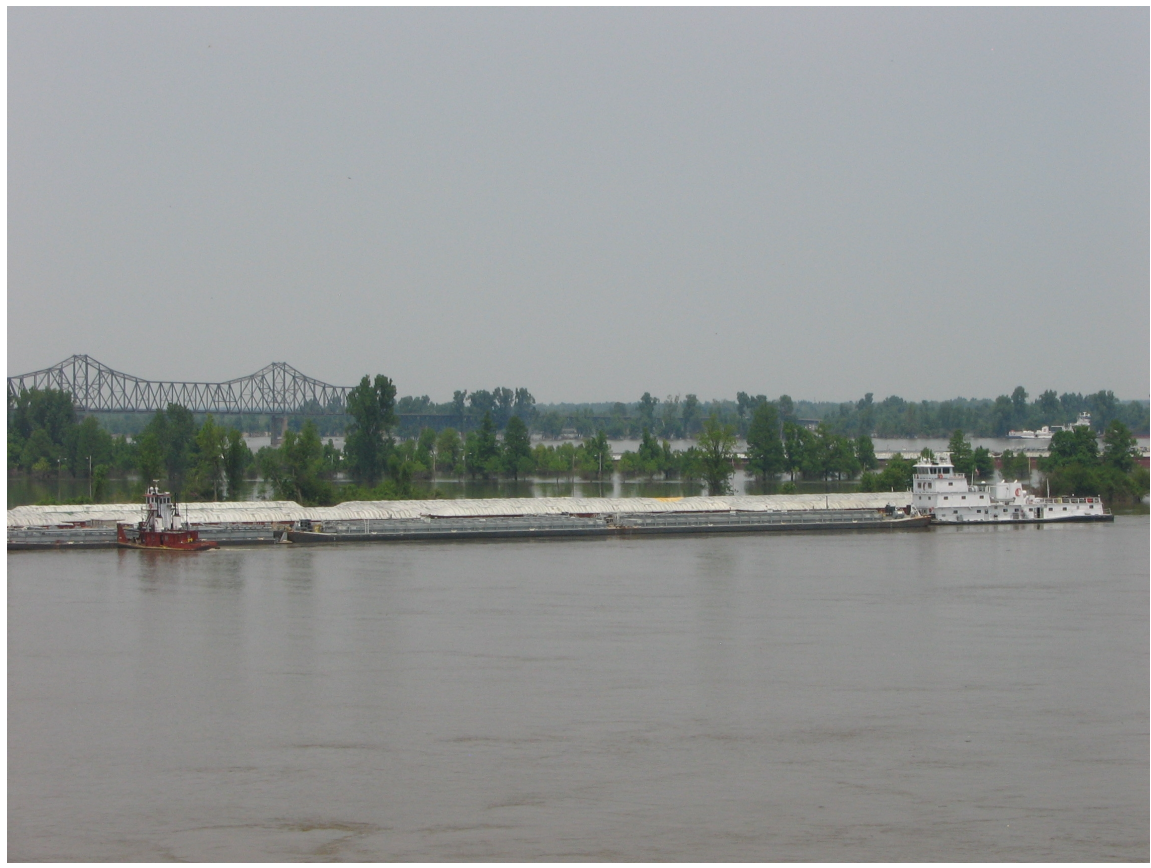

Figure 5. Flooded confluence of the Mississippi and Ohio rivers. Published with copyright permission from Book Editor of Soil and Water Conservation Society.

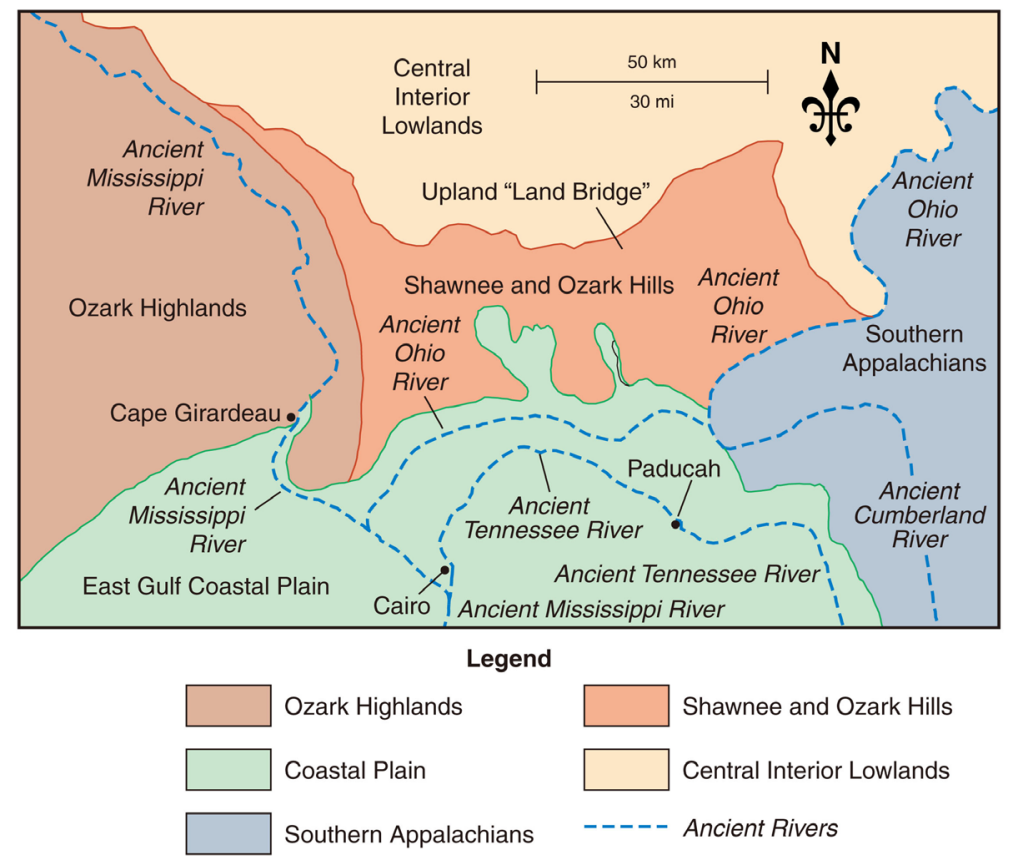

Figure 6. Upland land bridge and ancient river locations. Published with copyright permission from Book Editor of Soil and Water Conservation Society. Map by Mic Greenberg.

visualize its location [11]. The Ozark Highlands including the Francois Mountains (Figure 7) were created by volcanic and intrusive activity approximately 1.5 billion years ago [12]. By comparison, the Appalachian Mountains began forming about 460 million years ago [11]. 


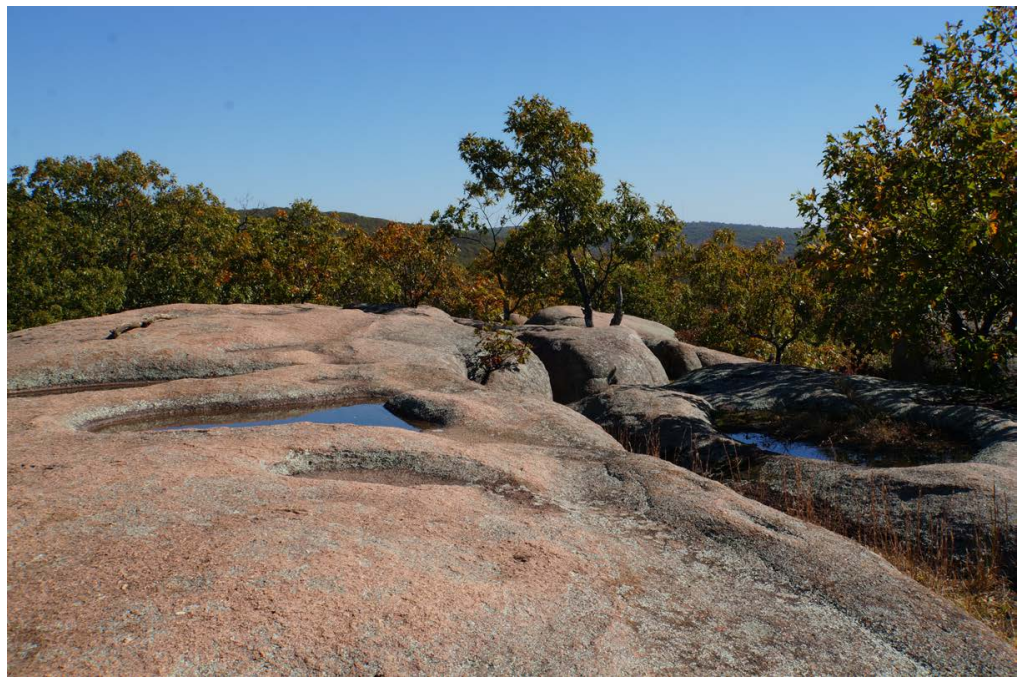

Figure 7. Elephant Rock Park in the Francois Mountains. Photograph taken by Lois Wright Morton.

The ancient rivers, gulf coastal inland sea, and land bridge map of the Central Interior Lowlands affected the pathways and confluences the current great rivers and their tributaries. Melting glaciers as a result of a changing climate and seismic activity re-aligned the Ohio and Mississippi rivers over time. With the settling of the Midwest, the locations of these great rivers were often used as state boundaries and the size and shape of many states were affected by the geological events which formed and reformed these rivers [4] [13].

\section{Strategic Navigational Control of the Mississippi River}

The first attempt to control the Mississippi and tributary landscapes occurred in 1717. New Orleans, a deep water port, was established by the French on the Mississippi River $80 \mathrm{~km}$ up river from the Gulf of Mexico. The original city settlement site had an area of 14 city blocks with drainage ditches around each block and was the first strategic attempt to control the landscape. In 1718 the first levee may have been erected on banks of the Mississippi River but was never confirmed. The French documented levees were built in 1722 . These levees were 1.2 $\mathrm{m}$ high earthen mounds began a 300-year history of combating high water with embankments in an attempt to control flooding [4]. The levees were sustained by private landowners, who used state slaves, prisoners, and poverty stricken Irish immigrants to perform the dangerous work. New Orleans had poorly-drained soils, unfavorable topography, and was only a few feet above the sea. The deltaic floodplain of the Mississippi River had a settling at a rate of between 0.6 to $3 \mathrm{~m}$ per century. Settlement on the Mississippi River Delta was prone to periodic flooding by the river.

\subsection{Early European Settlement}

More than two million people call the Mississippi River Delta their home (Figure 8). The Delta location at the mouth of the Mississippi River allowed the 


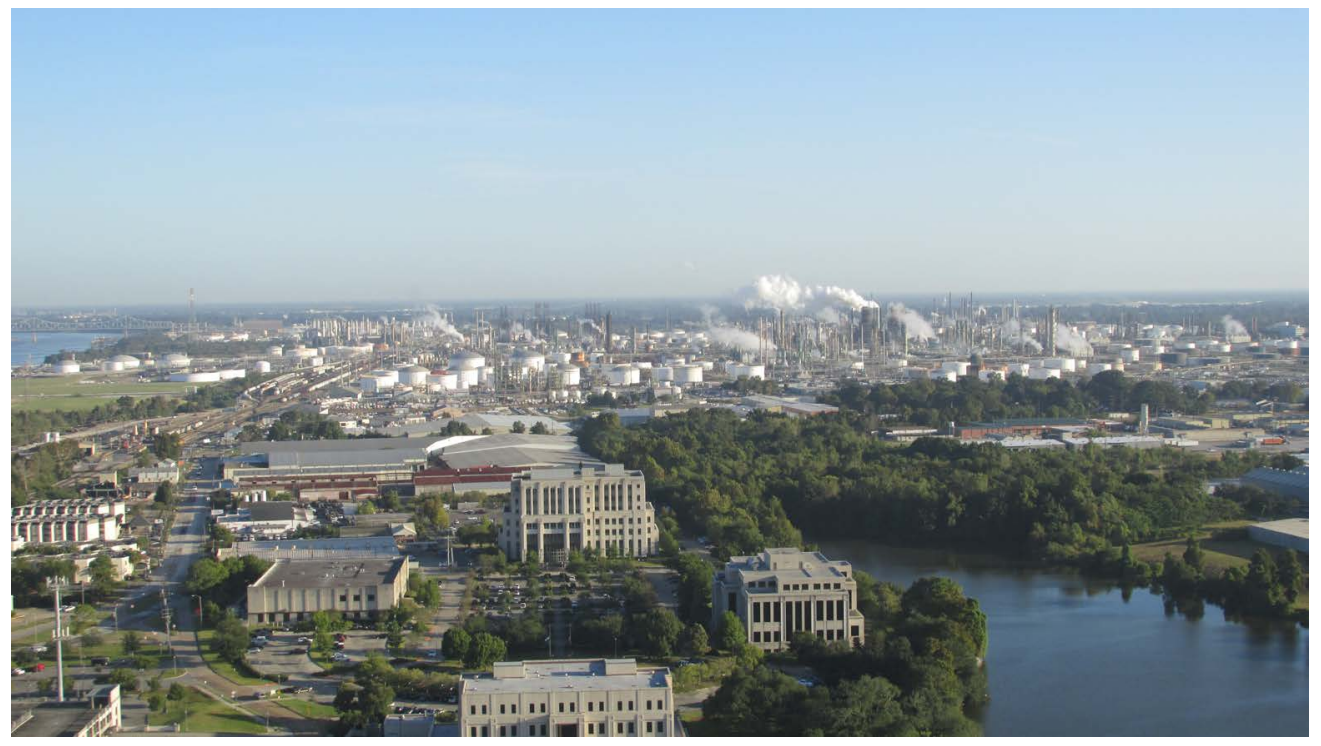

Figure 8. Mississippi River Delta has a population of 2 million with large chemical and energy facilities. Photograph taken by Lois Wright Morton.

area to be the Gateway to the United States and the Gulf of Mexico [14]. The location resulted in the mix of nationalities and created a diverse region. Louisiana's first $18^{\text {th }}$ century colonists were the French who were later joined by the Acadian and Spanish settlers. By the $19^{\text {th }}$ century, European immigrant ethnic groups, the African, West Indians and Native American were in the mix. Two unique groups were Creoles and Cajuns. Creoles refer to a black, white, or mixed-race native of Louisiana [15]. Before 1803 the Creole populations were typically born of Spanish and/or French parents who kept their European cultures and characteristics.

Many early Acadians who came from the Centre-Quest region of France left for the new world in 1600s to escape from excessive taxation under feudal overlords, famine, disease, drought, and religious warfare. The Acadians settled in Acadia, the present-day Maritime Provinces of Canada [15], which they called their new home. They lived in Acadia for over 100 years on the frontier as hunters, farmers, fishermen and fur trappers. In 1710 the British seized Acadia and renamed it Nova Scotia (New Scotland). After 45 years the British used force to expel the Acadian population. Prior to the 1755 expulsion it is estimated that 15,000 to 18,000 Acadians lived in Nova Scotia. As many as 10,000 died from neglect, starvation, disease, exposure and violence at the hands of the British [16]. Of the survivors, about 3000 exiles made their way between 1764 and 1788 to Spanish-held Louisiana. As buffers against British encroachment Spanish administrators wanted non-English settlers.

In 1762 France choose to cede to Spain the unprofitable colony, including Bayou Teche. The France government offered their colonial officers large land grants in lieu of a costly return trip to Europe. These officers brought in a herd of semidomesticated Spanish longhorn cattle to be managed by 200 French-speaking Acadians exiles. Many of these exiles and their offspring began to intermarry with 
other ethnic groups which evolved into the Cajuns, a vital new ethic group.

\subsection{Bayou Teche}

The Bayou Teche begins in Port Barre and flows southward to the Lower Atchafalaya River (Figure 9) and was the primary means of transportation during the Acadian migration. The Bayou Teche is a $200 \mathrm{~km}$ long waterway in south central Louisiana. Bayou Teche was the Mississippi River's main stem when it developed a Delta segment about 2800 to 4500 years ago. The Mississippi River's deposits of sediment and silt caused the river course to change every thousand years (Figure 10). This natural process is called deltaic switching.

Bayou Teche is a Mississippi River channel carved out approximately 3800 to 5500 years ago. The Red River occupied the channel when the Mississippi River moved east. The Red River (Figure 9 and Figure 11) was intercepted by the Mississippi River (stream capturing) [17] about 2000 years ago. The Red River then drained to the Mississippi River and left behind the Bayou Teche and Atchafalaya River channels. The modern-Teche (Figure 9) has three natural levees-a steep narrow inner relic levee of soil deposited by Red River, its own present day levee, and the gently sloping, wide levee of gray and brown alluvium deposited by the Mississippi River.

\subsection{Free State of Illinois in the Union}

Illinois became a free state in the Union in 1818. Nearby states and neighboring

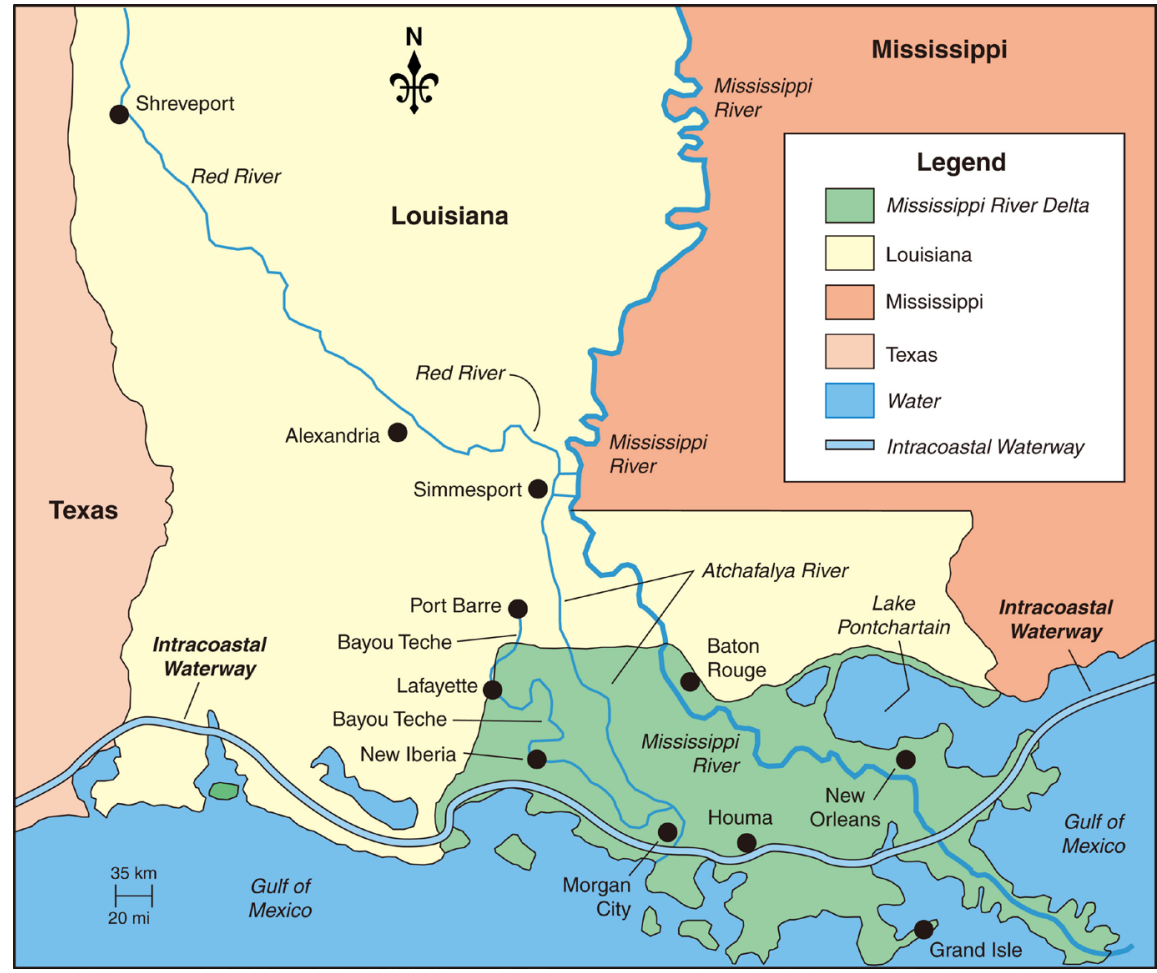

Figure 9. The map showing the Bayou Teche plus the Mississippi River Delta. Map by Mic Greenberg. 


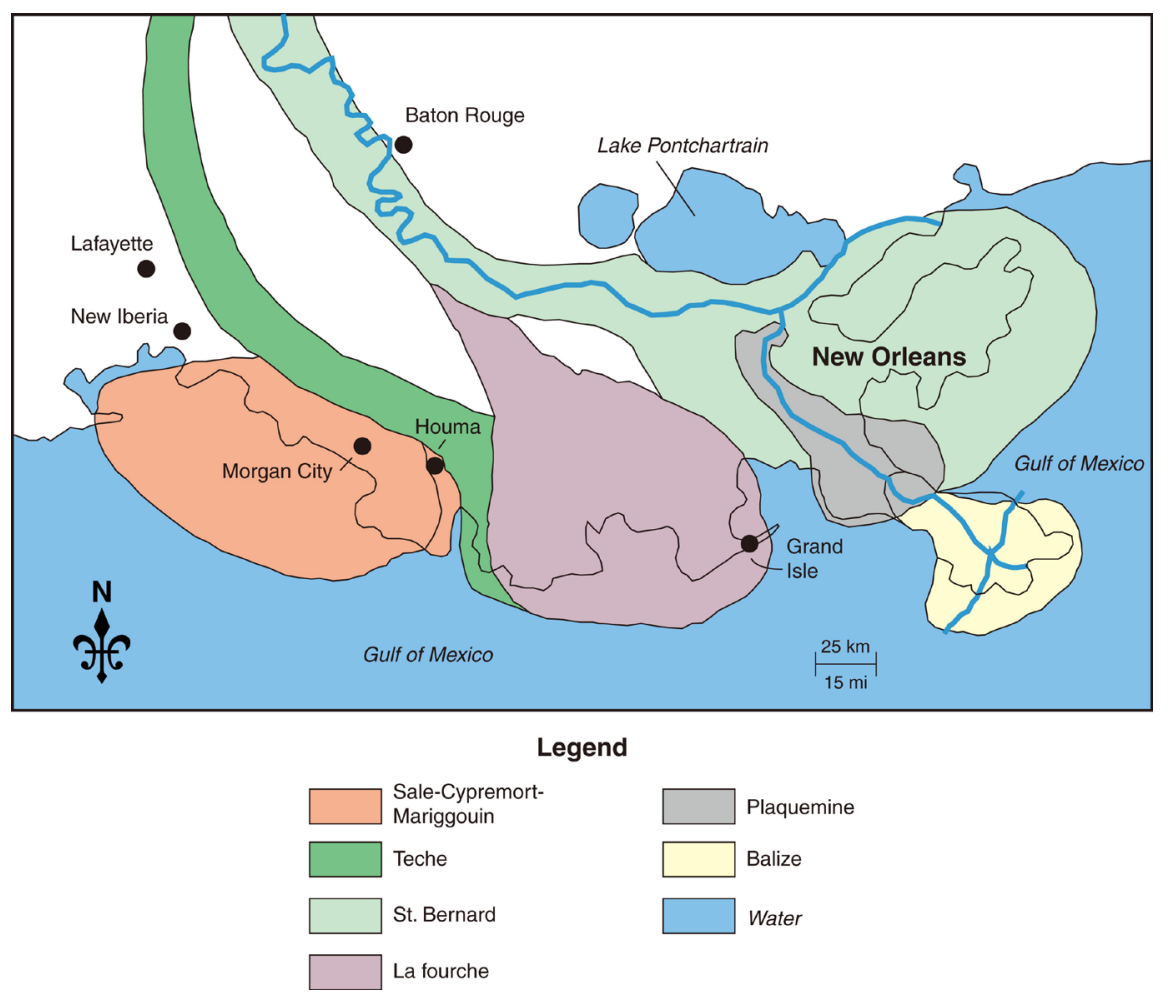

Figure 10. Mississippi River pathways during geologic time. Map by Mic Greenberg.

states, including Kentucky, Tennessee, Arkansas and Missouri were slave holding states. The two primary auction houses for slave sales were in St. Louis, Missouri and in Louisiana. Slaves seeking freedom often found their way across the Mississippi and Ohio rivers and then moved northeast along the Illinois River to Chicago. Another Underground Railroad pathway extended across the Ohio River and north along the Wabash River through Indiana [2]. In the 1850s prior to the American Civil War; Cairo Illinois had become an important transfer station on the Underground Railroad, fugitives were smuggled north on both the Ohio and Mississippi rivers and on the railroad lines headed toward Chicago or Galena, Illinois. About 150 years later, Cairo city workers discovered under the sidewalk along the 600 block of Levee Street storage bins (Figure 12) apparently used as an Underground Railroad hiding place for slaves [9] [18]. Physical evidence suggest that the rooms and adjoining tunnels (Figure 13) ran for five or six blocks along Canal Street and were utilized to transport and hide fugitive slaves.

\subsection{American Civil War}

The American Civil War started in 1861. At that time Cairo, Illinois had a population of 2200 with only 55 African-Americans. The Port of Cairo (Figure 14) became a strategically important training center and supply base for the Union army [19]. For a few months, Union Admiral Andrew Foote and General Ulysses S. Grant stayed at the grandest hotel in the Cairo area, the St. Charles Hotel 


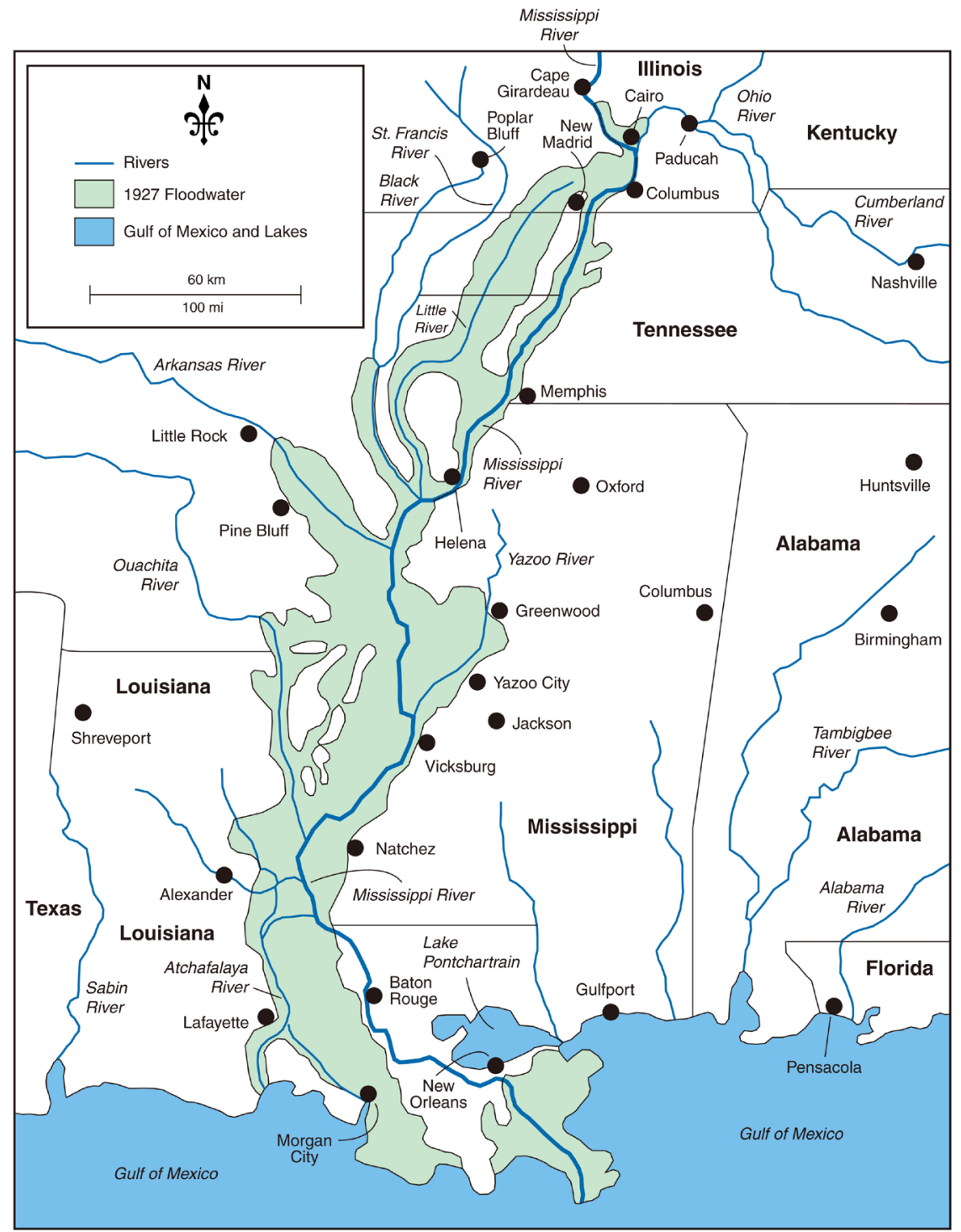

Figure 11. The 1927 flooding of the Lower Mississippi River Valley. Published with copyright permission from Book Editor of Soil and Water Conservation Society. Map by Mic Greenberg.

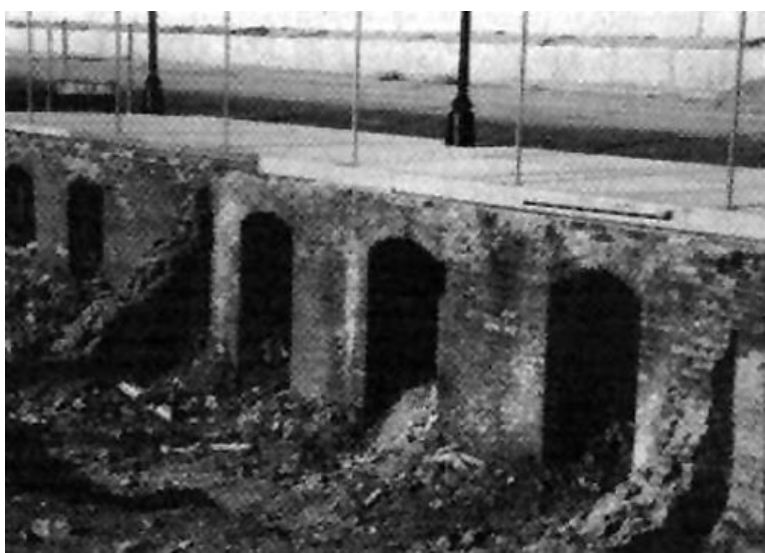

Figure 12. Underground railroad chambers and tunnels. 


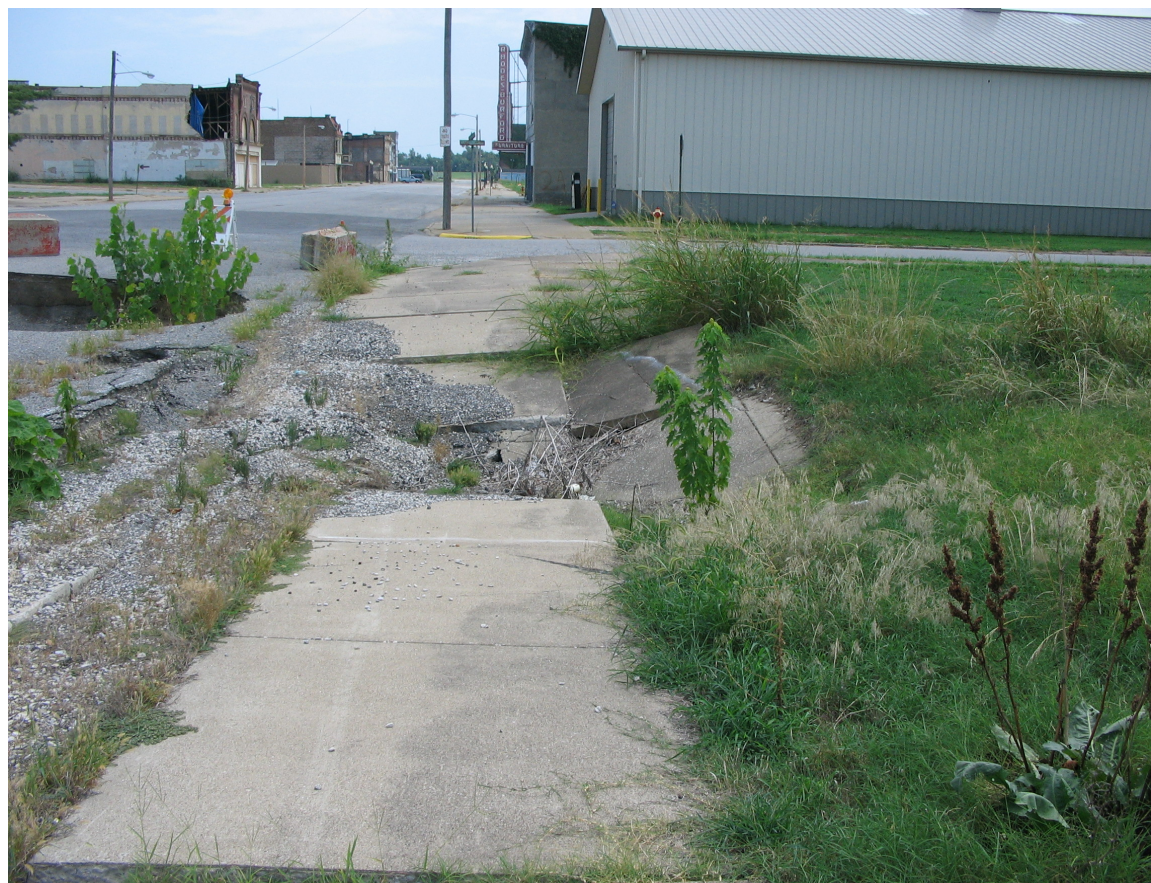

Figure 13. Canal Street which parallels the Ohio River near the underground chamber in Cairo.

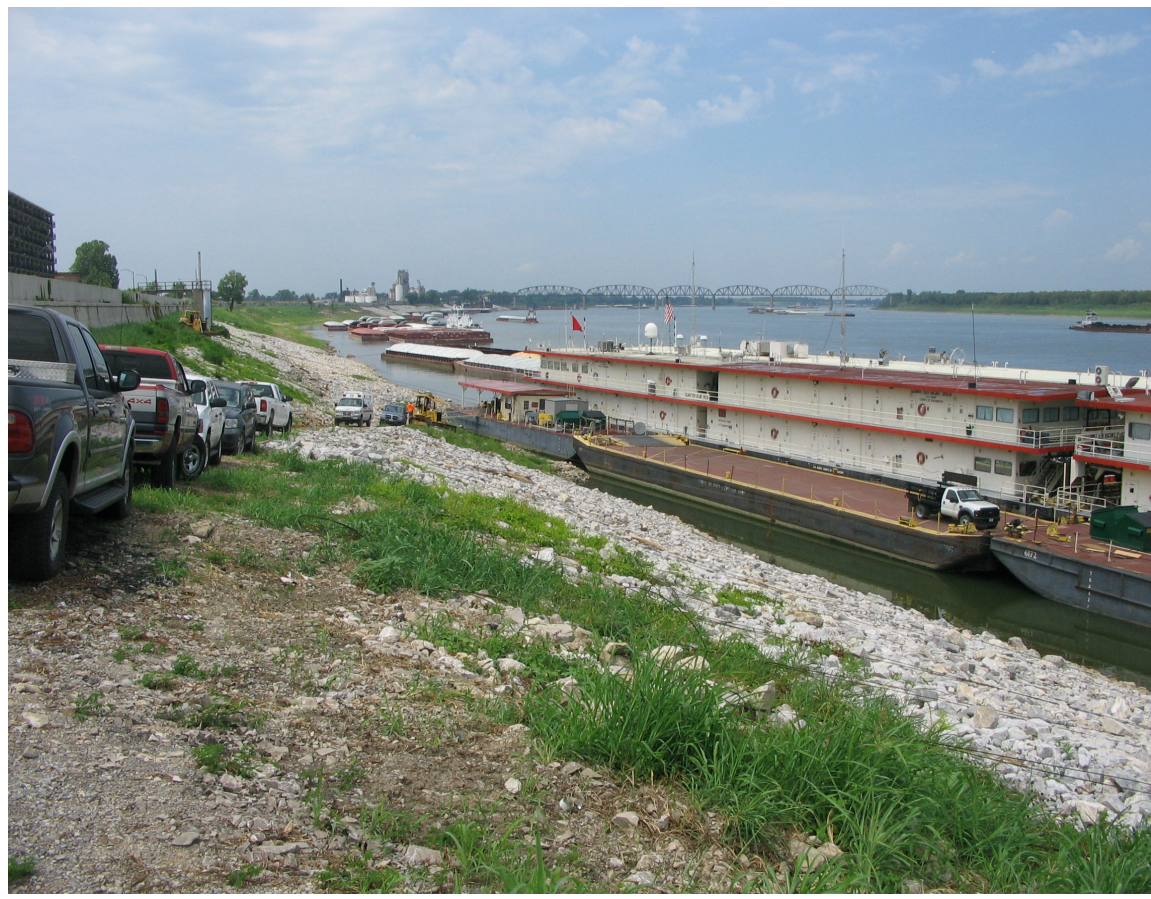

Figure 14. Cairo harbor during the dry year of 2012. The top of the floodwall can be seen above the vehicles. Published with copyright permission from Book Editor of Soil and Water Conservation Society.

(Figure 15), that opened in 1859 [20]. A number of new businesses were established including saloons, a hospital and a wheelwright shop. However, the saloons were closed down by the Union Generals in October of 1861. 


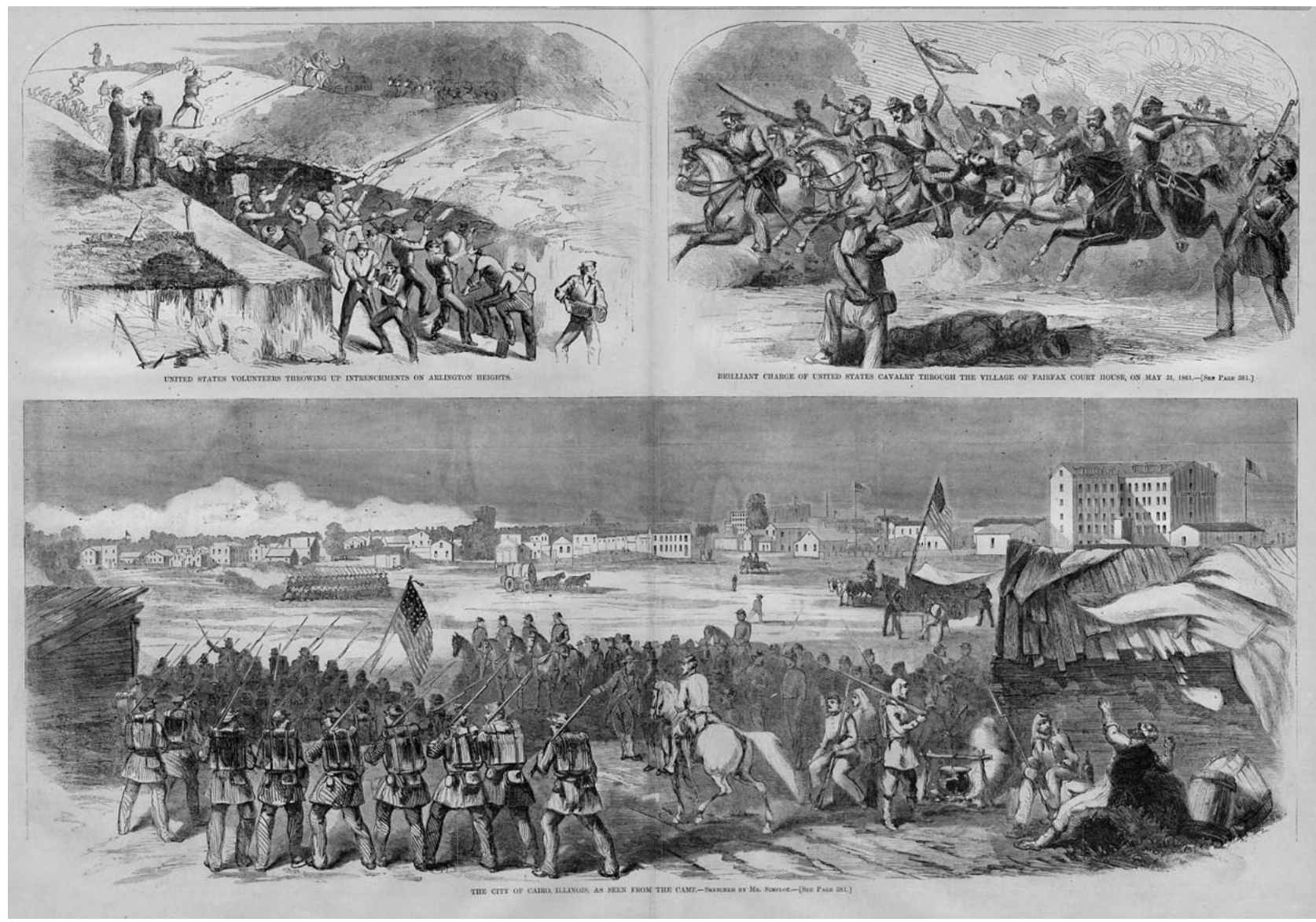

Figure 15. Union training camp located in the City of Cairo in 1860s. The bottom drawing shows the location of the five story hotel where General Grant stayed.

The Ohio River was contested during the Civil War. The presence of the Confederate troops along the Ohio River to engage the Union troops at the confluence of the Ohio and Mississippi rivers near Cairo, Illinois forced navigation and trade to be diverted to Lake Michigan and Chicago which was connected in 1848 with the Mississippi River and the Gulf of Mexico by way of the Illinois Waterway. The Illinois Waterway encompasses the Illinois River, the Des Plaines River, the Chicago Sanitary and Ship Canal, and the Chicago River [21].

Union gunboats (Figure 16 and Figure 17) built at Mound City, Illinois in the early 1860s, just north of Cairo, enabled Union troops to use the rivers to launch surprise attacks on forts located on the Ohio, Lower Mississippi, Cumberland and Tennessee rivers. These gunboats could transport thousands of Union soldiers which allowed Union troops to advance rapidly and to out-maneuver the Confederate Army and Navy [19].

Cairo became a huge military camp (Figure 15) with clusters of barracks on all sides and a large parade ground. The fortified city attracted many Union newspaper reporters who came, via the railroads, and riverboats on the Upper Mississippi River to observe and document the military build-up. Union troops stationed in Cairo did not like the location. The low, wet, flat bottomland alluvial 


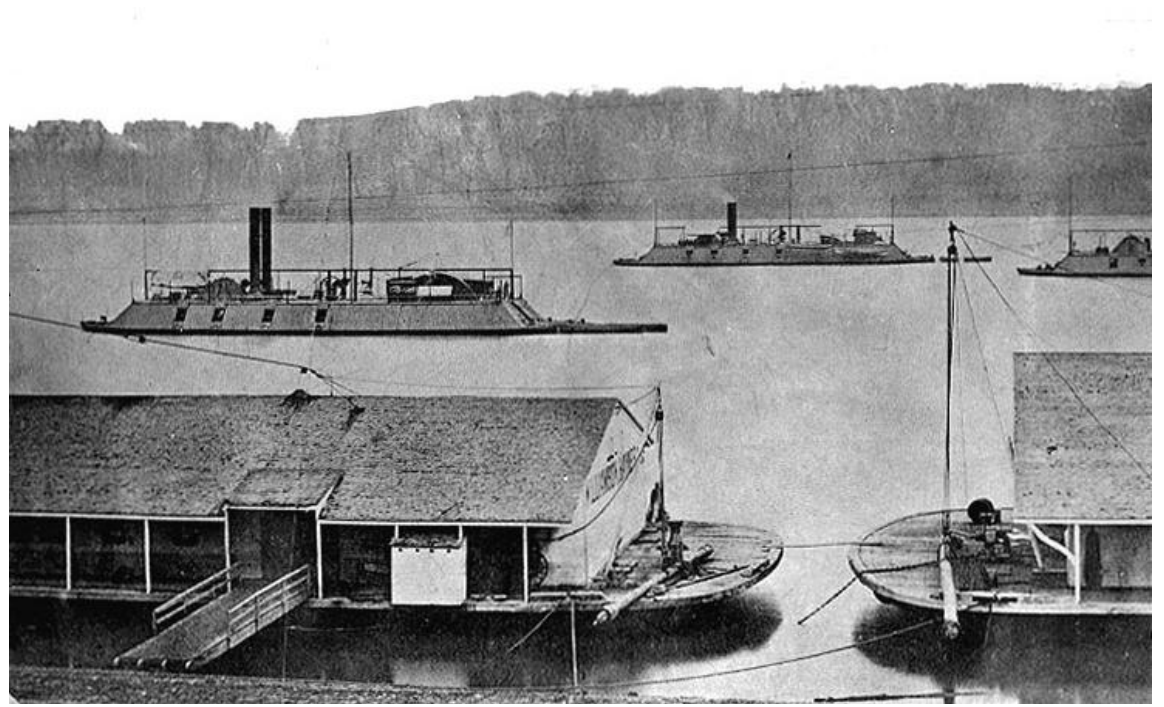

Figure 16. Gunboats near Mound City, Illinois.

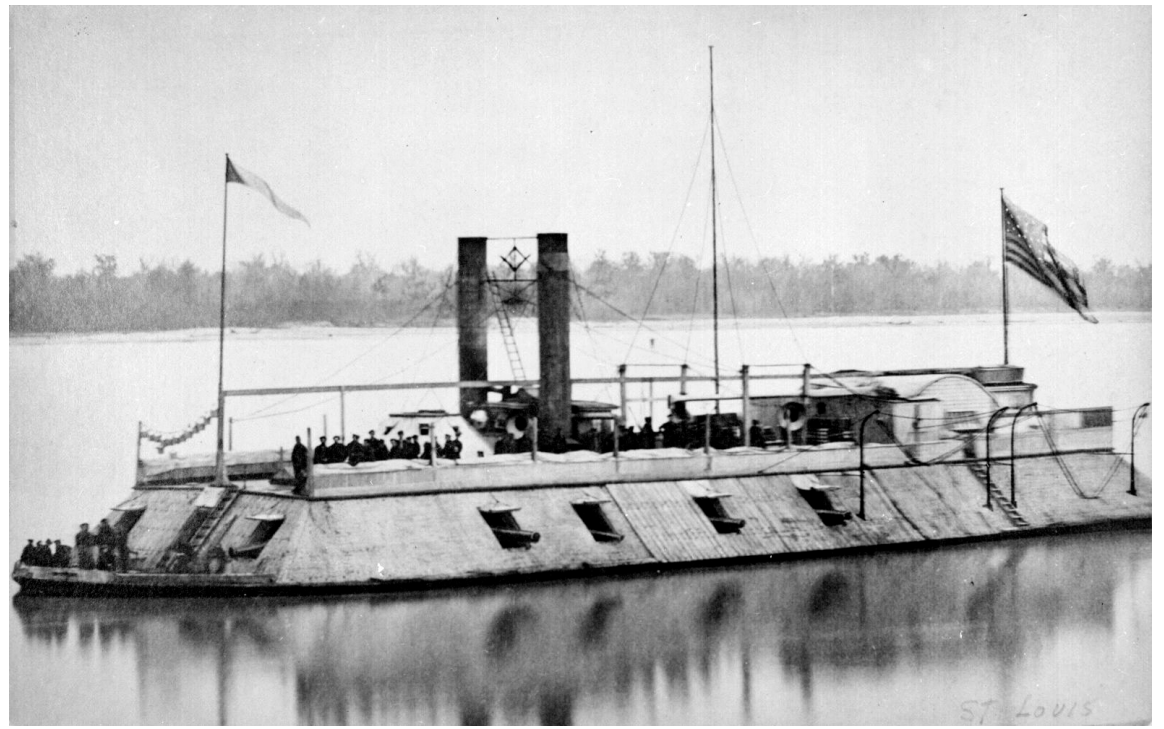

Figure 17. A steam powered gunboat named USS Baron DeKalb.

soils were extremely muddy, and prone to flooding despite some levees. The land was swampy, climate was humid, and disease-carrying mosquitoes and rats were everywhere [19].

\subsubsection{The Impact of Union Gunboats on the Mississippi, Ohio,} Cumberland and Tennessee River Waterways on the Outcome of the Civil War

The Union gunboats built at Mound City, Illinois (Figure 16 and Figure 17) impacted operations on the river. These gunboats could transport thousands of Union soldiers to advance rapidly on the Lower Mississippi, Cumberland, Ohio and Tennessee rivers and often out-maneuver the Confederate Army and Navy. However, the Union forces also sustained losses and many of the troops killed in action were buried at the national civil war cemetery in Mound City (Figure 18). 


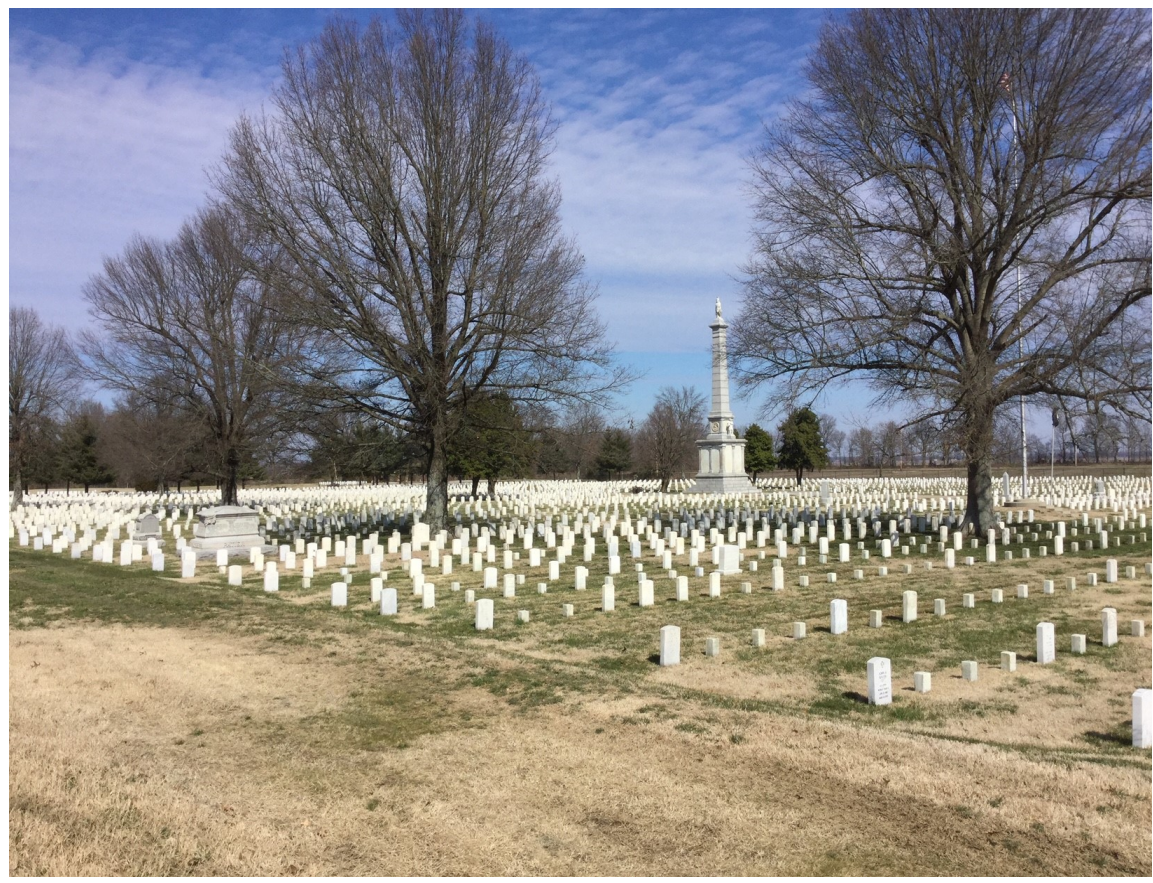

Figure 18. Civil war cemetery located in Mound City, Illinois near the site where the gunboats were built. Picture was taken by Pam Olson.

\subsubsection{Gibraltar of the West}

Troops on Sep. 3, 1861 under the command of Confederate General Leonidas Polk fortified a strategic line of bluffs near Columbus, Kentucky and on the east side of the Mississippi River. This was the first Confederate move into Kentucky. A huge chain was stretched across the Mississippi River to prevent passage of Union gunboats. The $1.6 \mathrm{~km}$ chain guarded by river mines stretched across the Mississippi River from Fort DeRussy near Columbus, Kentucky to Belmont, Missouri. Any Union gunboat that survived the river mines and long range rifled cannon on the Iron Banks bluff could be blocked by the chain barrier and finished off by the smoothbore, powerful and short range cannon on the river's bank.

On Nov. 6, 1861 Union General U.S. Grant moved the Union based troops from Cairo Illinois using steam powered gunboats (Figure 16) and transport boats to Columbus, Kentucky. Since confederate General Polk's Fort DeRussy defenses at Columbus (Figure 19) were very strong, General Grant decided to attack Camp Johnson, a Confederate outpost across the Mississippi River at Belmont, Missouri. General Grant, a tenacious officer looking to give his green troops experience pressed the Southern defenses attached to Camp Johnson at Belmont, Missouri. On Nov. 7, 1861, Union troops initially routed the Confederates, but after Southern re-enforcements crossed the Mississippi River from Columbus the federal troops returned to the Cairo base camp.

To the east of Fort DeRussy were Fort Donelson (Figure 20) on the Cumberland River and Fort Henry on the Tennessee River and their defenses were initially very strong. However, these Forts were stripped of defense resources to 


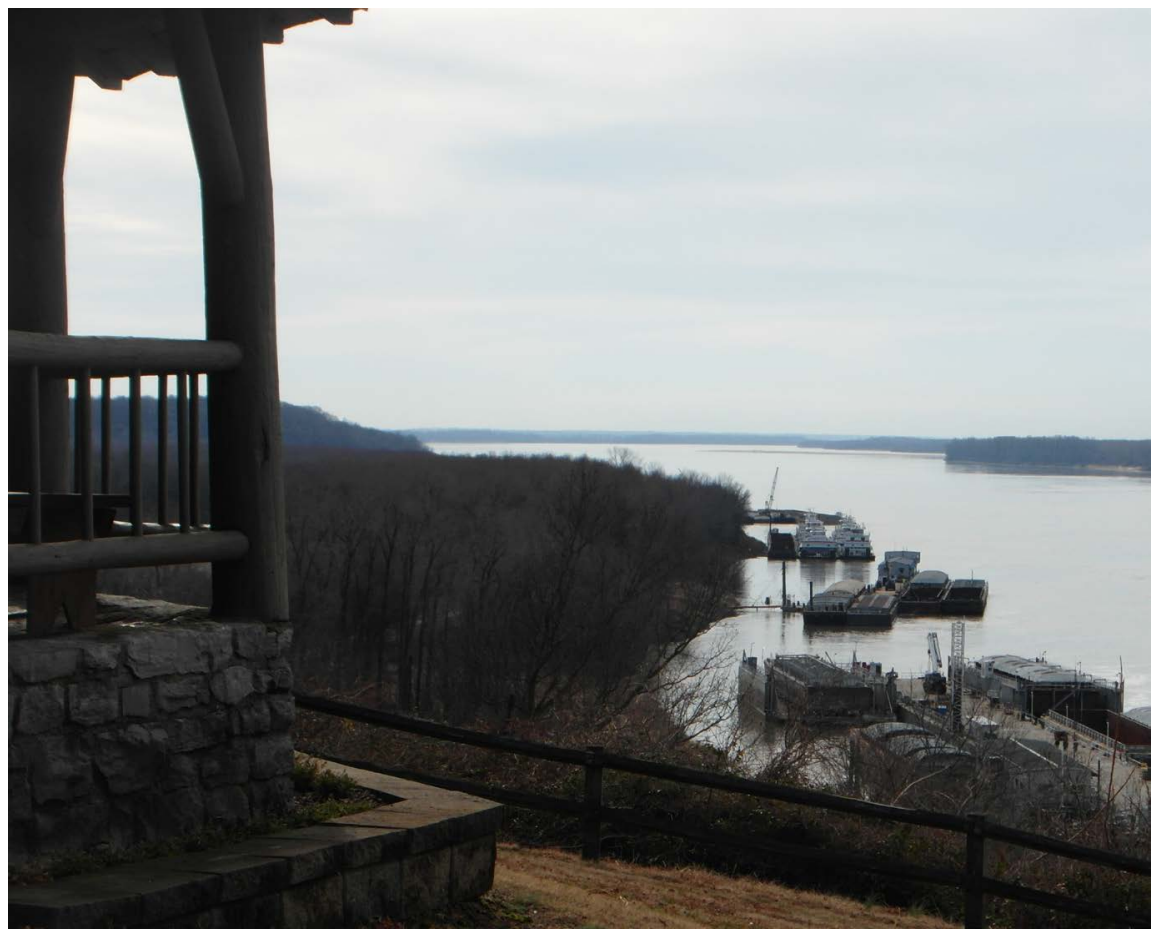

Figure 19. Modern day Columbus, Kentucky Harbor.

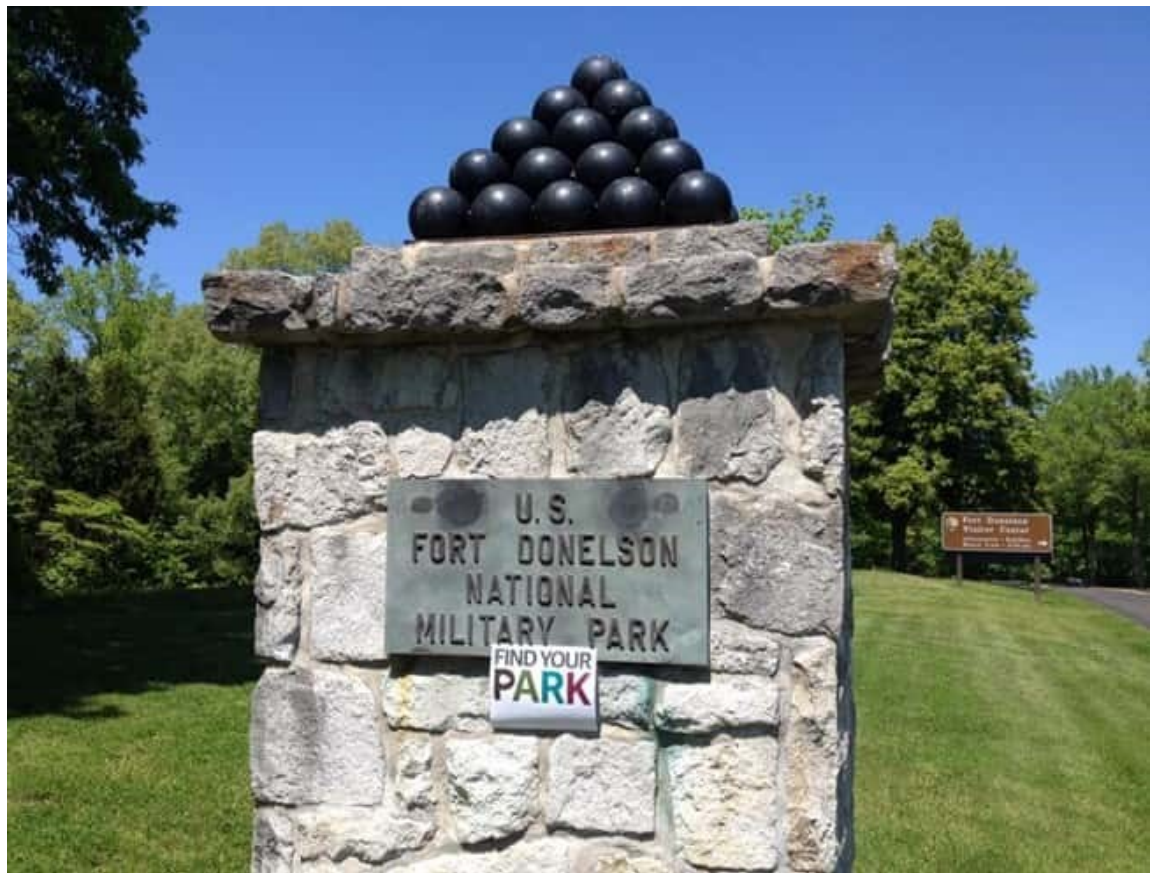

Figure 20. Fort Donelson sign with cannon ball.

support Columbus defense which resulted in Fort Donelson and Fort Henry river defense failures. Once the two forts, Fort Donelson and Fort Henry, to the east of Columbus fell the Kentucky positions could not be supported. After Union success in Tennessee (Fort Donelson and Fort Henry) the Confederate soldiers evacuated their Columbus "Gibraltar of the West" position on March 2, 
1862 (Figure 19). The Union troops on their gunboats moved in the next day and renamed the Confederate Fort DeRussy as Fort Halleck. The Union forces held the Columbus, Kentucky position, Fort Halleck, throughout the rest of the Civil War.

\subsubsection{Gunboat Battles for Fort Henry and Fort Donelson}

Fort Henry was situated on the Tennessee River bottomlands making it vulnerable to Union gunboat attacks. Fort Henry was key to General Albert Johnston's Confederate defense lines which guarded agricultural lands and mineral deposits. In early February 1862 Union General Henry Halleck sent General Ulysses S. Grant and Commodore Andrew Foote to capture Fort Henry and Fort Donelson. Seven gunboats and 15,000 men traveled up the Tennessee River to Fort Henry and captured the fort on February 6, 1862. Fort Henry, on bottomlands adjacent to the Tennessee River had been defended by only 2500 Confederate soldiers and General Lloyd Tilghman retreated $19 \mathrm{~km}$ overland to the east to Fort Donelson after fighting a short battle. The Confederate goal was to strengthen their defensive line. While the Union forces capture of Fort Henry came with minimal loss, 15 of life, only 42 wounded and 78 prisoners taken by the Union soldiers, the battle had huge strategic navigational consequences. The Union troops now controlled the northern most part of the Tennessee River with both waterway access and railroad access to Chattanooga, Tennessee. Fort Donelson (Figure 20 and Figure 21) then stood as the only remaining defense lynchpin protecting the Confederacy's western heartland and population centers.

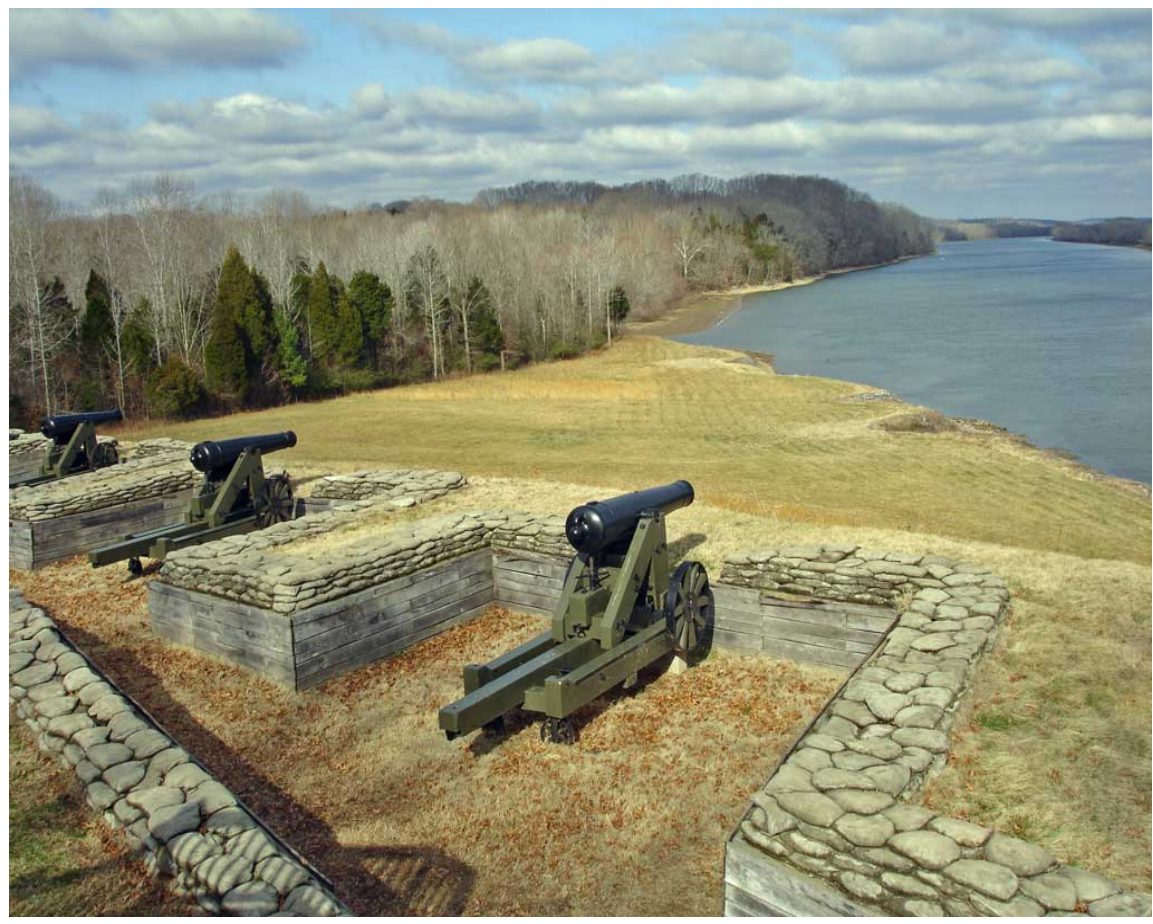

Figure 21. Fort Donelson river delivery battery. 
A week after the capture of Fort Henry by Union forces the Battle of Fort Donelson started (Figure 21). This battle took place from February 11-16, 1862. General Grant began the Union assault on Fort Donelson from the Cumberland River after the gunboats had time to move via the Tennessee River downriver to Paducah, then up the Ohio River to Smithland and then turned up the Cumberland River to Fort Donelson. On February 16, 1862, after General Floyd failed to break through Grant's lines, the confederation surrendered Fort Donelson. Under General Grant's “immediate and unconditional surrender” terms, these Union victories ensured that Kentucky would remain a northern state. These first two major Union victories in the Civil War restored most of Kentucky and middle Tennessee to the Union.

\subsubsection{Island No. 10 and Last Military Obstacles before Vicksburg}

Rucker's Battery was at the west end of a 1000 meter "creamillere" and was the Battery no. 1 in Confederate defenses of Island No. 10. The battery withstood two continuous weeks of attacks and prevented passage of Union vessels downriver. On April 2, 1862, the battery was abandoned as a result of Mississippi River flooding.

Moss Island or Cutoff Island on the Mississippi River was once a major landmark (Figure 4 and Figure 22). Moss Island was important because it was: 1) a reference point for navigation on the Mississippi River and 2) located at the headwaters of the Obion River. Col. Robert Dyer received a grant, in 1825, to build a canal between the Forked Deer and Obion rivers and to shorten by over $40 \mathrm{~km}$ the decent from the Mississippi River. In 1862 there was a lot of Civil War activity around Moss Island during the Civil War. Hale's Point which sits at the month of the Obion River was a major shipping transfer point for the pro-south. Moss Island and Hale's Point became focal points for Civil War naval activities.

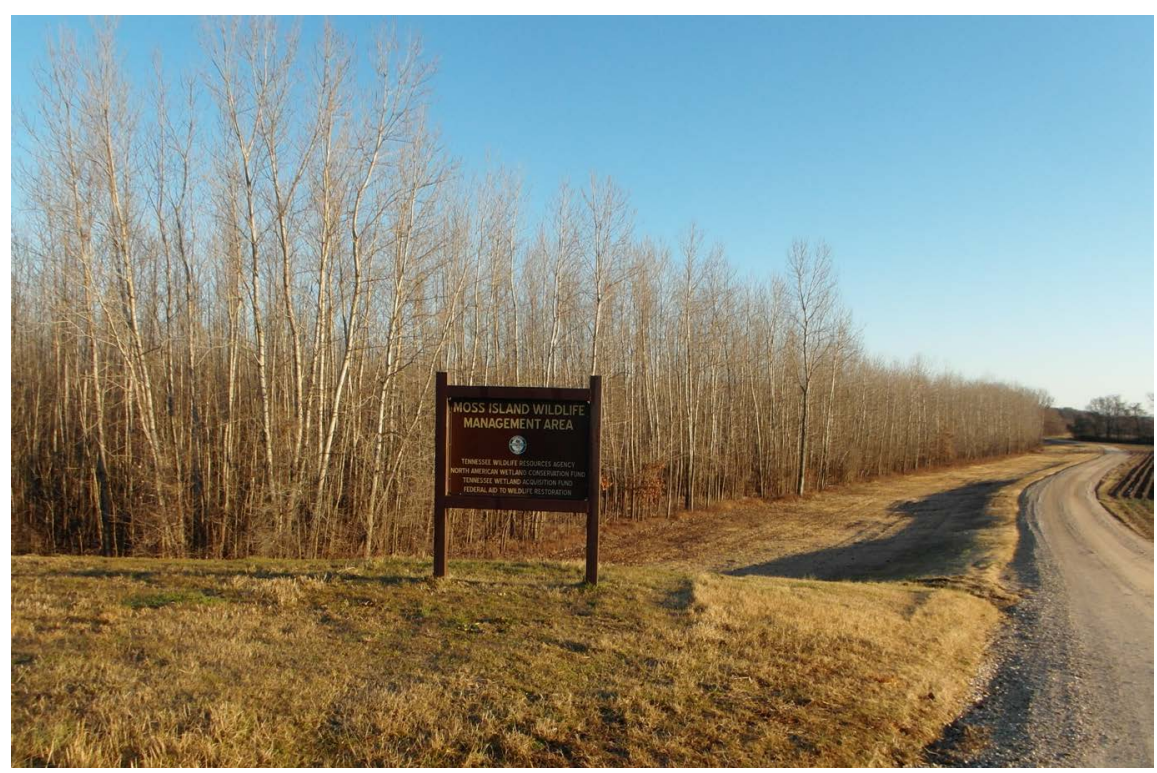

Figure 22. Moss Island sign. 


\subsubsection{Chattanooga Campaign-Tennessee River}

The "Battle of Lookout Mountain" was fought as part of the Chattanooga Campaign on November 24, 1863. There was no significant use of gunboats but navigational control of the Tennessee River was the goal. Union forces under General Joseph Hooker assaulted Lookout Mountain, Chattanooga, Tennessee and defeated Confederate forces commanded by General Carter Stevenson. Lookout Mountain was another engagement of Chattanooga battles between Confederate General Braxton of Confederate Army of Tennessee and General Ulysses Grant's Military Division of the Mississippi. The Battle of Lookout Mountain Union forces drove the left flank which allowed Hooker's forces to assist in the Battle of Missionary Ridge on November 25, 1863. Union Troops did scale Lookout Mountain and occupy the peak. However, historians now consider the "Battle of Lookout Mountain" to be one of the "romances of the Civil War". Some historians suggest that no action took place worthy of being called the "Battle of Lookout Mountain". However, the Chattanooga Campaign action was very important in assuring the Union control of railroad into Chattanooga which borders the Tennessee River and eventually provided two (railroad and river) supply lines for future Union penetration into the Deep South. Bragg's Confederate army was routed, freeing Union forces in Chattanooga and opened the gateway into the Deep South for General Sherman's eventual "March to the Sea" via the Tennessee River and tributaries and then overland to Georgia.

\subsubsection{Vicksburg Campaign}

Prior to the Vicksburg Campaign, four Federal gunboats with twenty-seven guns traveled up the Teche in November 3-5, 1862 and engaged a modified Confederate gunboat which was originally a steam boat (Figure 9). These four Union gunboats later re-engaged the Confederate gunboats on January 14, 1863 and later in 1864 and 1865.

The Vicksburg Campaign was directed by Major General Ulysses S. Grant against Vicksburg, Mississippi, a fortress city controlled by the Confederate forces. Vicksburg, Mississippi was the last Confederate controlled section of the Mississippi River. The Union army under Major General Grant gained navigational control of the Mississippi River by eventually capturing Vicksburg on July 4, 1863.

The Campaign consisted of many important naval battles on the Mississippi River (Figure 23) from December 26, 1862 to July 4, 1863. Initially General Grant tried to capture Vicksburg by sending half his Army to advance down the Yazoo River which is east of the Mississippi Delta and attack Vicksburg from the northeast and the other half of his Army would advance down the Mississippi Central Railroad. Both initiatives failed. General Grant then tried using waterborne access to the State of Mississippi south of Vicksburg's artillery batteries. All five attempts failed. Finally, Union gunboats and troops transported by boats ran the batteries at Vicksburg (Figure 23) and meet up with Grant's men who had marched overland from Louisiana. On April 29 and 30, 1863 General Grant's army crossed the Mississippi River and landed at Bruinsburg, Mississippi. 


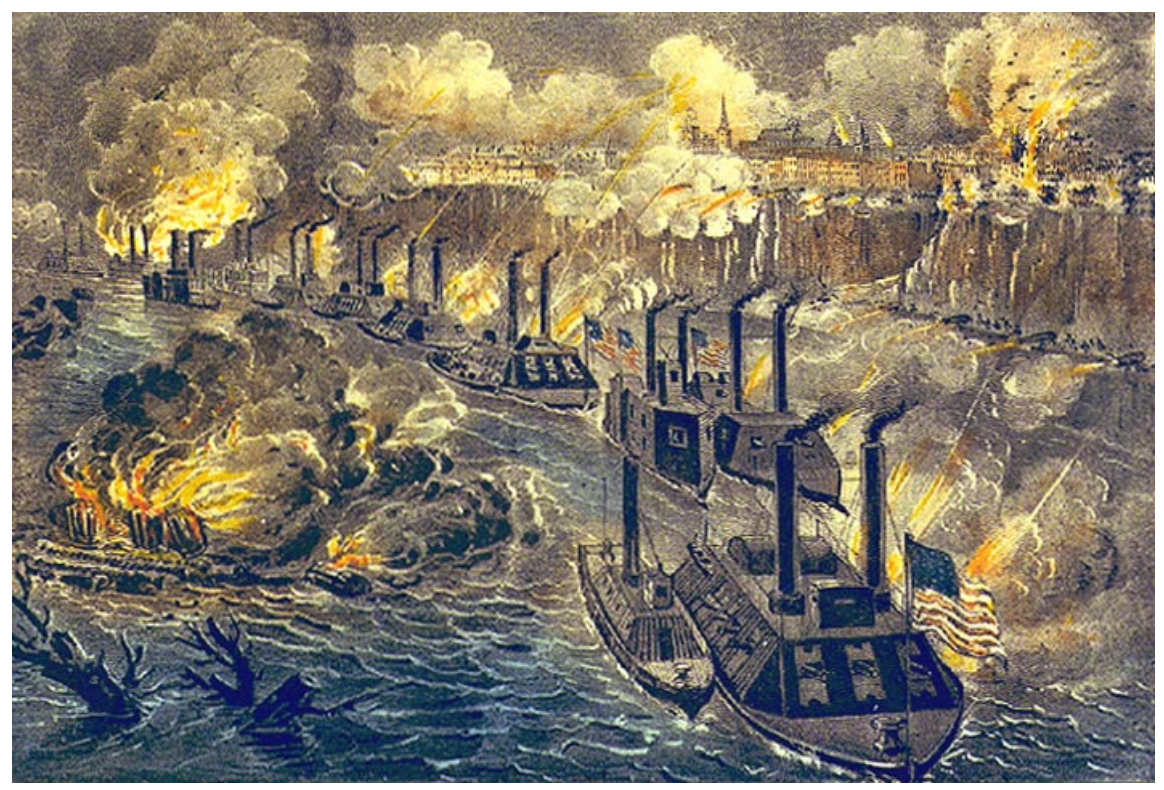

Figure 23. Vicksburg battle with gunboats firing on the city.

Over the next 17 days, General Grant's army maneuvered inland and won 5 battles, captured the state capital of Jackson, Mississippi and sieged Vicksburg. The Confederate Army surrendered on July 4, 1863 and after Port Hudson surrendered on July 9, 1863 the states of Arkansas and Texas were effectively cut off from the Confederacy. The Mississippi River was once again open for northern commerce to reach the Gulf of Mexico. Almost 3000 Union and Confederate soldiers were killed, and approximately 10,000 soldiers were wounded during the Vicksburg campaign; a rather high price to pay to gain navigational control of the Lower Mississippi River and restore a trade route.

\section{Flood Control and the 1927 Flood}

In April of 1926, the USACE completed the construction of an extensive levee system along the Lower Mississippi River stretching from Cairo, Illinois to New Orleans; and publicly declared that the levees would prevent future flood damage. This confident claim was short-lived. On, January 1, 1927 the first of multiple crests reached flood stage on the Mississippi River with the Cairo gage cresting at $16.6 \mathrm{~m}$ [4]. The Mississippi River Commission insisted the levees would hold. However, a crevasse at Dorena (Missouri), just north of New Madrid, flooded Missouri agricultural lands reducing the readings at Cairo and Hickman gages by $0.6 \mathrm{~m}$ in less than 24 hours [22].

The great flood of 1927 resulted in overflows in the Cairo and Cache River area but the flood damage was considered to begin just $48 \mathrm{~km}$ south of Cairo, Illinois at Dorena, Missouri, when a $3600 \mathrm{~m}$ length of the federal government levee collapsed and flooded 70,000 ha and the entire town of New Madrid, Missouri [23]. In some places the Mississippi River was carrying 84,950 cu m/s-an unprecedented volume [4]. 
Communities on both sides of the river knew that if the levee breaks on one side, the other side will be spared. Each side of the river feared sabotage, and set up levee patrols to prevent intruders from dynamiting their levee. The patrols were prepared to shoot to kill. Approximately 7,355,566 ha of lower Mississippi River bottomlands [22] [23] and home to more than 931,000 people were inundated. Millions of hectares across seven states were flooded (Figure 11). Evacuees totaled 500,000 and economic losses were estimated at US\$1 billion in 1927 dollars which was equivalent to one-third of the federal budget. Post-1927, it was clear the Mississippi River levee system as designed was inadequate to protect against record high river levels.

\subsection{Attempts to Reduce Ohio and Mississippi River Peak Flows after Flood of 1927}

After the 1927 Mississippi River flood disaster, General Edgar Jadwin instructed the Mississippi River Commission (MRC) to develop an alternative to the levees-only policy [4] [22]. To protect Cairo and the levee system along the Lower Mississippi River, the MRC studied a number of alternatives including elevating the Cairo above the floodplain and the construction of diversion channels and floodways to add storage when the river exceeded flood stage. Elevating the town of Cairo to the proposed height would have taken 43.6 million $\mathrm{cu} \mathrm{m}$ of soil materials. The elevated the City would require replacing the sewer system, $37 \mathrm{~km}$ of streets, $700 \mathrm{~km}$ of sidewalks, and nearly 4000 homes and businesses at a cost of $\$ 30$ million (1927 dollars). Diversions in Missouri, such as through St. Francis basin to White River basin [4], were projected to cost at least US\$220 million (1927 dollars). Instead, the MRC proposed levee setbacks at constricted points and raised the level of protection at Cairo to $21.3 \mathrm{~m}$ on Cairo gage. This plan was accepted by the U.S. Congress and authorized in the 1928 Flood Control Act.

The MRC/USACE employed a variety of engineering techniques in Jadwin's "make room for the river" plan, to control the Lower Mississippi River floods. The primary approach prior to 1927 was to build levees on all bottomland areas adjacent to the Lower Mississippi River. The "make room for the river" plan expanded the arsenal of technics after the Flood of 1927 and included creation of four floodways (Figure 24) to safely divert excess flows past critical reaches, channel improvement to increase carrying capacity of the rivers and backwater areas to store surface floodwaters and reduce pressure on the levee system. Channel training structures were used to protect the integrity of the levee system to ensure proper alignment and depth of navigation channel, headwater reservoirs, tributary basin improvements including levees, and pumping stations to maximize the benefits realized along the main channel by expanding flood protection coverage and improving drainage into adjacent areas within the Lower Mississippi River alluvial valley [22].

In the last two centuries the Mississippi River and tributaries were the navigational highways of trade, adventure, and settlement have become agricultural 
economic engines as humans re-engineered the Lower Mississippi River and their bottomlands. Created backwater areas, channelized rivers, levees and floodwalls, floodways, aqueducts and an extensive system of reservoirs have been constructed to manage the Lower Mississippi River and its tributaries for navigation and to protect communities, agriculture and other high value land uses. In addition to attempts to control the courses and height of the Lower Mississippi River and tributaries, diversion ditches and systematic draining of interior wetlands and swamps have transformed hydric but fertile soils into intensely managed, highly productive agricultural lands. Paradoxically these infrastructure investments intended to reduce direct risks of flooding and facilitate navigation have led to unexpected consequences to the larger ecosystem.

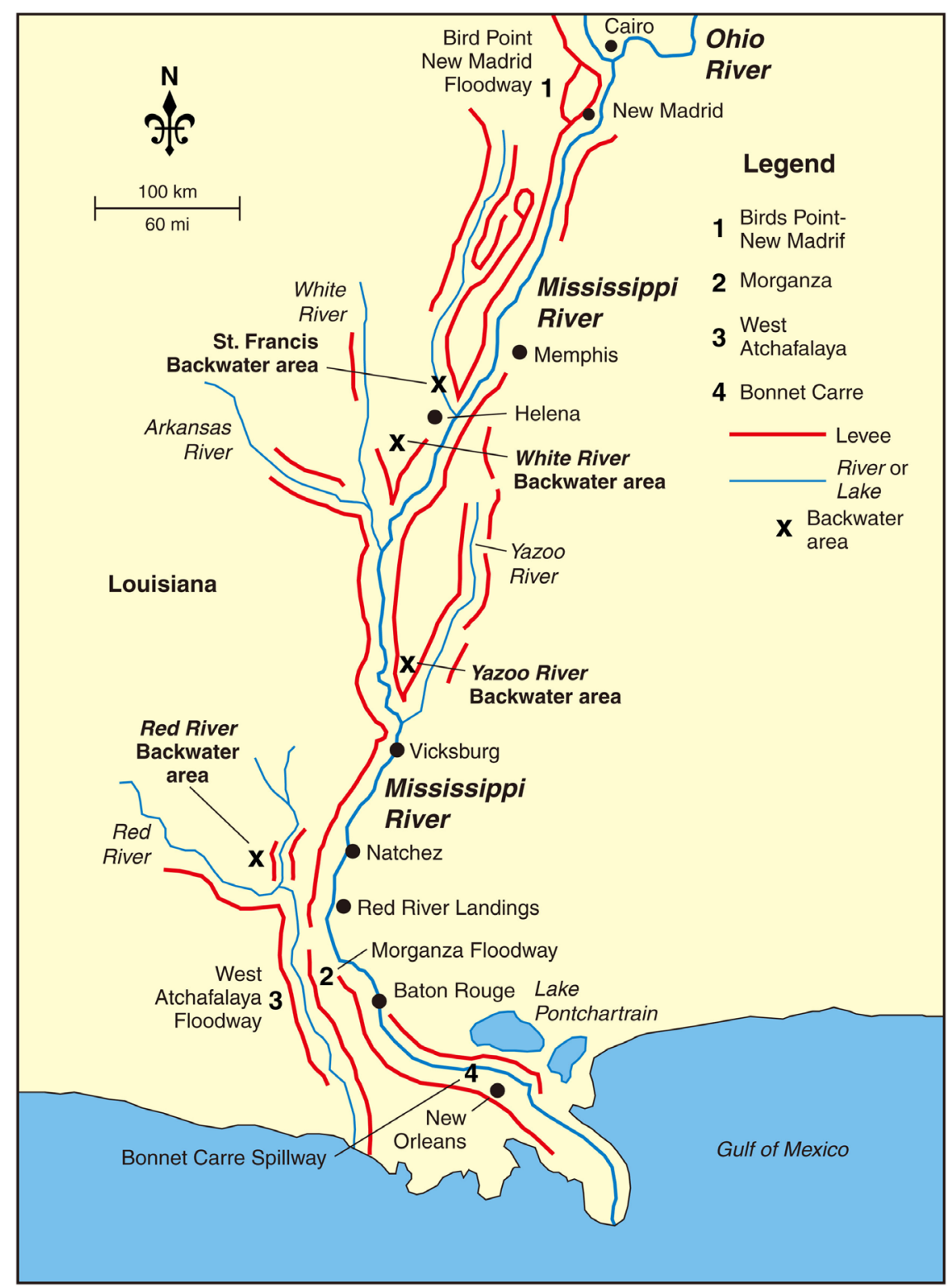

Figure 24. The four floodways plus the storage areas on the Lower Mississippi River. Map by Mic Greenberg. 
Recent levee breaching has created new knowledge about hydrology, soils, and the vegetation of rivers and their bottomland as a result of unexpected shocks to the river ecosystem. Despite the presence of well-engineered structures their occasional failure reminds us that the river landscape is a complex human-natural system. This complex system is ever changing, dynamic and often managed based on assumptions of steady state expectations where the past predicted the future. These assumptions do not prepare communities well to deal with often competing diverse societal goals under an increasing populations, increasingly variable climate, and intensified land uses [23] [24].

The Great Flood of 2011 [25] [26] and drought of 2012 [10] well illustrate some of the unintended consequences and vulnerabilities that arise from designing and managing river systems without taking into account their changing nature and the need for more flexible-adaptive capacities [23] [24] [27] [28]. Following the Great Flood of 1927 [20], it became apparent that the extensive use of levees (Figure 24), confinement and channelization of the rivers was inadequate to effectively contain the Mississippi River and tributaries [22]. The subsequent addition of reservoirs, including the Barkley and Kentucky, upstream of the confluence of the Ohio and Mississippi rivers and four downstream floodways (Figure 24) below were a substantive shift by the USACE to strategically incorporate confinement engineering with a dispersion risk management strategy [21] [22]. The underlying premise of dispersion is to duplicate the natural floodplain functions of bottomlands which historically served as outlets to rivers under flood conditions.

The 2011 the Birds Point-New Madrid floodway induced levee breaching reaffirmed the effectiveness of dispersion management and its capacity to protect the integrity of communities and land uses along the larger river system. However, 74 years had lapsed since 1937, the first time the floodway was used. The new damage to 200 buildings including 75 homes (Figure 25), the loss of 12,000 ha

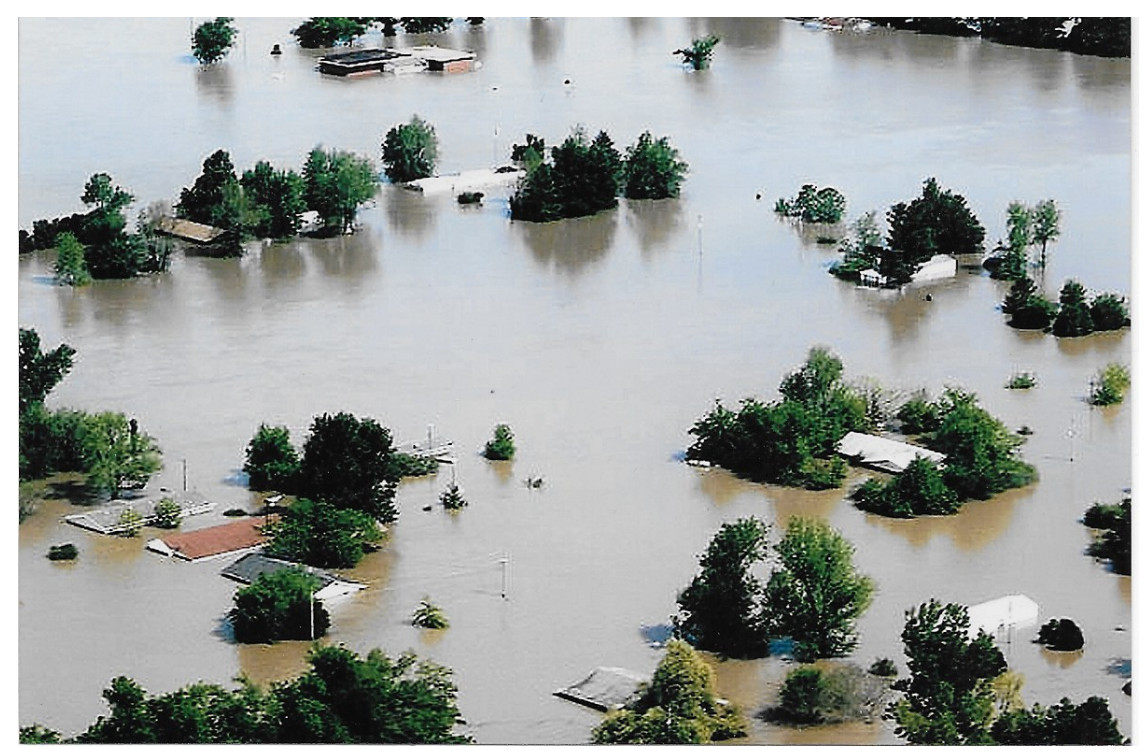

Figure 25. Flooding at Pinhook. Picture obtained from Deb Roberson Taver. 
of spring wheat and damage to over 400 cropland fields, the landowners and residents were unprepared for the consequences of opening the floodway. Reemergence of competing social values and social tensions has risen to reassess the uses of river bottomlands by public policy makers, environmental advocates, community leaders, and government agencies. They are challenged to defend the impacts and benefits of leveed structures that in recent history have protected rural agricultural and urban land uses. Although most river flooding has repetitive patterns reoccurring seasonally and over a period of years presenting known risks, floods are complicated in their range of duration and intensity and can result in unexpected consequences [29]. Structural failures including levee breaching (Figure 26) are often the result of unusually high peak runoff in a system cut off from its historical floodplain. Science is just beginning to understand the relationship between the river and its floodplain, the roles of wetlands and riparian corridors and the beneficial aspects of flooding and as well as the extensive economic and social damaging floods wreak on the livelihoods of people working and living along the river.

There is evidence that a new type of river management is required, one that goes beyond the current confinement-dispersion strategy. Park et al. [24] call for resilience management, an adaptive management approach to changing conditions that preserves the natural functions of the river ecosystem in ways that minimize catastrophic failure of engineered structures. This concept is just emerging with many practical details remaining to be addressed. Some of these details involve the soil resource immediately after levee breaches and subsequent flood events [30] and better inventories and assessments. Updated land scouring and deposition surveys and soil surveys (Figures 27-29) can be used to guide restoration decisions when engaging and informing the public so as to come to politically acceptable agreement on management and land use decisions and create a better understanding of the ecosystem services the floodplain provides.

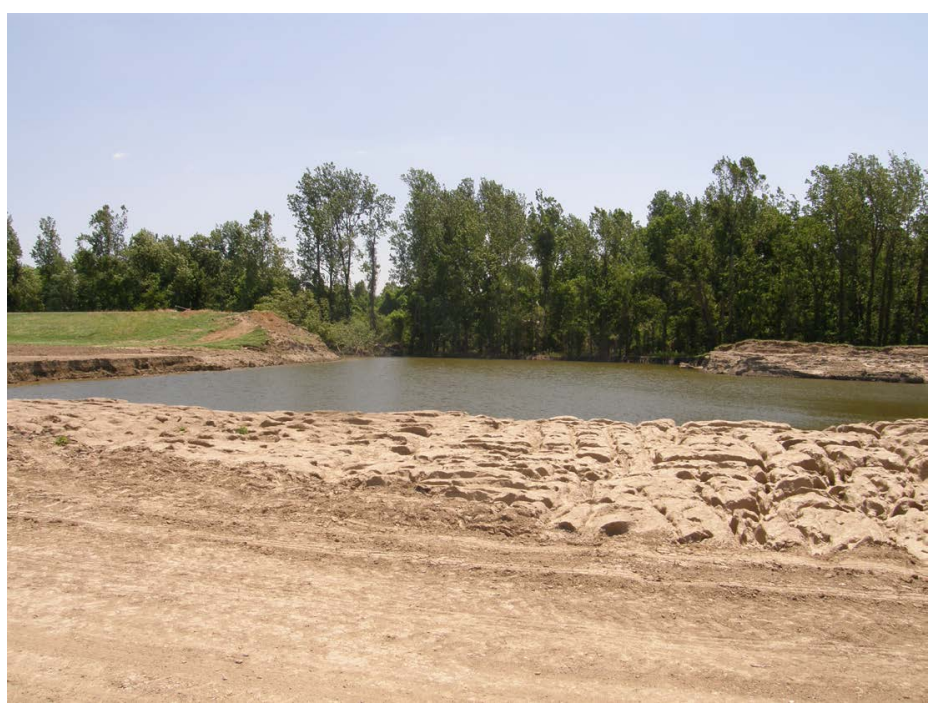

Figure 26. Breached New Madrid floodway levee at Birds Point. Photograph taken by Lois Wright Morton. 


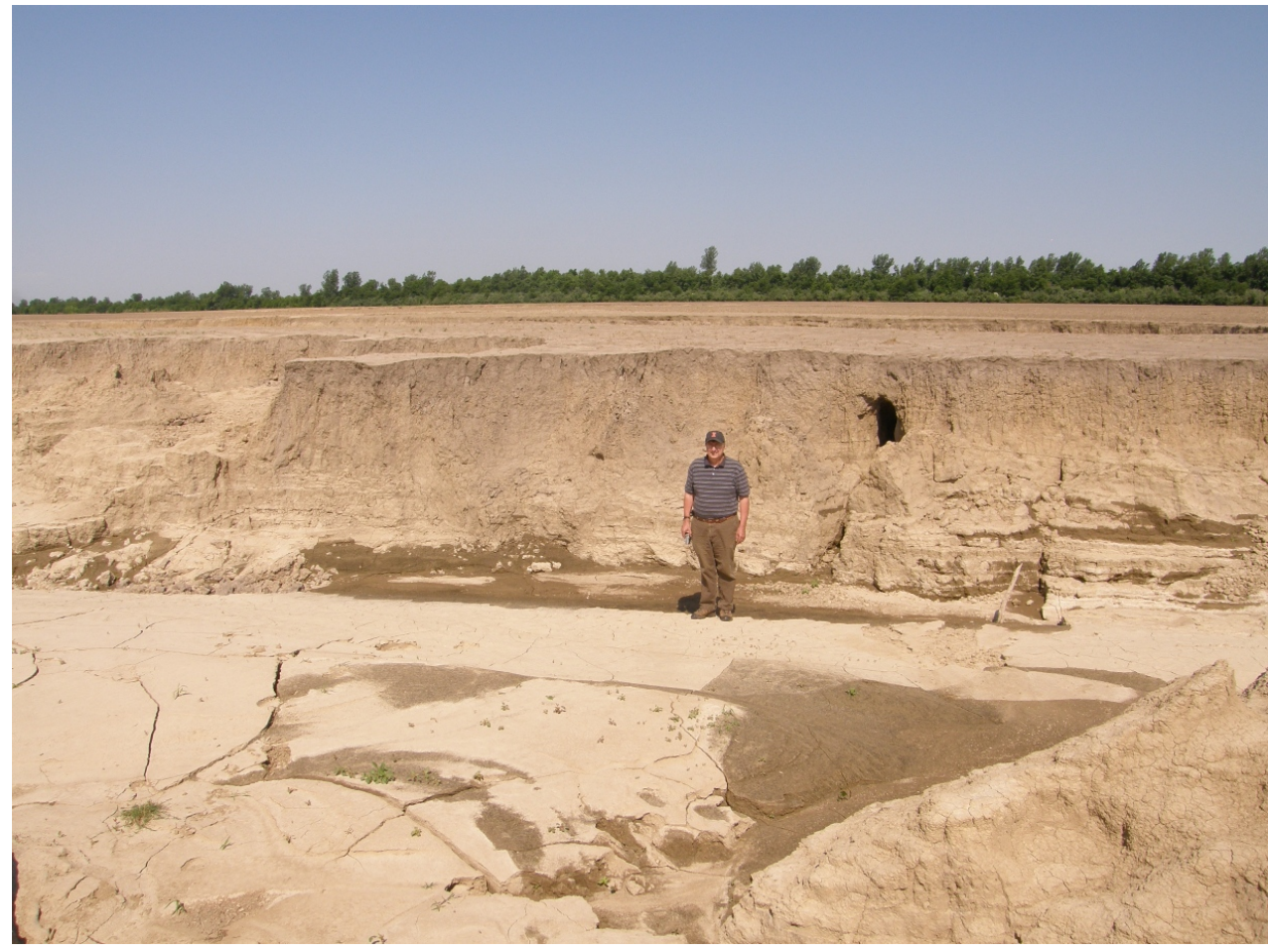

Figure 27. O’Bryan ridge $2 \mathrm{~m}$ deep gullies. Photograph taken by Lois Wright Morton.

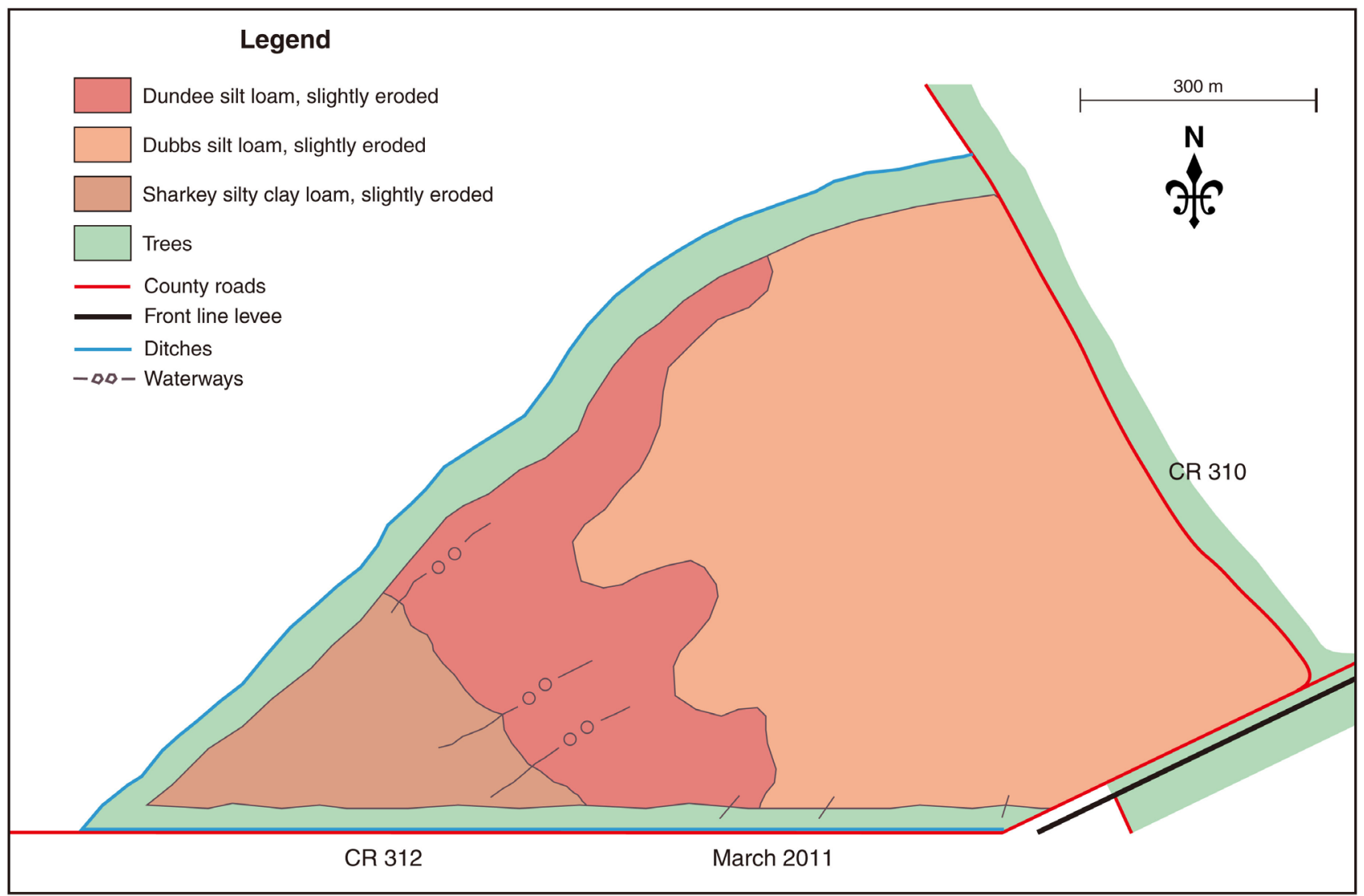

Figure 28. Soil map before flood of 2011. Published with copyright permission from Book Editor of Soil and Water Conservation Society. Map by Mic Greenburg. 


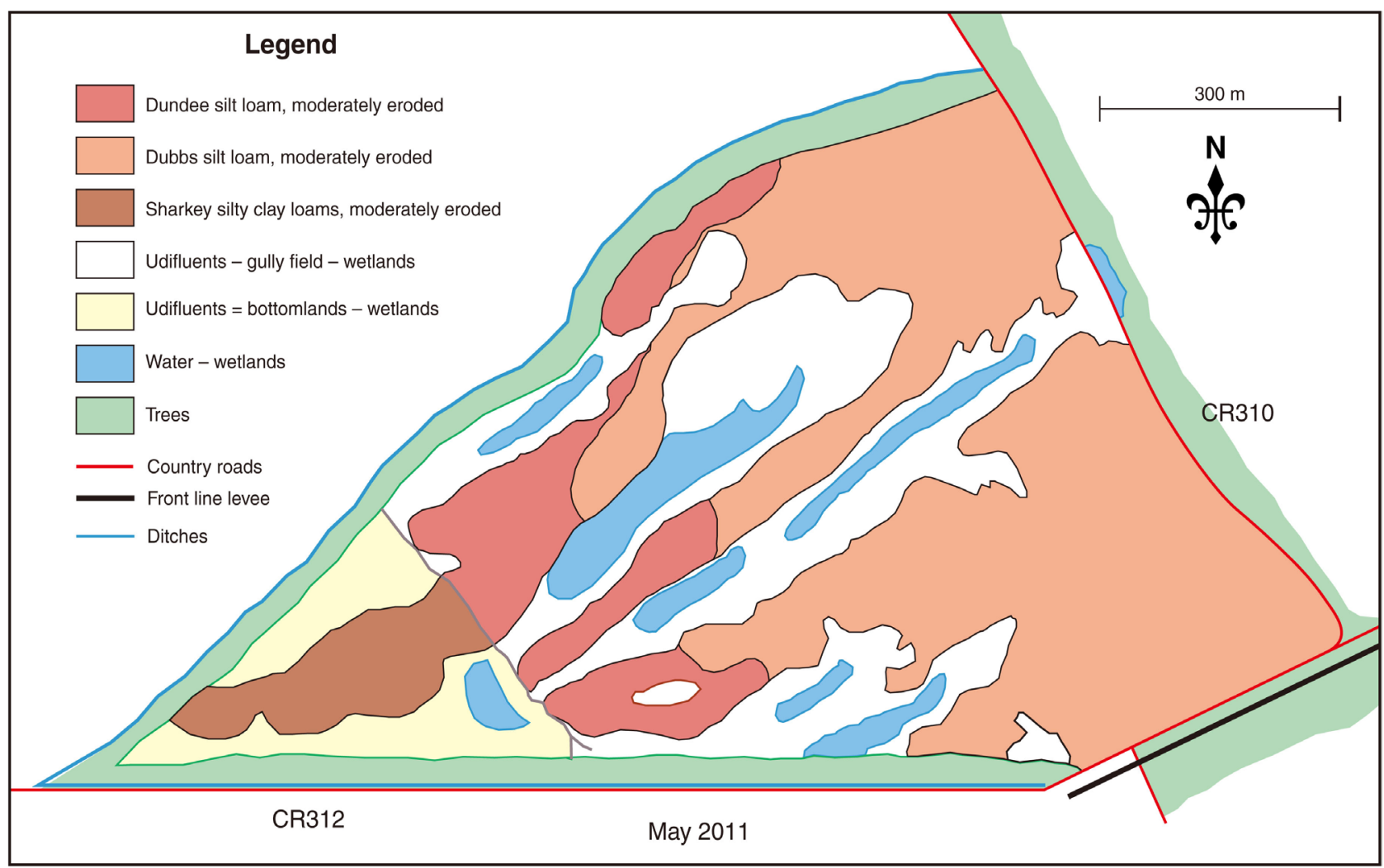

Figure 29. Soil map after flood of 2011. Published with copyright permission from Book Editor of Soil and Water Conservation Society. Map by Mic Greenburg.

The current levee system integrity can be bolstered by advancements in the design, installation, construction, and maintenance of seepage control measures, to include landside drainage trenches, drainage banks, berms, and relief wells (Figure 30) [22] [30]. More than $1600 \mathrm{~km}$ of concrete mattress revetment assures reliability of the navigational channel and protects the levee system from erosion. Local partners implemented strict annual levee maintenance program with their own funds and labor. Activities include clearing brush and trees, filing holes, mowing, restoring rain-washed or eroded areas, clearing and cleaning drainage ditches (Figure 31), correcting weed control and drainage problems.

\subsection{New Madrid Floodway}

The key location of the flood control system on Lower Mississippi River is the Birds Point-New Madrid floodway [1] [26] [28]. The Floodway has a front line levee adjacent to Lower Mississippi River and setback levee 6 to $16 \mathrm{~km}$ west of the frontline levee. The Mississippi River floodway diverted up to one-quarter of the Lower Mississippi River or 15,574 cu m/s during the flood of 2011.

Between Old River control complex and Birds Point-New Madrid Floodway (Figure 32), flood management relies on levees. A combination of flood control reservoirs in White-Arkansas basin and a comprehensive channel rectification program supplemented the levee system in lowering the project flood flow line 


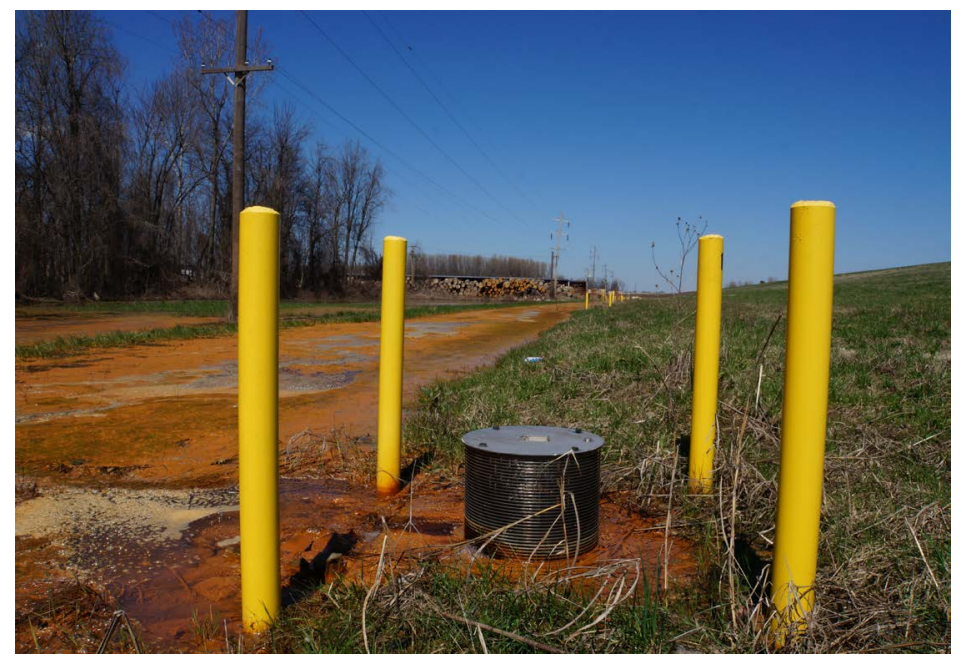

Figure 30. Relief well along the Ohio River and Levee Street. Published with copyright permission from Book Editor of Soil and Water Conservation Society.

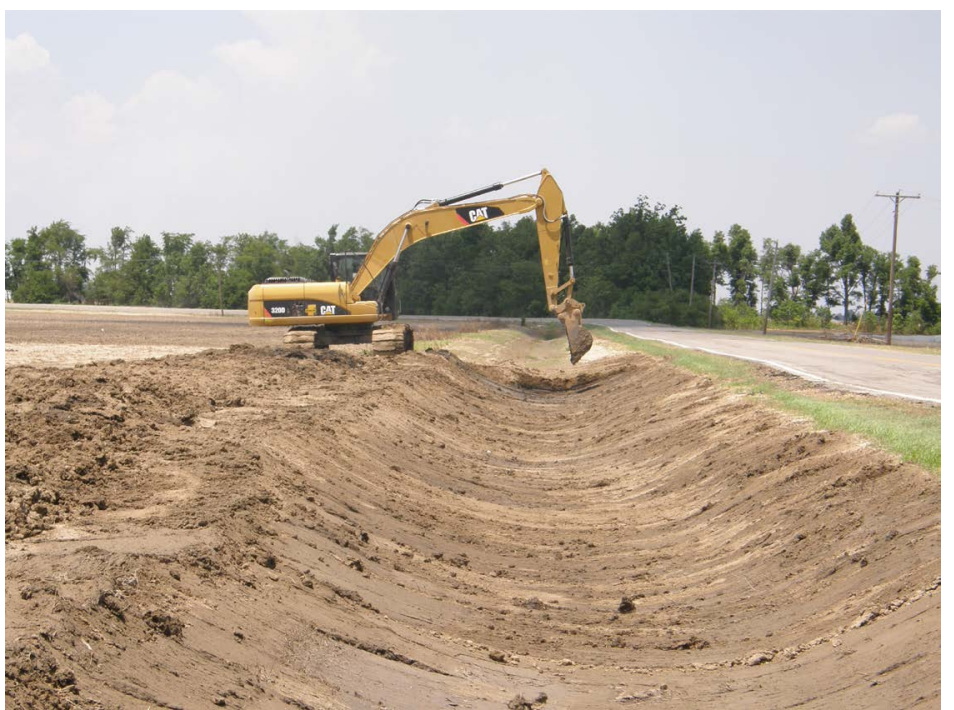

Figure 31. Cleaning ditches road ditches after the flood of 2011 and opening of the New Madrid floodway.

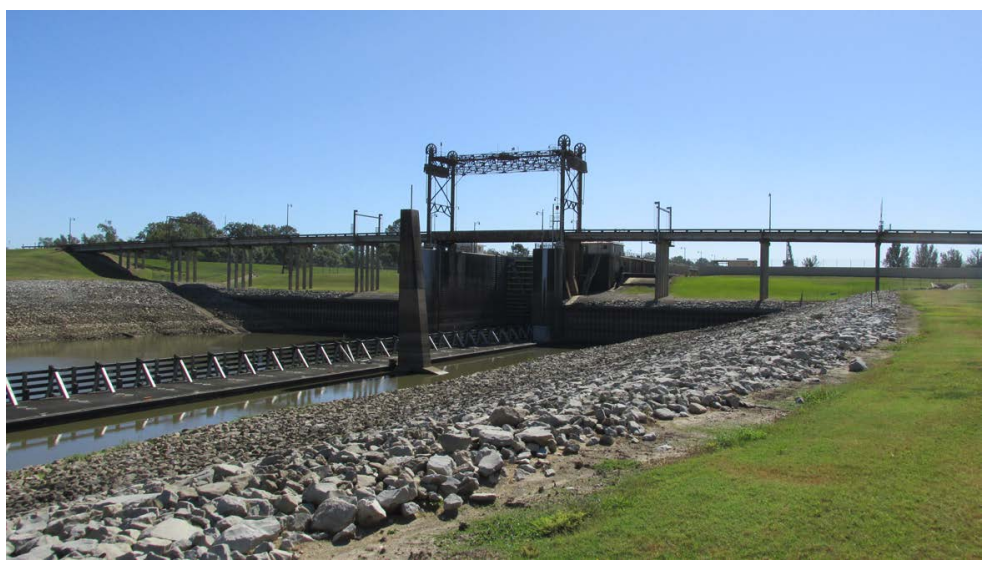

Figure 32. Old river control complex waterway. 
through the use of cutoffs (severing large beds from the river), confining the improved carrying capacity of the main channel and corrective dredging [21]. Between 1932 and 1942, the MRC executed 15 artificial cutoffs that along with one natural cutoff, chute enlargement and other corrective dredging techniques, reduced, the length of river by nearly $272 \mathrm{~km}$ and achieved stage reductions in the project flood line by up to $4 \mathrm{~m}$ [22]. The second key component of the Old River control complex (Figure 33) was the 1954 construction of the complex at the head of the Atchafalaya River basin to prevent the Atchafalaya River from capturing the Mississippi River floodwaters, thus completing the design to route $30 \%$ of flow (Figure 34) to the Atchafalaya River.

Approximately $48 \mathrm{~km}$ below Old River complex on the Mississippi River is the Morganza floodway. The $1190 \mathrm{~m}$ long structure with 125-bays intake can divert up to $16,990 \mathrm{cu} \mathrm{m} / \mathrm{s}$ from the Mississippi River. The West Atchafalaya floodway extends along (Figure 35) parallels the Morganza floodway to the west side of Atchafalaya River. The floodway has a $13 \mathrm{~km}$ long fuse plug section of levee at its head. When the fuse plug section crevasses or backwater from the Atchafalaya River overtops the levee, the floodway can divert up to $70,790 \mathrm{cu} \mathrm{m} / \mathrm{s}$.

\subsection{Flood Control Act of 1938 and 1944}

One of the most powerful weapons for averting flood disasters and reducing the maximum height of floodwater downstream is the network of reservoirs and dams built on tributaries hundreds of kilometers upstream in the headwaters of the Ohio and Mississippi river basins [4]. The Kentucky Dam built in the 1940s on the Tennessee River (Figure 36), $34 \mathrm{~km}$ upstream from Paducah on the Ohio River, is one of the largest human constructed reservoirs built to store excess floodwater [2].

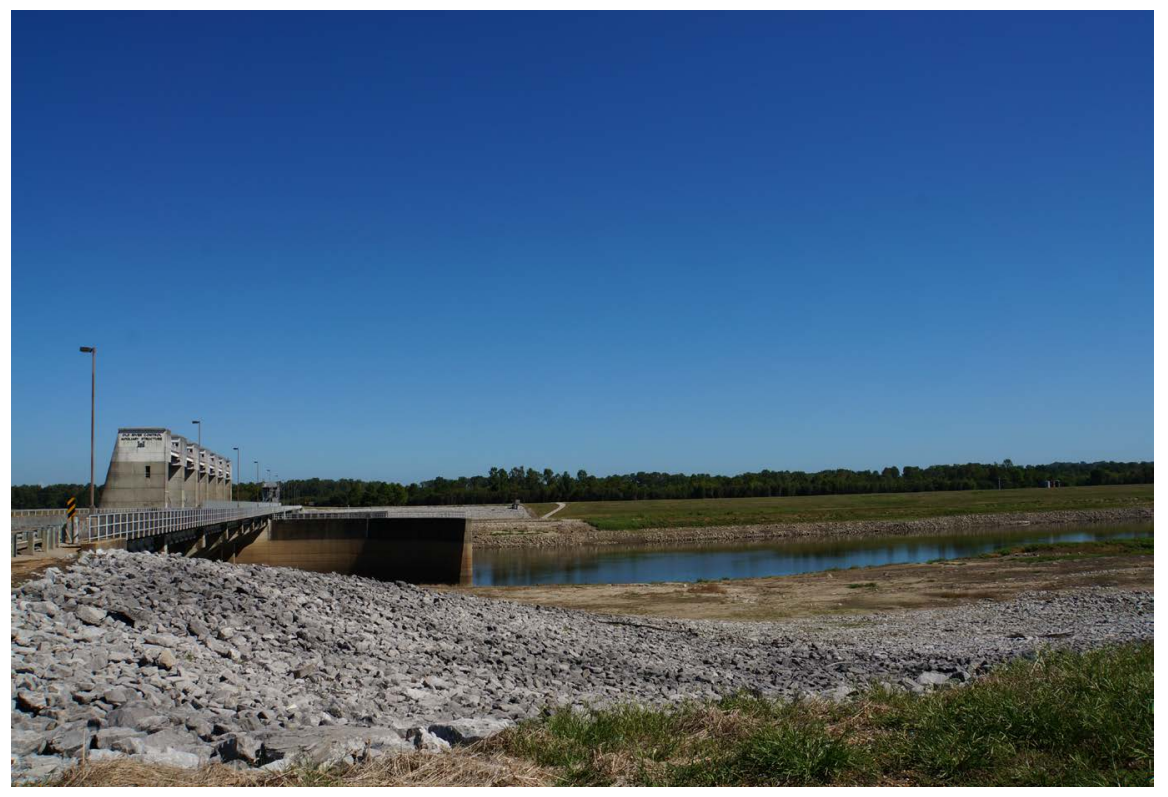

Figure 33. Old river control complex spillway. 


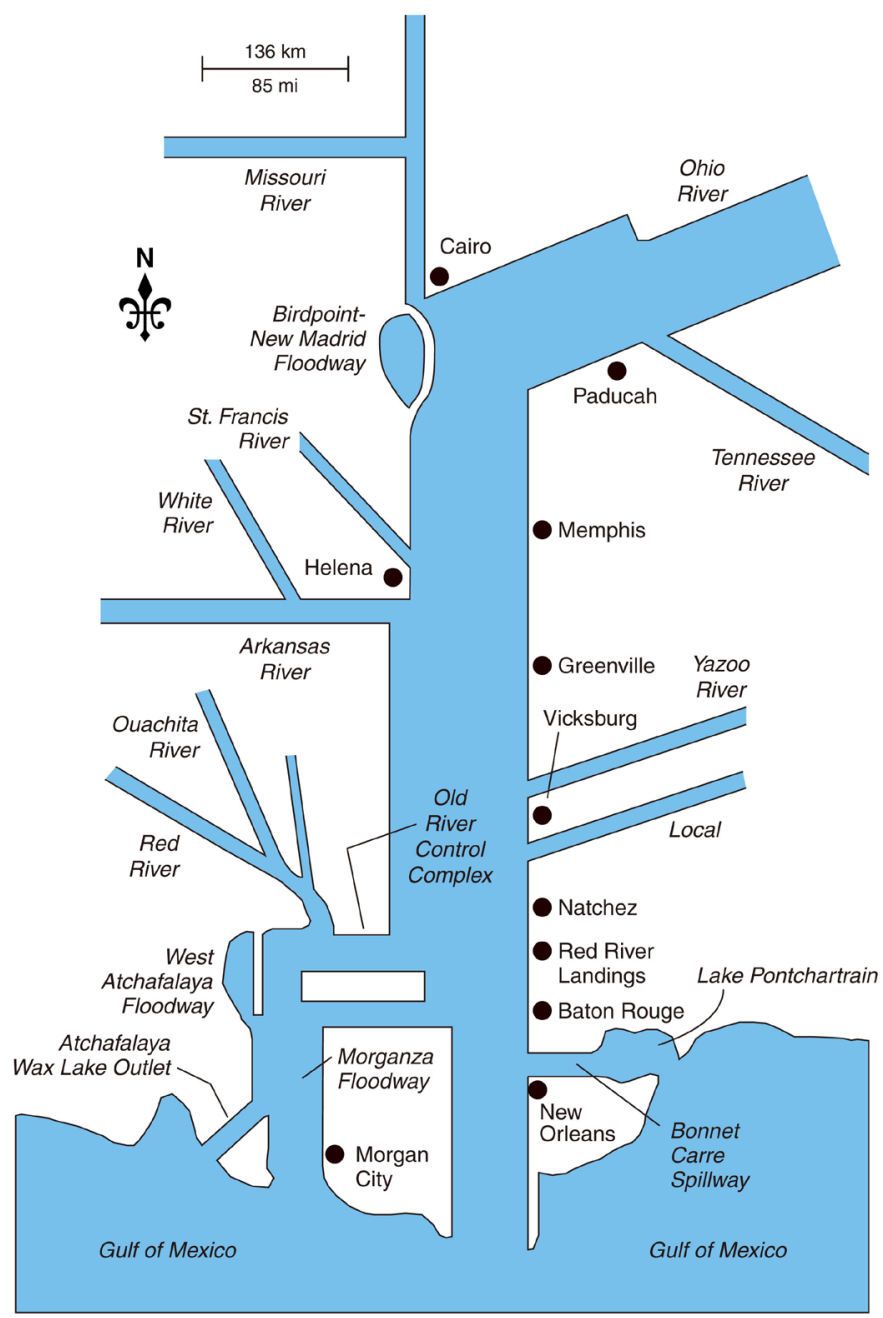

Figure 34. Lower Mississippi River flow rates. Map was modified by Mic Greenberg from the book Divine Providence. The 2011 Flood in the Mississippi River \& Tributaries Project [22].

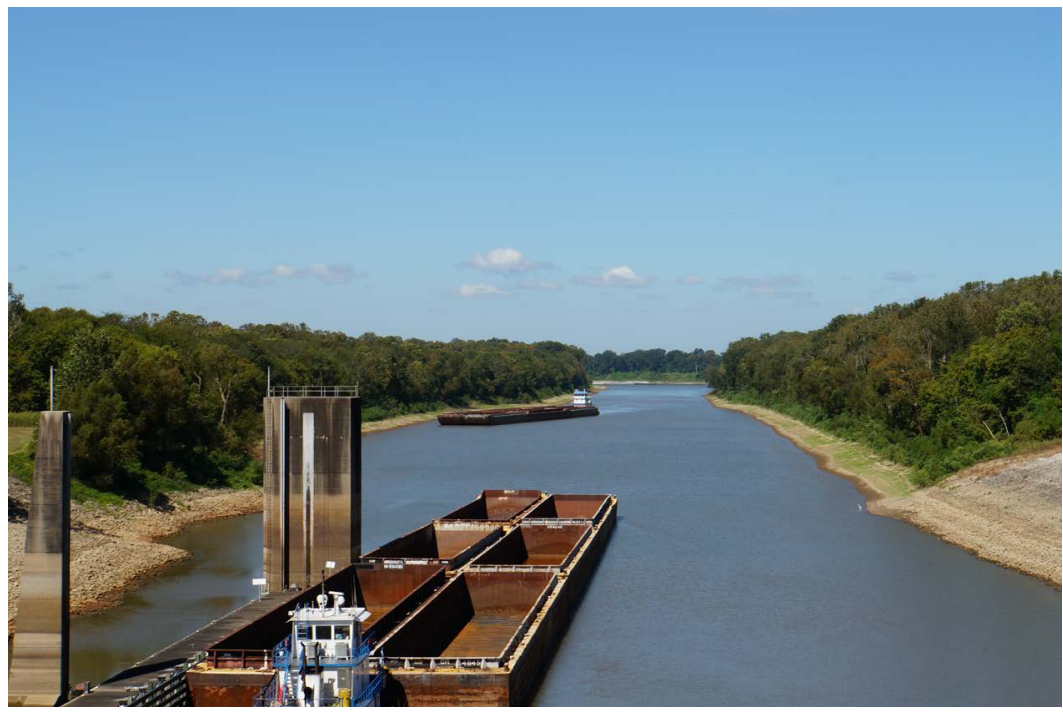

Figure 35. Canal at old river control structure. Photograph taken by Lois Wright Morton. 


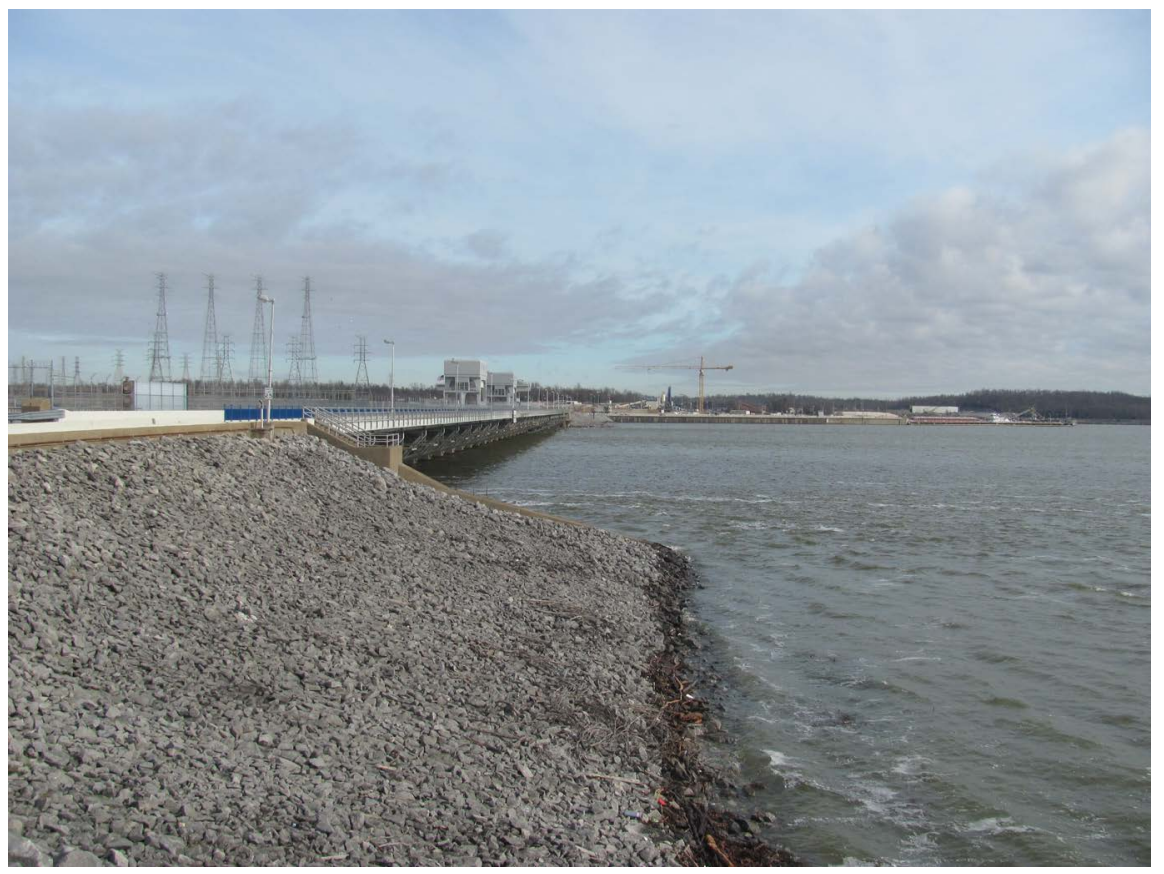

Figure 36. Wide Kentucky dam and reservoir.

The system between Old River control complex and Memphis is supplemented by four backwater areas located at the mouths of the St. Francis, Yazoo, White and Red rivers (Figure 24). Upper sections of these backwater areas receive protection from overflows of the Mississippi River afforded by mainline lower portions which serve as natural storage during larger floods approaching project design capacity. The backwater levees overtop at a time sufficient to reduce project flood peak stages along the main stem of the Mississippi River. When flood stage peaks on the Mississippi River or its tributaries subside, floodwater within the backwater already drains through pumps and floodgates. The Yazoo backwater area has no pumps.

There are four major backwater areas on the Lower Mississippi River (Figure 24). These backwater areas are the result of Mississippi River levee system gaps left at the mouth of tributaries that empty into river [22]. Prior to the construction of levee systems these backwater areas flooded naturally during Mississippi River flooding events. The levee system actually protected the backwater areas from flooding but during flooding events water backed up through the gaps at the lower end of the levee and inundated the low-lying areas behind the levees. The 1928 levee project did not attempt to protect these major backwater areas located at the mouths of White, St. Francis, Red and Yazoo rivers. These low-lying lands stored vast quantities of floodwater, thereby lowering flood stage peaks on the Mississippi River [22].

The initial success of channel re-alignment and rectification program of 1930s improved the ability of the river to carry more water at lower stages. The 1936 Overton Act authorized the building of reservoirs and other improvements on the Yazoo River to protect from headwater floods originating from hill country 
in Yazoo basin. From the Red River backwater to the Gulf of Mexico, including Atchafalaya basin, the Mississippi and tributary project is designed to divert and control of the Mississippi River floodwaters [22].

The Ohio River and Mississippi Ohio River confluence has been the most difficult section to control flooding on the entire Mississippi and Ohio River basins. The severity of flooding problems at the confluence increased after the low gap of Cape Girardeau (old ancient Mississippi River channel) was blocked by farmer levees after 1890 and by a $55 \mathrm{~km}$ long diversion channel and adjacent levees by 1915 [26]. This resulted in an increase in the peak flows between Cape Girardeau and Helena, Arkansas. Historically during major floods, the Mississippi River naturally overflowed into the Ancient Mississippi River channel and then flowed into the Big Swamp (Missouri Boothill) (Figure 37). Up to 84,950 cu m/s [22] flowed through the low gap at Cape Girardeau and into the Big Swamp which then drained to the Little River and St. Francis River basins before flowing into the Mississippi River near Helena, Arkansas (Figure 38 and Figure 39). This natural ancient Mississippi canal and gap lowered the Mississippi River peak flow between Gape Girardeau and Helena a distance of more than 350 river miles prior to the 1890s farmer levee construction and the later 1915 diversion embankment and channel (Figure 40 and Figure 41).

\subsection{Impact of Encroachments in the New Madrid and West Atchafalaya Floodways}

The West Atchafalaya floodway (Figure 42 and Figure 43) is the last feature of the flood control system under the project design flow installed to mitigate flood damage; however, it was not used during the Flood of 2011. The Atchafalaya River, the West Atchafalaya floodway and the Morganza floodway (Figure 44

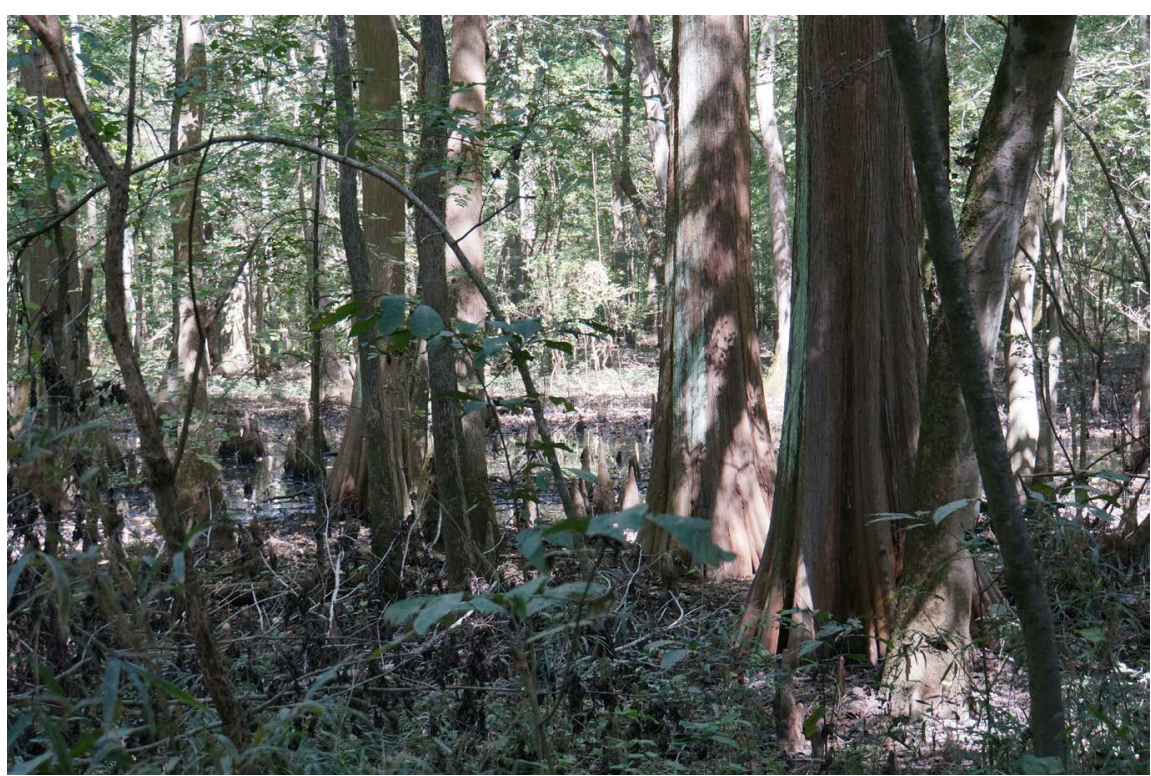

Figure 37. Bald cypress swamp on lower Mississippi River. Photograph taken by Lois Wright Morton. 


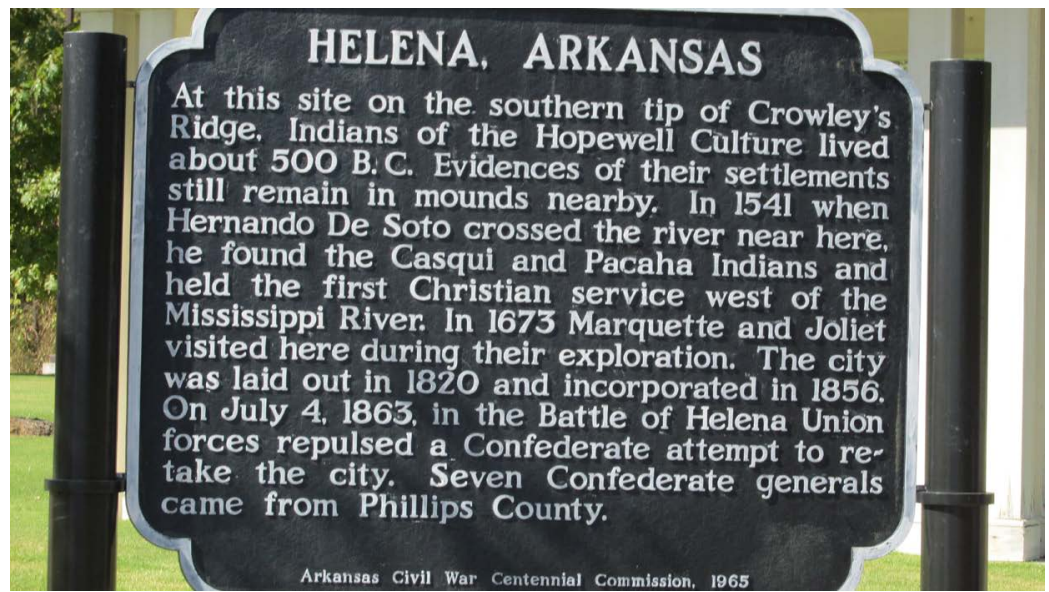

Figure 38. Helena descriptive plaque detailing the cities rich history.

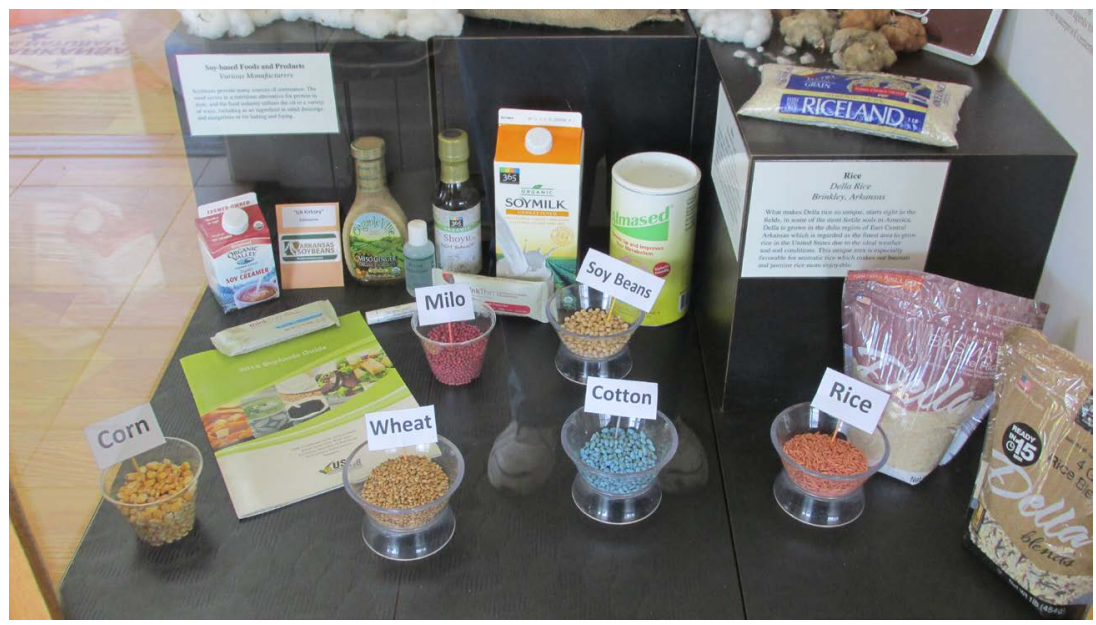

Figure 39. Arkansas and Mississippi River valley agriculture products. Photograph taken by Lois Wright Morton.

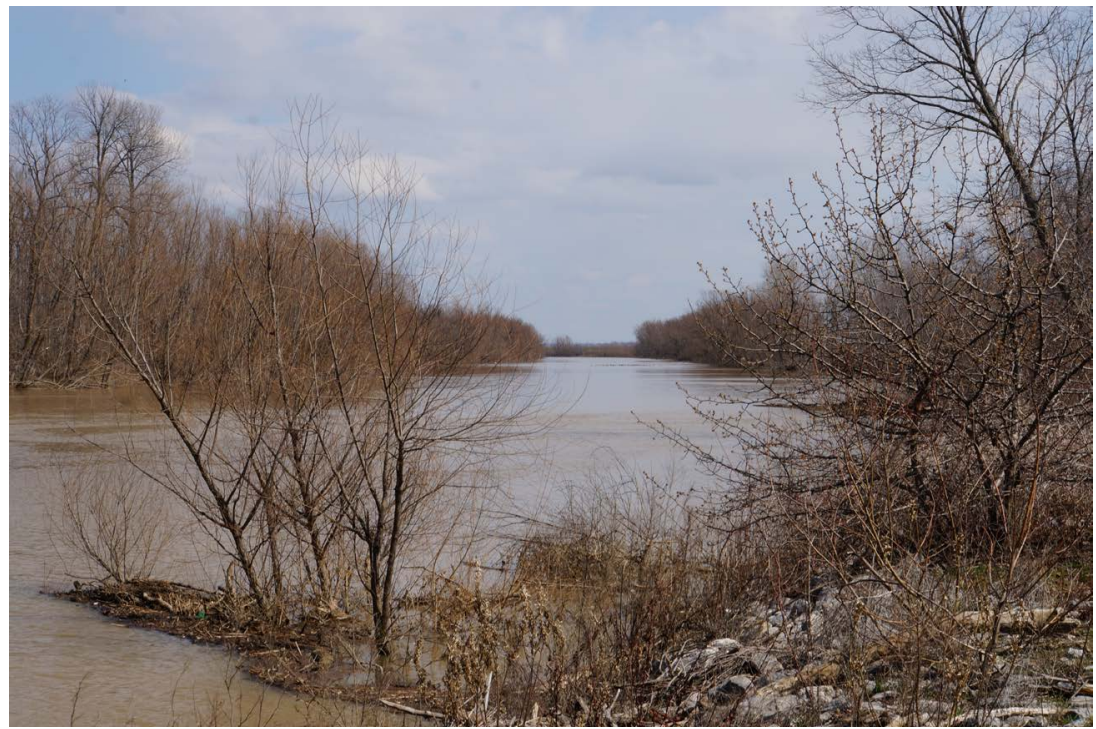

Figure 40. The Little River drainage district headwater diversion channel. Published with copyright permission from Book Editor of Soil and Water Conservation Society. 


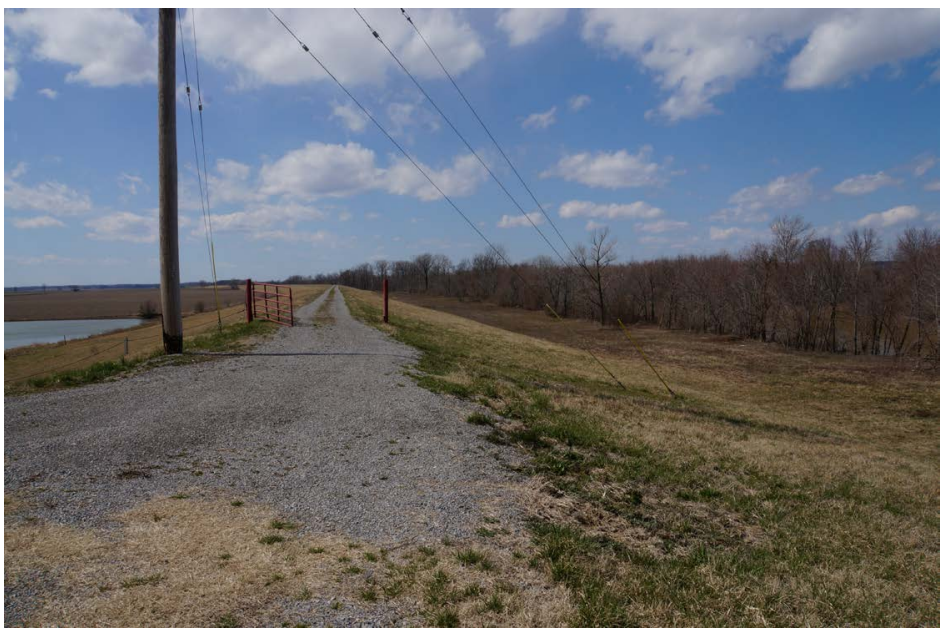

Figure 41. The Little River drainage district diversion embankment. Published with copyright permission from Book Editor of Soil and Water Conservation Society.

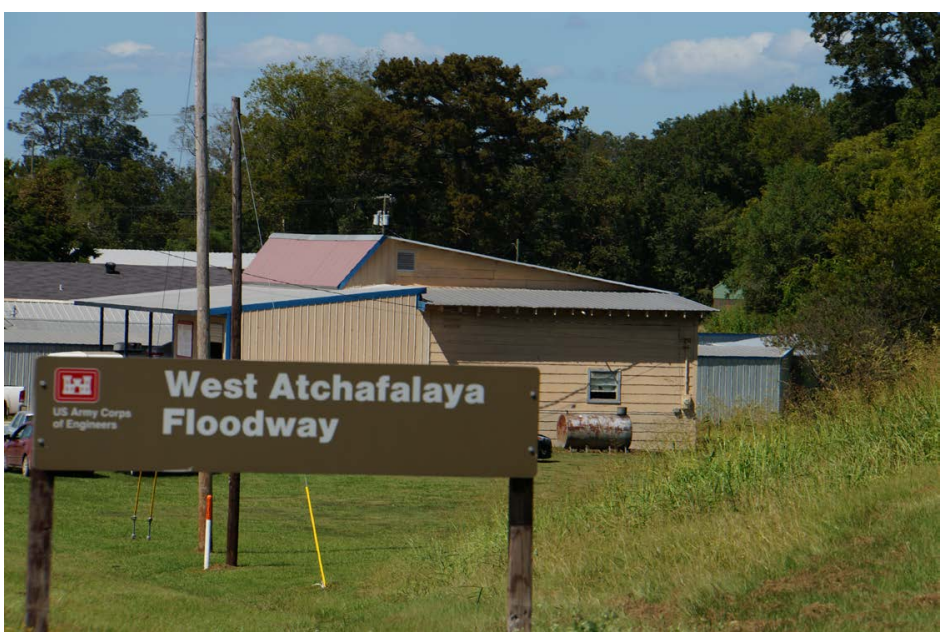

Figure 42. West Atchafalaya floodway sign with protected structures and levee in background.

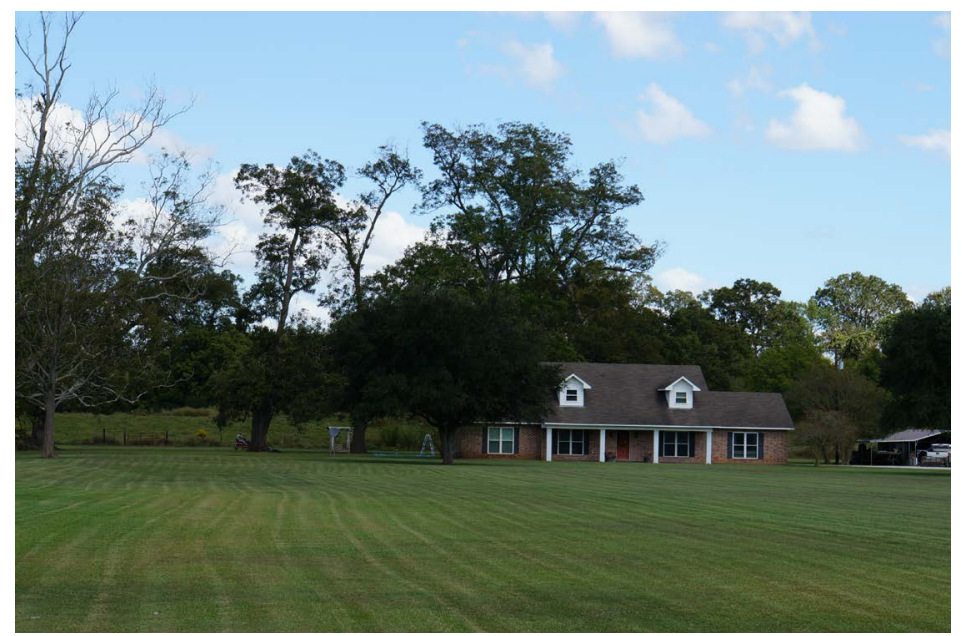

Figure 43. The West Atchafalaya floodway levee protecting a newly constructed home. Photograph taken by Lois Wright Morton. 


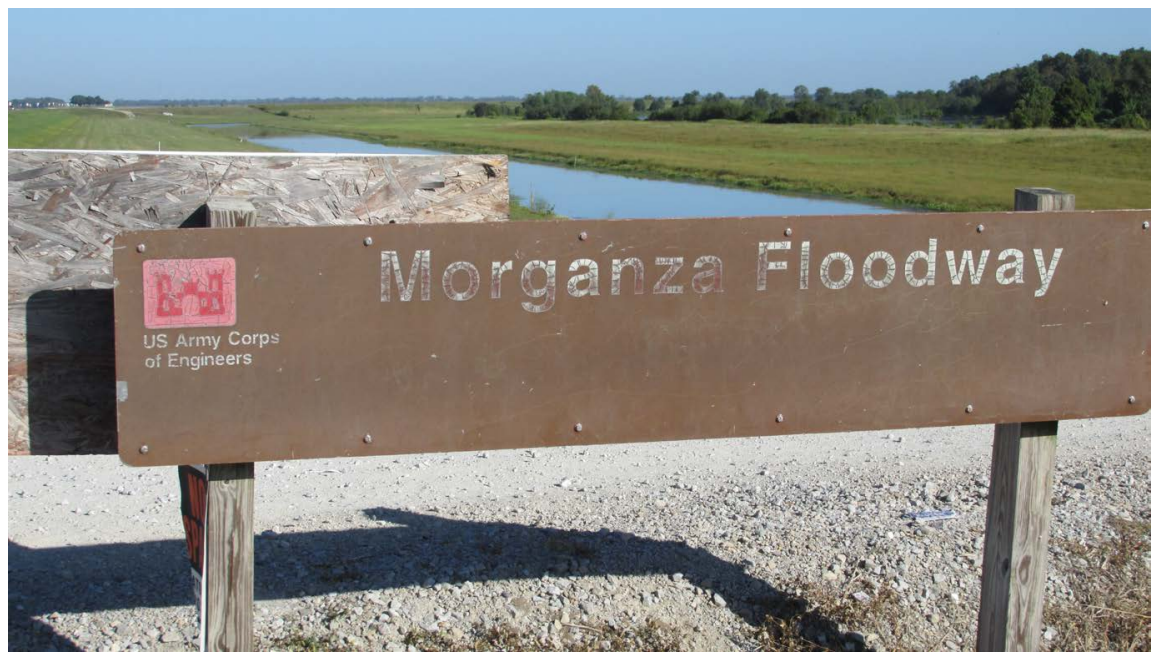

Figure 44. Morganza floodway sign.

and Figure 45) and converge to form the Atchafalaya basin floodway at the lower end of the Atchafalaya River levee. This floodway is designed to carry 42,475 $\mathrm{cu} \mathrm{m} / \mathrm{s}$ or nearly one-half of project flood discharge of $84,950 \mathrm{cu} \mathrm{m} / \mathrm{s}$ at Red River Landings including flows through the Old River control structures [21]. Flowage, $84,950 \mathrm{cu} \mathrm{m} / \mathrm{s}$, can be discharged into the Gulf of Mexico with almost one-half going through Atchafalaya 33,980 cu m/s and passing through Way Lake Outlet. The other $42,475 \mathrm{cu} \mathrm{m} / \mathrm{s}$ remains in the Mississippi River channel with $7079 \mathrm{cu} \mathrm{m} / \mathrm{s}$ passing through the Bonnet Carre Spillway and floodway to Lake Pontchartrain and 35,396 cu m/s passing through Mississippi River at New Orleans. Bonnet Carrie was reaching capacity on May 15, 2011 when opened. The Bonnet Carre Spillway (Figure 46 and Figure 47) has been opened 13 times in eighty years, three in the past decade including the 2011 flood.

Morganza floodway was opened in 2011. The entire structure vibrated from the sudden surge of water as the gantry crane lifted the first gate. The torrent of water unleashed its energy into and across the shallow silt basin before beginning to flow slowly across the dry land and dissipating its power after disappearing into timbered wetlands. There were about 2500 people in the direct path of this spillway, and another 22,500 others threatened by swollen backwaters. The damage to the floodway was much less than anticipated as a result of the control release of water and the land use (timberland and wetlands rather than cropland) immediately to the west and south of the Morganza dam (Figure 45).

\subsection{Land Use Change in West Atchafalaya Floodway}

Encroachment, such as new buildings and other floodway structures, can jeopardize the proper floodway functioning and compromise the functions of the entire system [31]. The Birds Point-New Madrid and the West Atchafalaya floodways, the two largest in the Mississippi River and tributaries system, did not have a comprehensive study of the impact of encroachments. The operation of the Birds Point-New Madrid floodway during the 2011 flood was impacted by 


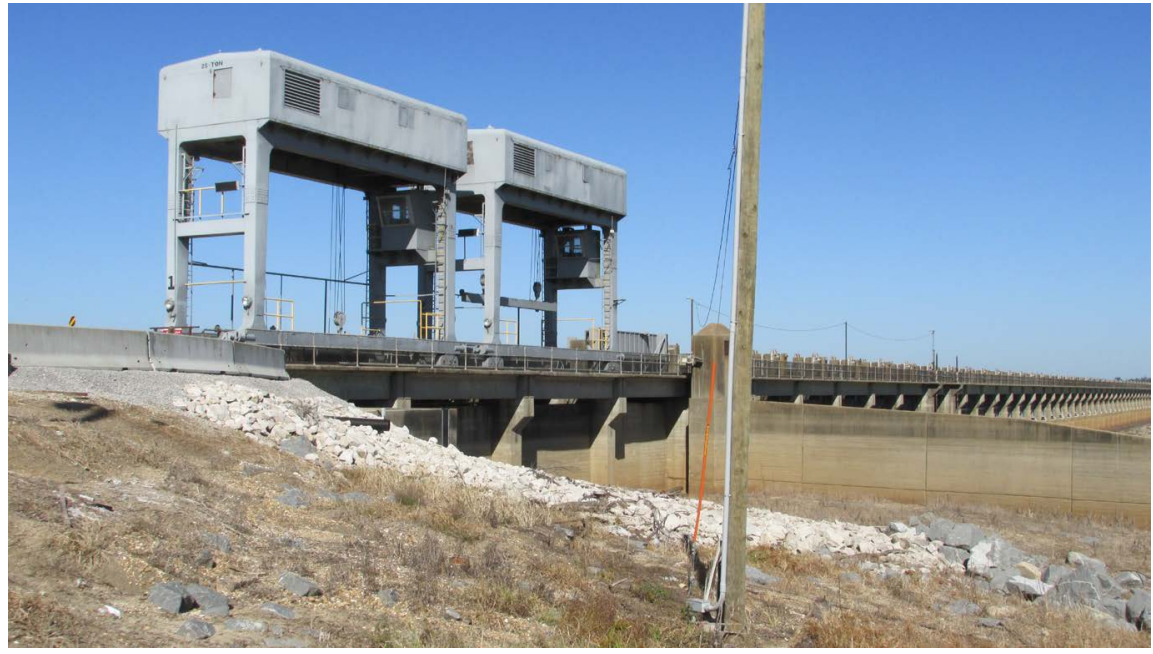

Figure 45. Morganza floodway gate. Photograph taken by Lois Wright Morton.

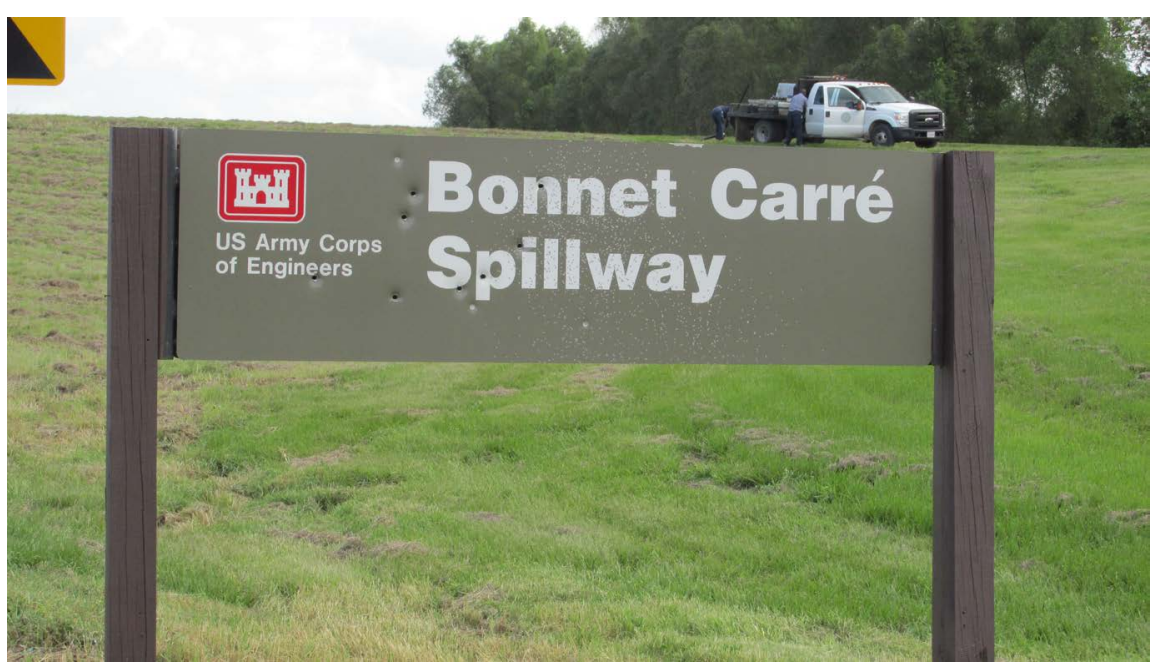

Figure 46. Bonnet Carre Spillway sign.

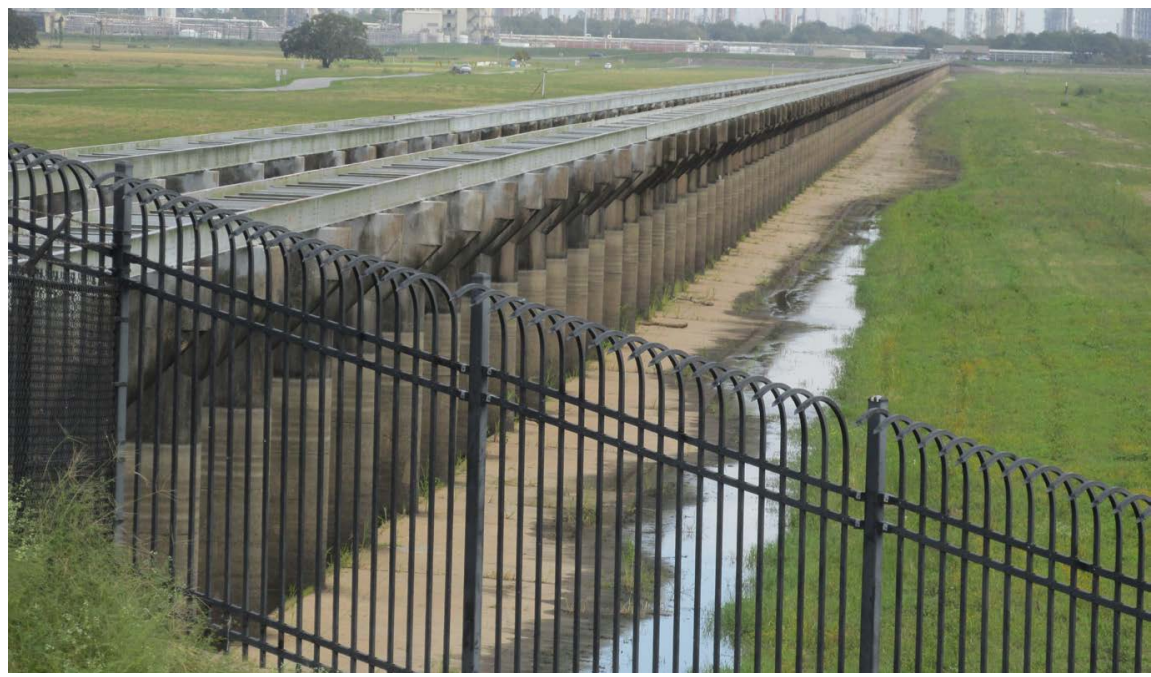

Figure 47. The Bonnet Carre spillway between Mississippi River and the Lake Ponchartrain. 
encroachments and farm landowner resistance. Since the West Atchafalaya floodway has yet to be used therefore the disaster consequences to residences (Figure 42 and Figure 43) living in the West Atchafalaya floodway are unclear and require study. Using aerial imagery and historical maps Lopez-Llompart and Kondolf [32] systematically measured the type, number, and spatial distribution of encroachments in the two floodways after the late 1960s. Encroachment in the Birds Point-New Madrid floodway decreased by one-half, while the number of encroachments in the West Atchafalaya floodway tripled, mainly concentrated along highways and adjacent to the levees. These encroachments created linear bands of higher hydraulic resistance [32]. The presence of encroachments clearly discourages operation of the floodways for their designed purpose. There are no known studies that have determined whether the presence of these structures would adversely and measurably affect flood hydraulic thorough the floodways.

\subsection{Impact on People Residing in Floodways}

The science of understanding the impacts of management of flooding is more than the calculations of flow rates, number of structures and levee lengths. The social, economic and political science on the impacts of well-planned and implemented policies on economic use, property and life protected versus the consequence of poorly implemented policies also needs study.

The consequence of choosing to live in the Birds Point-New Madrid floodway in 1937 resulted in at least three direct known deaths, two flood related deaths and 30 post flood repairmen deaths, an unknown number of homes lost, 4000 acres of farmland destroyed by sand dunes, erosion and gullies and 12,000 displaced persons living in Red Cross Camps and given relief of \$18 per month until they had income from their next crop harvest. In 2011 there was not any deaths, but few residents have returned and rebuilt [33].

The flood of 1937 apparently caused the Sharecroppers Demonstration of 1939 (Figure 48). Some credence can be given to this claim since the two highways, where 1500 evicted tenant farmers and their families camped for four January, 1939 nights, are in or just outside of the floodway. However, farm policies of the Agriculture Adjustment Act (AAA), in the early thirties purposed to eliminate suffering with direct payments to farm tenants, are also implicated. These farm AAA programs, implemented during depression era of low commodity prices and low wages, enabled landowners to employ day labors utilizing new mechanization practices were able to claim the federal payments when tenant contracts were not renewed. On January 1, 1939 thousands of tenants in Southeast Missouri were evicted. Over the course of four years the roadside demonstrators were moved to nine local encampments and later, by 1943, settled in four federal sponsored communities.

The town of Pinhook, an African American community located in the Birds Point-New Madrid floodway was impacted during the 2011 flood [34]. They started farming in the floodway in 1943. Later, in the 50's, they purchased lots in Pinhook. The USACE [35] under the 1928 Flood Control Act, had purchased 


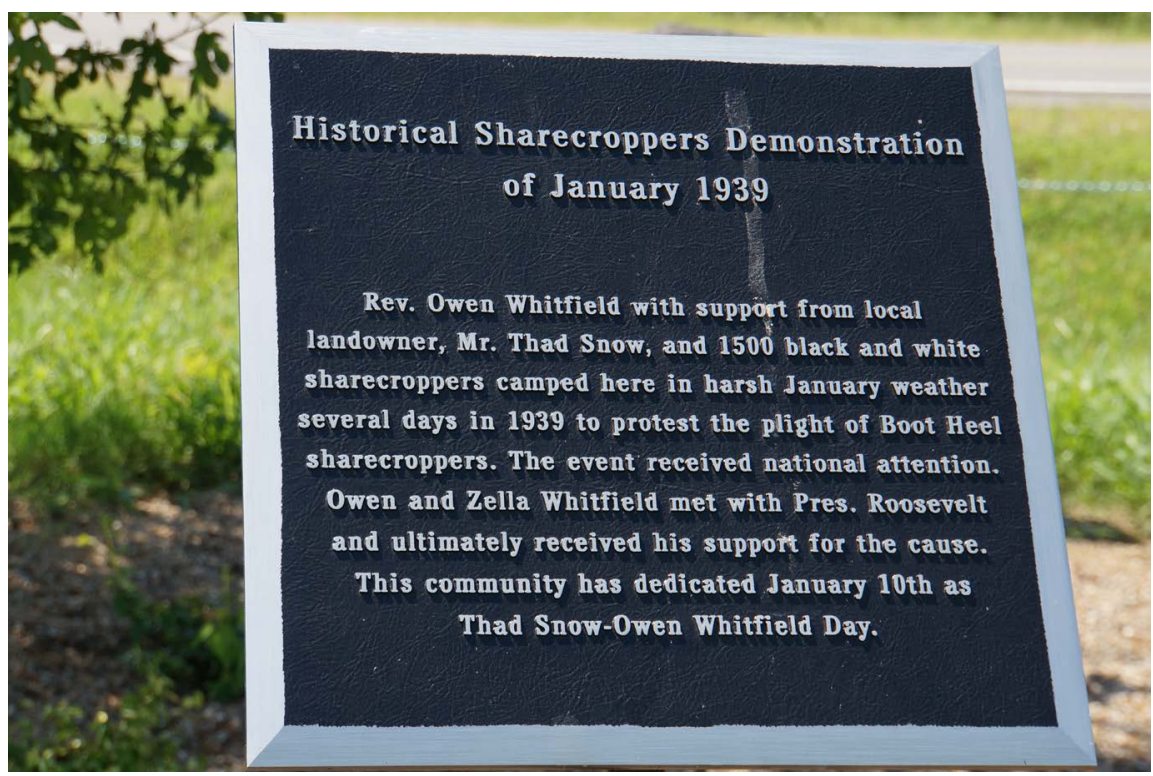

Figure 48. Historical sharecropper demonstration of January 1939 monument and plaque. Photograph taken by Lois Wright Morton.

flowage easements in the floodway with a one-time indemnity average payment of $\$ 17$ per acre. This payment, completed by 1942, was to the landowners. Tenants would have not received the payment and when farming or purchasing land in the floodway and they may not have understood the implications. The original USACE floodwater dispersion plan estimate was to use the floodway every ten years. In 1956 and 1965 the levee elevations were raised, decreasing the projected floodway use to every 17.5 and 80 years respectively. With the number of conflicting policies; indemnity payments only to landowners, farm program payments that landowners could manipulate away from the tenants, raising the levees to reduce floodway use, the floodway residents may not have understood the potential of flooding. The Pinhook community is now abandoned. Only one residential home remained. After seven years, eight of the 16 households resettled into neighboring towns [36].

The West Atchafalaya levee is the last floodway to be used during a major flood event. It is opened by natural levee overtopping. During the Flood of 2011 the West Atchafalaya floodway was not needed. Consequently the recent new encroachments, three times the number as in the New Madrid floodway, were spared damage.

\subsection{River Training Program}

The USACE has developed a river training program which has resulted in more than 13,000 structures being built (Figure 49) on the Mississippi and Missouri rivers. These include wing dams or dikes and bendway weirs (Figure 50). The rivers were shortened and the alignment stabilized with bendway weirs on the bends consisting of rock ridges under water with wind dams or dikes consisting of rock laid perpendicular to the shore line and showing above the water line 


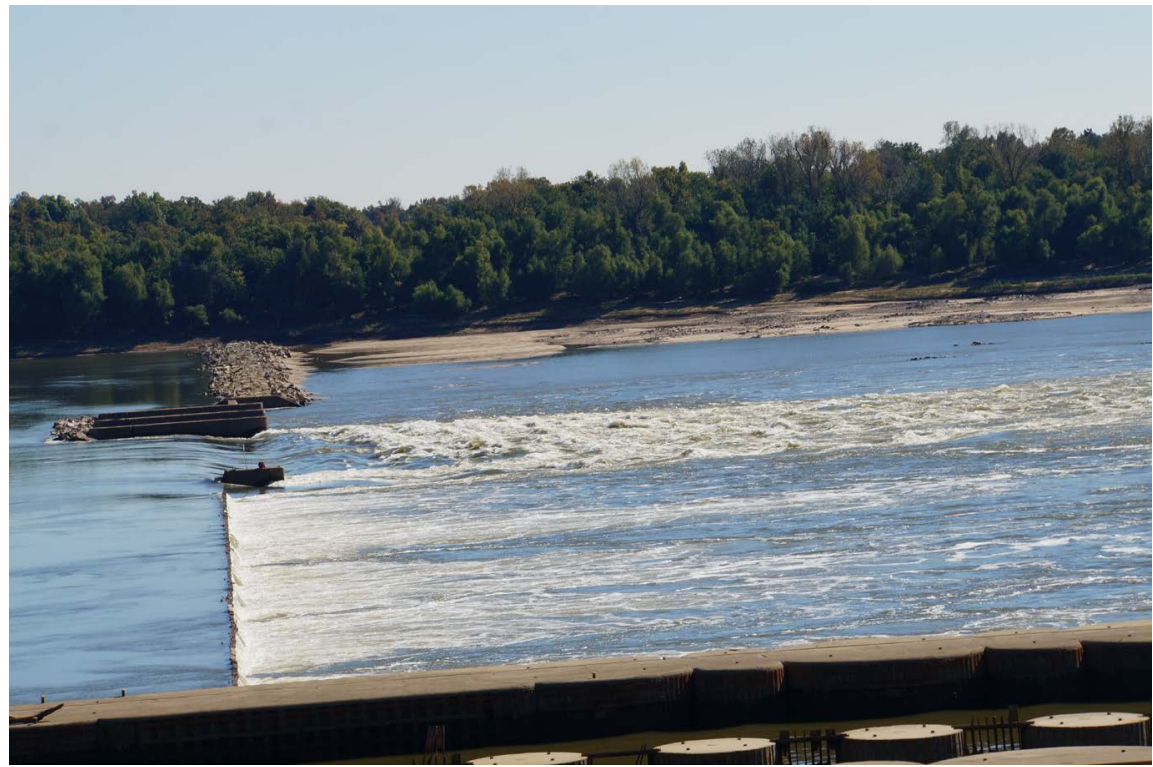

Figure 49. Dikes and dams on the Lower Mississippi River and tributaries.

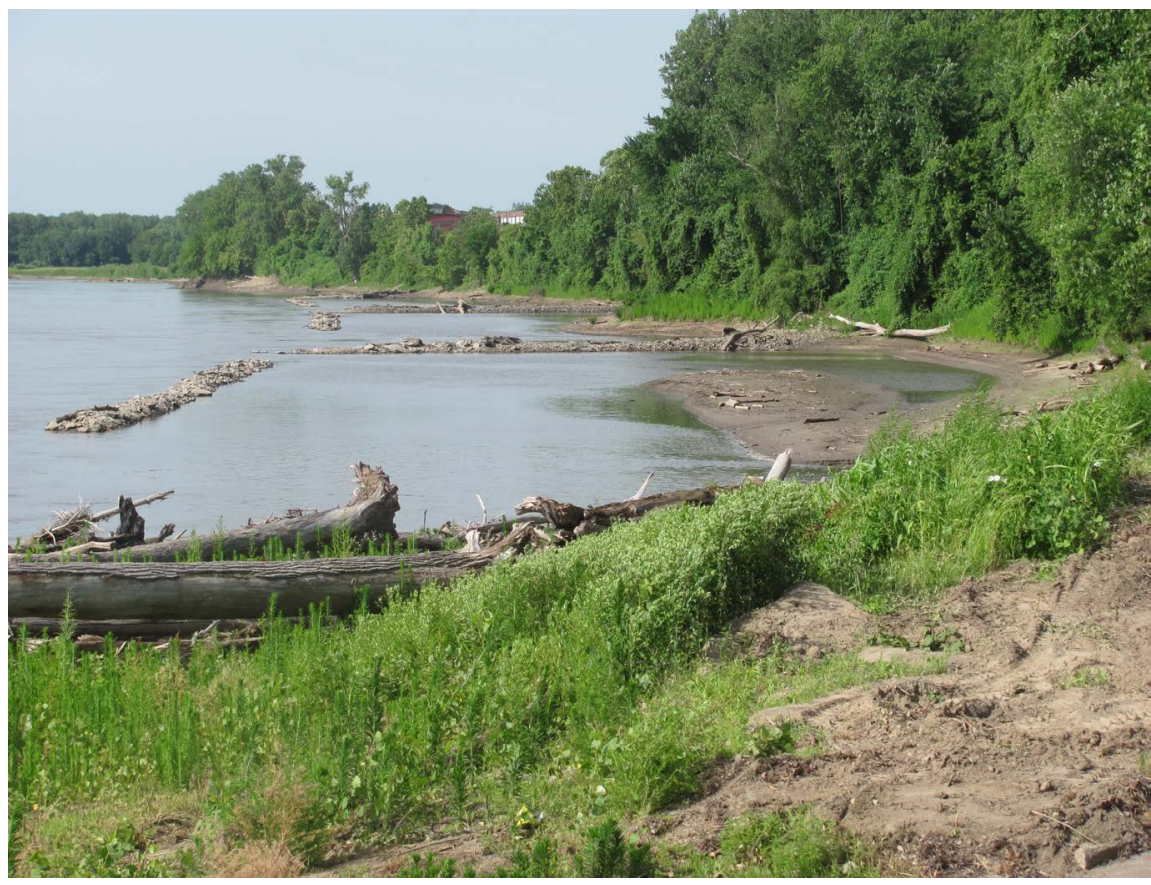

Figure 50. Weirs on the Lower Mississippi River and tributaries.

when the rivers were not above flood stage. The use of weirs to maintain the channel location on river bends are thought to keep sediment in suspension rather than being deposited in the river channel and requiring dredging.

\section{Summary}

Since 1717 strategic navigational control of the mouth of the Lower Mississippi River has been the goal of at least three European nations and the United States. Initially France won. However, their claims were continually challenged by Spain. 
In 1803 France sold its claim to the Mississippi River Delta and strategic navigational control of the Mississippi River to the United States. However, Spain, which claimed to control land west of the Mississippi River continued to object. When the Louisiana Purchase was being negotiated the French offered to sell the Missouri River Valley in addition to the Lower Mississippi River Valley in the deal for more than the amount that United States originally offered to pay. The US accepted the offer and for \$15 million United States got strategic navigational control of the Lower Mississippi River and the claim to the Lower Mississippi River Valley and the Missouri River Valley lands. President Jefferson who as eager to explore and claim the Missouri River Valley had already sent Lewis earlier in 1803 on his mission to find the Northwest Passage. President Jefferson insisted that Lewis and Clark stay on the Missouri River which made getting through the Rocky Mountains to the Pacific Ocean much more difficult. While acquiring the Missouri Valley lands was important to a young United States, since it doubled the size of the country, the strategic navigational control of the Mississippi River and ability use it for trade was more important. The American Civil War (18611865) was partly a Lower Mississippi River battle via gunboats to strategically control trade and access to world markets. The port of New Orleans was captured in May 1862. While many sea ports did have blockade runners until 1863, the river was open to Union trade in 1863. This vital Lower Mississippi River trade route was re-opened in 1865 and remained under the control of the Union to this day.

The dominant land use in the Lower Mississippi River landscape has remained in agriculture (Figures 51-55). The Mississippi River Commission had a levees-only policy until after the Flood of 1927. In May of 1927, while the Great Flood was still happening, Major General Edgar Jadwin instructed the agency to modify the policy. Backwater areas, channelized rivers, levees and floodwalls

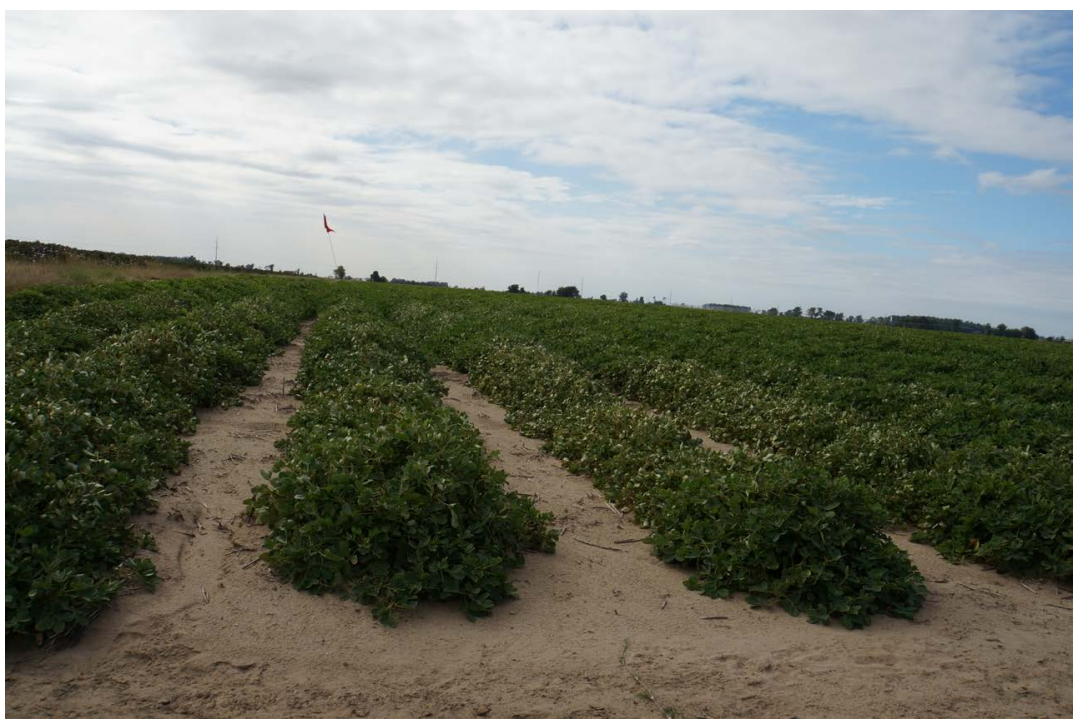

Figure 51. Peanuts being grown on the Lower Mississippi River. Photograph taken by Lois Wright Morton. 


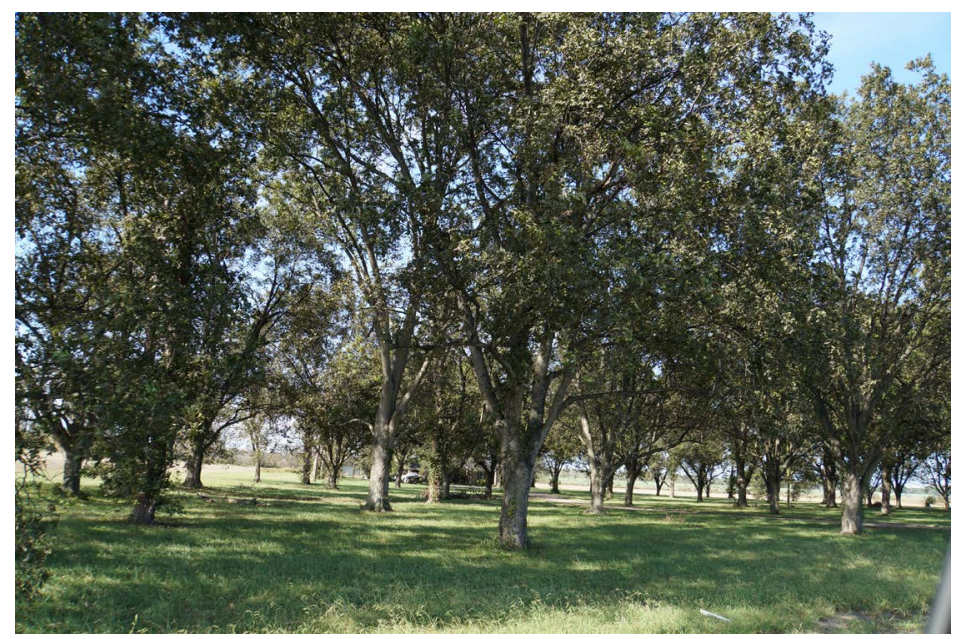

Figure 52. Pecan trees grown in the alluvial soils of the Lower Mississippi River. Photograph taken by Lois Wright Morton.

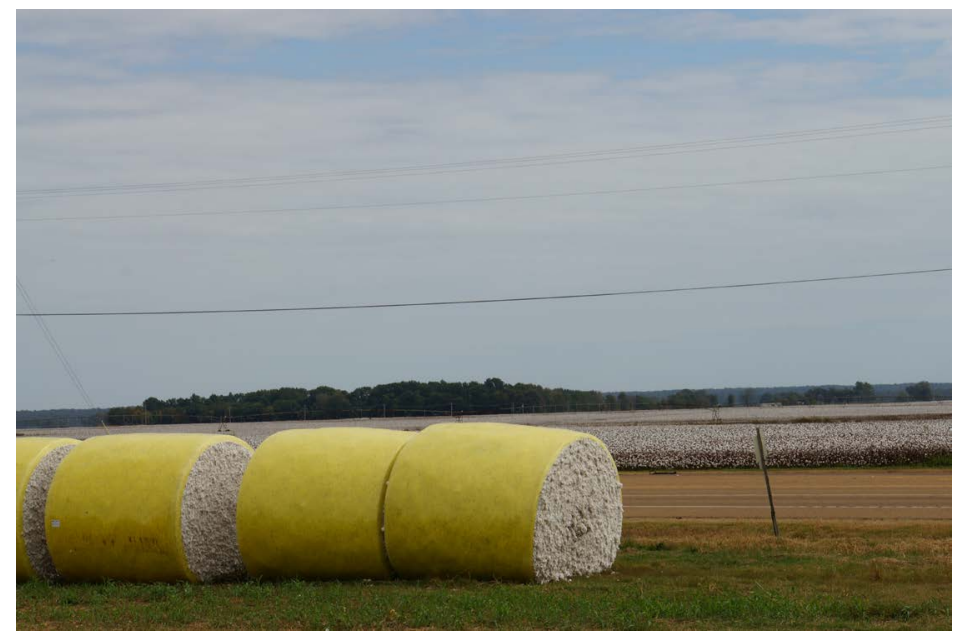

Figure 53. Cotton field ready for harvest and cotton bales already harvested. Photograph taken by Lois Wright Morton.

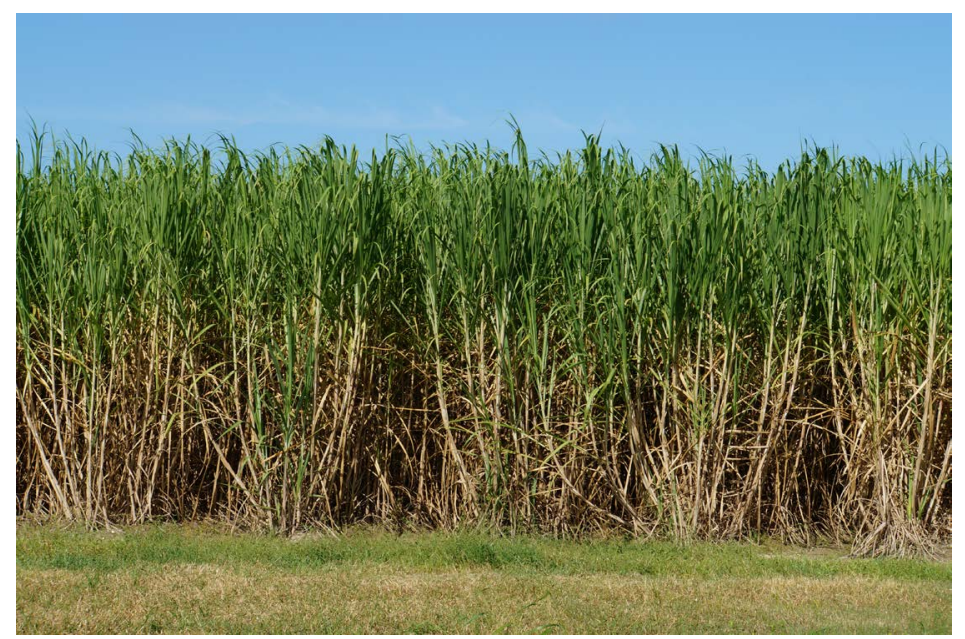

Figure 54. Sugarcane fields west of the Mississippi River near Baton Rouge. Photograph taken by Lois Wright Morton. 


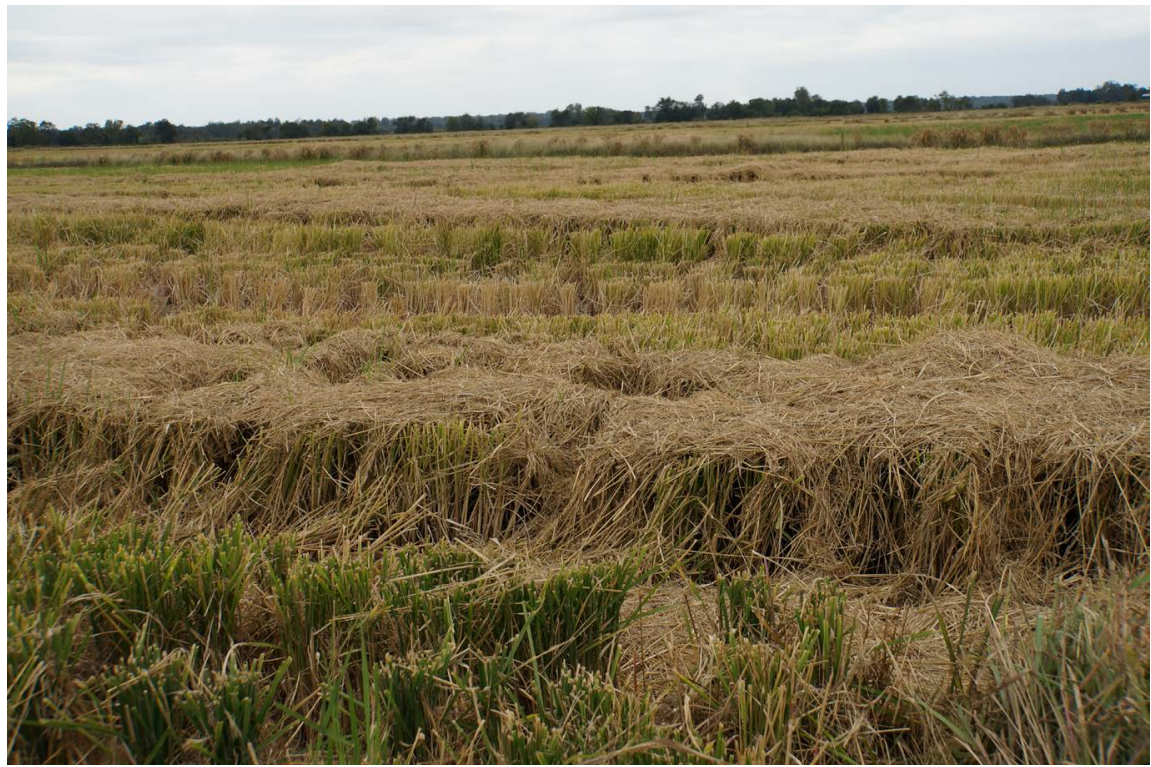

Figure 55. Rice field in Arkansas which is still green after a fall harvest.

(Figure 24), floodways, aqueducts and an extensive system of reservoirs have been created to manage these rivers for navigation and to protect agriculture, communities, and other high value land uses. Navigation on the Lower Mississippi River does not require locks and dams. The West Atchafalaya floodway is the last feature of the Old River flood control complex to be used under the project design flow, the West Atchafalaya was not overtopped, breached, needed or used during the record Flood of 2011.

\section{Conclusions}

The location of the mouth of the Mississippi River allowed the Delta area to become the Gateway to the United States. In 1519 Alvarez de Pineda of Spain discovered the Mississippi River Delta. In 1682, Robert Cavelier de La Salle claimed the Mississippi River Delta for France. In 1699 the French built the first fort at La Balize on Southeast Pass in Pass a Loutre to strategically control navigation from the Mississippi River into the Gulf of Mexico. In 1803, the US acquired New Orleans, located near the mouth of the Mississippi River, which allowed free passage of the United States ships into the Gulf of Mexico and the Atlantic Ocean. A $\$ 15$ million land acquisition from the French, known as the Louisiana Purchase, included 2,144,000 ha of land located in the Mississippi and Missouri River Valleys. The Mississippi River was once again open for United States commerce to reach the Gulf of Mexico. During the Vicksburg campaign for navigational control of the Mississippi River, almost 3000 Union and Confederate soldiers were killed and approximately 10,000 soldiers were wounded a rather high price to pay to maintain strategic navigational control of a major trade route, the Mississippi River. Navigation and trade on the Mississippi River increased after the Civil War, and this economic development eventually moved into the Delta. 
The MRC/USACE employed a variety of engineering techniques to control flooding on the Lower Mississippi River and to maintain the shipping channel. The primary approach prior to 1927 was to build levees on all bottomland areas adjacent to the Lower Mississippi River. The key Mississippi River Commission/USACE flood control and navigation practice was a system of levees that were completed in 1926. A spokesman for USACE claimed the flooding on the Lower Mississippi River was now under control. By January of 1927, the rivers began to rise and the worst Lower Mississippi River flooding event ever ensued. The MRC/USACE changed their strategy, dropping the levees-only policy to include the river management with the creation of four storage areas and four floodways on the Lower Mississippi River (Figure 24). This new management approach started an evolution resulting in the 1936 Flood Control Act later augmented with reservoirs authorized in the Flood Control Act of 1938 which had been obviated in the prior legislation.

During the 1940s and 1960s two huge reservoirs, the Kentucky and Barkley were built to reduce the peak flooding on the Ohio and Lower Mississippi Rivers by storing most of the Tennessee and Cumberland River floodwaters during Ohio River peak flooding times. Since the early 1930s and until the Flood of 2011 the new USACE flood control strategy had been successful without having to open the New Madrid floodway. The combination of reservoirs, water storage areas and floodways were able to handle the major flooding events without the use of the New Madrid floodway until the Flood of 2011. Future major floods will happen. Maintenance of the existing system will be important to ensure the impact of these floods can be handled. Past lessons indicate floodway encroachment, which is now occurring in the West Atchafalaya floodway, can be consequential and significant outreach is still needed to mitigate future property damage and potential loss of life. The strategic navigational and flood control of the Lower Mississippi River and geological and landscape resources were responsible for the successful economic development of the Lower Mississippi River region of North America.

\section{Acknowledgements}

This paper is published with funding support from USDA, NIFA, Water Division, Natural Resources and Environmental Sciences, and with the approval of the Director of the Illinois Office of Research, College of Agricultural, Consumer, and Environmental Science, University of Illinois, Urbana, Illinois.

\section{Conflicts of Interest}

The authors declare no conflicts of interest regarding the publication of this paper.

\section{References}

[1] Olson, K.R. and Morton, L.W. (2013) Soil and Crop Damages as a Result of Levee Breaches on Ohio and Mississippi Rivers. Journal of Earth Science and Engineering, 
3, 139-158.

[2] Morton, L.W. and Olson, K.R. (2019) Securing the Nation's Infrastructure: The Ohio River. Journal of Soil and Water Conservation, 74, 5A-11A. https://doi.org/10.2489/jswc.74.1.5A

[3] Lemmon, E. M., Lemmon, A.R. and Cannatella, D.C. (2007) Geological and Climatic Forces Driving Speciation in the Continentally Distributed Trilling Chorus Frogs (Pseudacris). Evolution, 61, 2086-2103. https://doi.org/10.1111/j.1558-5646.2007.00181.x

[4] Olson, K.R. and Morton, L.W. (2016) Managing the Mississippi and Ohio River Landscapes. Book Division, Soil and Water Conservation Society, Ankeny, Iowa.

[5] Oboh-Ikuenobe, F.E., Spencer, M.K., Campbell, C.E. and Haselwander, R.D. (2012) A Portrait of Late Maastrichtian and Paleocene Palynoflora and Paleo-Environment in the Northern Mississippi Embayment, Southeastern Missouri. Palynology, 36, 63-79. https://doi.org/10.1080/01916122.2012.679208

[6] Hosman, R.L. (1996) Regional Stratigraphy and Subsurface Geology of Cenozoic Deposits, Gulf Coastal Plain, South-Central United States. US Geological Survey Professional Paper 1416-G, US Government Printing Office, Washington DC. https://doi.org/10.3133/pp1416G

[7] Van Arsdale, R.B. and TenBrink, R.K. (2000) Late Cretaceous and Cenozoic Geology of the New Madrid Seismic Zone. Bulletin of the Seismological Society of America, 90, 345-356. https://doi.org/10.1785/0119990088

[8] Olson, K.R., Morton, L.W. and Speidel, D. (2016) Little River Drainage District Conversion of the Big Swamp to Fertile Agricultural Land. Journal of Soil and Water Conservation, 71, 37A-43A. https://doi.org/10.2489/jswc.71.2.37A

[9] Rittenour, T.M., Blum, M.D. and Globe, R.J. (2007) Fluvial Evolution of the Lower Mississippi River Valley during the Last 100 k.y. Glacial Cycle: Response to Glaciation and Sea-Level Change. GSA Bulletin, 119, 586-608. https://doi.org/10.1130/B25934.1

[10] Olson, K.R. and Morton, L.W. (2014) Dredging of the Fracture Bedrock-Lined Mississippi River Channel at Thebes, Illinois. Journal of Soil and Water Conservation, 69, 31A-35A. https://doi.org/10.2489/jswc.69.2.31A

[11] Olson, K.R. Morton, L.W. and Speidel, D. (2016) Missouri Ozark Plateau Headwaters Diversion Engineering Feat. Journal of Soil and Water Conservation, 71, 13A-19A. https://doi.org/10.2489/jswc.71.1.13A

[12] Cremeens, D.L., Darmody, R.G. and George, S.E. (2005) Upper Slope Landforms and Age of Bedrock Exposures in the St. Francois Mountains, Missouri: A Comparison to Relict Periglacial Features in the Appalachian Plateaus of West Virginia. Geomorphology, 70, 71-84. https://doi.org/10.1016/j.geomorph.2005.04.001

[13] Olson, K.R. and Christensen, F. (2014) How Waterways, Glacial Melt Waters, and Earthquakes Re-Aligned Ancient Rivers and Changed Illinois Borders. Journal of Earth Sciences and Engineering, 4, 389-399.

[14] Olson, K.R. and Suski, C.D. (2021) Mississippi River Delta: Land Subsidence and Coastal Erosion. Open Journal of soil Science, 11, 139-163. https://doi.org/10.4236/ojss.2021.113008

[15] Benard, S.K. (2010) Creoles. An Encyclopedia of Louisiana. Louisiana Endowment for Humanties. http://knowla.org/entry/627/

[16] Olson, K.R. and Suski, C.D. (2020) St. Lawrence Seaway: Navigation on Gulf of Saint Lawrence Estuary and the St. Lawrence River. Journal of Water Resource and 
Protection, 12, 672-691. https://doi.org/10.4236/jwarp.2020.128041

[17] Olson, K.R. and Krug E. (2020) The Danube, an Empire Boundary River: Settlements, Invasions, Navigation, and Trade Pathway. Journal of Water Resource and Protection, 12, 884-897. https://doi.org/10.4236/jwarp.2020.1210051

[18] Legends of America Staff (2015) Cairo Illinois Death by Racism. Illinois Legends. https://www.legendsofamerica.com/il-cairo/

[19] Harrison, L.H. (2009) Civil War in Kentucky. The University Press of Kentucky, Lexington.

[20] Lansden, J.M. (1910) (2009) A History of the City of Cairo, Carbondale, IL. Southern Illinois University Press.

[21] Olson, K.R. and Morton, L.W. (2014) Runaway Barges Damage Marseilles Lock and Dam during 2013 Flood on the Illinois River. Journal of Soil and Water Conservation, 69, 104A-110A. https://doi.org/10.2489/jswc.69.4.104A

[22] Camillo, C.A. (2012) Divine Providence. The 2011 Flood in the Mississippi River \& Tributaries Project. Mississippi River Commission, Vicksburg.

[23] Barry, J.M. (1997) Rising Tide. Simon \& Schuster, New York.

[24] Park, J., Seager, T.P., Rao, P.S.C. Convertino, M. and Linkov, I. (2012) Integrating Risk and Resilience Approaches to Catastrophe Management in Engineering Systems. Risk Analysis, 33, 356-367. https://doi.org/10.1111/j.1539-6924.2012.01885.x

[25] Melillo, J.M., Richmond, R.C. and Ohe, G.W. (2014) Highlights of Climate Change Impacts in the United States: The Third National Climate Assessment. US Global Change Research Program. US Government Printing Office, Washington DC. https://doi.org/10.7930/J0H41PB6

[26] Olson, K.R. and Morton, L.W. (2012) The Impacts of 2011 Man-Induced Levee Breaches on Agricultural Lands of the Mississippi River Valley. Journal of Soil and Water Conservation, 67, 5A-10A. https://doi.org/10.2489/jswc.67.1.5A

[27] Olson, K.R. and Morton, L.W. (2012) The Effects of 2011 Ohio and Mississippi River Valley Flooding on Cairo, Illinois Area. Journal of Soil and Water Conservation, 67, 42A-46A. https://doi.org/10.2489/jswc.67.2.42A

[28] Morton, L.W. and Olson, K.R. (2014) Addressing Soil Degradation and Flood Risk Decision Making in Levee Protected Agricultural Lands under Increasingly Variable Climate Conditions. Journal of Environmental Protection, 5, 1220-1234. https://doi.org/10.4236/jep.2014.512117

[29] Wisner, B., Blaikie, P., Cannon, T. and Davis, I. (2004) At Risk: Natural Hazards, People's Vulnerability and Disasters. 2nd Edition, Routledge, London.

[30] Olson, K.R. and Morton, L.W. (2015) Slurry Trenches and Relief Wells Installed to Strengthen Ohio and Mississippi River Levee Systems. Journal of Soil and Water Conservation, 70, 77A-81A. https://doi.org/10.2489/jswc.70.4.77A

[31] Kondolf, G.M. and Lopez-Llompart, P. (2018) National-Local Land-Use Conflicts in Floodways of the Mississippi River System. AIMS Environmental Science, 5, 47-63. https://doi.org/10.3934/environsci.2018.1.47

[32] Lopez-Llompart, P. and Kondolf, G.M. (2016) Encroachments in Floodways of the Mississippi River and Tributaries Project. Natural Hazards, 81, 513-542. https://doi.org/10.1007/s11069-015-2094-y

[33] Schick, A. (2012) Mississippi River Town of Pinhook Struggles to Reclaim Its Community after Levee Break. Missourian, Cape Girardeau, Missouri.

[34] Roll, J. (2010) "Out Yonder on the Road": Working Class Self-Representation and 
the 1939 Roadside Demonstration in Southeast Missouri. Southern Spaces.

https://southernspaces.org/2010/out-yonder-road-working-class-self-representation -and-1939-roadside-demonstration-southeast-missouri/

[35] USACE-Mississippi Division Report (2017) Birds Point-New Madrid Floodway, USACE. Vicksburg, MS.

[36] Speidel, D.R. (2018) Interview: Debra (Roberson) Tarver, Pinhook Community Story. Benton. 